American University Washington College of Law

Digital Commons @ American University Washington College of

Law

Articles in Law Reviews \& Other Academic

Journals

Scholarship \& Research

1987

\title{
Corporate Mergers: Redefining the Role of Target Directors
}

\author{
Mary Siegel \\ American University Washington College of Law, msiegel@wcl.american.edu \\ Jennifer J. Johnson \\ Lewis and Clark College
}

Follow this and additional works at: https://digitalcommons.wcl.american.edu/facsch_lawrev

Part of the Business Organizations Law Commons

\section{Recommended Citation}

Siegel, Mary and Johnson, Jennifer J., "Corporate Mergers: Redefining the Role of Target Directors" (1987). Articles in Law Reviews \& Other Academic Journals. 1201.

https://digitalcommons.wcl.american.edu/facsch_lawrev/1201

This Article is brought to you for free and open access by the Scholarship \& Research at Digital Commons @ American University Washington College of Law. It has been accepted for inclusion in Articles in Law Reviews \& Other Academic Journals by an authorized administrator of Digital Commons @ American University Washington College of Law. For more information, please contact kclay@wcl.american.edu. 


\title{
University of Pennsylvania Law Review
}

FOUNDED 1852

Formerly

American Law Register

\section{CORPORATE MERGERS: REDEFINING THE ROLE OF TARGET DIREGTORS}

\author{
JenNifer J. Johnson† ANd MARY Siegel $\dagger \dagger$
}

\section{INTRODUCTION}

The vast majority of corporate acquisitions involve negotiated transactions. ${ }^{1}$ While issues surrounding hostile takeovers have garnered

† Professor of Law, Lewis and Clark College, Northwestern School of Law. B.A. 1973, Mills College; J.D. 1976, Yale University.

H Professor of Law, American University, Washington College of Law. A.B. 1972, Vassar College; J.D. 1975, Yale University.

* The research for this Article was supported by the research funds of the Northwestern School of Law and the Washington College of Law.

The authors gratefully acknowledge the research assistance of Douglas Gordon, J.D. 1988, Northwestern School of Law; Gail Gearin, J.D. 1988, Northwestern School of Law; Elizabeth Osenton, J.D. 1987, Washington College of Law; and Cory Nass, J.D. 1988, Washington College of Law. The authors also thank Paul Francis and Louis $\mathrm{J}$. Trotter, Jr. for their editorial assistance.

1 A 1984 study concluded that negotiated transactions accounted for over $90 \%$ of the 1,786 acquisitions of publicly-traded companies between 1976 and 1984; only 28\% of the acquisitions during this time period involved tender offers and less than $5 \%$ resulted from hostile tender offers. See W.T. Grimm \& Co., MERGERSTAt Review 1984 , at $90-96$ (1985). The study does not indicate the percentage of friendly acquisitions that were motivated by actual or potential hostile offers, although other evidence indicates that only about $20 \%$ of tender offers inspire a competitive bid. See Leebron, Games Corporations Play: A Theory of Tender Offers, 61 N.Y.U. L. REv. 153, 195 n.144 (1986). Post-1984 statistics indicate a similar prevalence of negotiated transactions and a decreasing number of hostile acquisitions. See, e.g., Austin, Nigem \& Ber- 
enormous scholarly, judicial, and public attention, developments concerning friendly corporate combinations have remained relatively unnoticed. ${ }^{2}$ Despite the apparent lack of attention that they receive, negotiated acquisitions present many complex issues that neither the legislatures nor the courts have adequately addressed. This Article analyzes the current role of corporate directors in merger transactions ${ }^{3}$ and

nard, Tender Offer Update: 1987, Mergers \& AcQuisitions, July-Aug. 1987, at 4950 (analyzing 1986 tender offer activity and concluding that the proportion of hostile tender offers declined sharply in 1986 following a three-year trend). The relative number of negotiated transactions is likely to increase due to innovative tender offer defensive tactics and the recent proliferation of state antitakeover laws that substantially deter hostile acquisitions. See infra note 105.

${ }^{2}$ Certain negotiated acquisitions however, such as mergers utilized to thwart hostile tender offers, have received extensive analysis. See infra note 83 and accompanying text. Moreover, mergers undertaken to freeze-out minority shareholders have drawn significant attention in recent years. See, e.g., Weinberger v. UOP, Inc., 457 A.2d 701 (Del. 1983) (successful suit by minority shareholders against directors who failed to disclose information concerning the correct value of their stock and negotiated a merger that left the shareholders "frozen out"). See generally Borden, Going Private-Old Tort, New Tort or No Tort?, 49 N.Y.U. L. REv. 987 (1974) (discussing the legality of going-private transactions that freeze out public shareholders).

3 The term "merger" is used generically in this Article to refer to corporate combinations or reorganizations that by statute require the approval of the target's directors and shareholders. See infra note 6 (defining target). Such transactions typically include: (1) classical or statutory mergers in which the stock of Corporation $T$ is converted into either the stock of surviving Corporation $A$, cash, or other property; 2) consolidations in which Corporations $A$ and $T$ both disappear into a third corporation; and 3 ) triangle or reverse triangle mergers in which Corporation $A$ creates a subsidiary, then merges the subsidiary with Corporation T. The term "merger," as used in this Article, also includes alternate acquisition techniques to the extent applicable statutes or judicial merger doctrines require shareholder approval. Included among such alternate acquisitions are stock-for-assets combinations, see, e.g., CAL. CORP. CODE $\S 181$ (c) (West 1977) (defining reorganization to include an equity-for-assets exchange), compulsory share exchanges, see, e.g., MODEL Business CoRp. ACT $\S 73$ (1979) [hereinafter MBCA]; Revised MOdel Business CoRP. ACT § 11.02 (1984) [hereinafter RMBCA] (guidelines for compulsory share exchanges), and substantial asset sales, see, e.g., MBCA, supra, § 79; RMBCA, supra, $\S 12.02$ (guidelines for substantial asset sales). This Article does not analyze or evaluate the effect of the various acquisition techniques on shareholders' appraisal rights, nor does it attempt to evaluate the de facto merger doctrine. For a review of the various forms of corporate combinations, see generally W. Cary \& M. Eisenberg, Cases and Materials on Corporations 14441501 (5th ed. 1980).

The merger provisions of the vast majority of jurisdictions are patterned after one of the versions of the Model Business Corporation Act developed and adopted by the Committee on Corporate Laws of the American Bar Association. References in this Article to the MBCA are to the 1969 version of the Act as amended through 1979. In 1984, the Committee on Corporate Laws adopted the Revised Model Business Corporations Act. While only a few statutes have been revised in accordance with the RMBGA, see, e.g., IND. CODE §§ 23-1-17-1 to 23-1-54-2 (Supp. 1987); VA. CoDE ANN. $\S 13.1-716$ to -722 (1985 \& Supp. 1987); 1987 Or. Laws ch. 52, \&§ 115-123, the RMBCA is presently under consideration by numerous state legislatures. For convenience, therefore, parallel citations will be made where appropriate to both the MBCA and the RMBCA. 
proposes a legislative rule designed to define and regulate that role more effectively.

Current corporate statutes assign directors a major role in merger transactions. ${ }^{4}$ Directors of both the acquiring company ${ }^{5}$ and the target ${ }^{6}$ must negotiate and approve the terms of a proposed merger. While target directors can unilaterally reject a merger proposal, they are generally required by statute to obtain shareholder approval in order to consummate a merger transaction. ${ }^{7}$ This statutory bifurcation of the roles

- See, e.g., CaL. Corp. Code $\S \S 1001,1101,1200$ (West 1977 \& Supp. 1987); Del. Code Ann. tit. 8, $\S \S 251$ (b), 271(a) (1983 \& Supp. 1986); N.Y. BuS. CoRP. LAw $\S \S 902,909$ (McKinney 1986); MBCA, supra note 3, §§ 71-72A, 79; RMBCA, supra note $3, \S \S 11.01-.02,12.02$.

"The "acquiring company" is the surviving corporation that after the merger will own either the stock or the assets of its merger partner.

- The "target" corporation is the acquired or disappearing corporation. After a merger, target shareholders will either own stock in the "acquiring company" or will receive cash or debt securities for their equity. Although size is the predominant factor in the choice of which merger partner becomes the acquiring company or the target company, other considerations may motivate the merger partners to structure the transaction so that the smaller company "acquires" the larger. See J. Freund, ANATOMY OF A MERGER 77-138 (1975) (analyzing a wide range of considerations that may affect the structuring of the merger transaction); G. MCCARTHY, ACQUISITIONS AND MERGERS 12-15 (1963) (discussing motivations for mergers).

7 See, e.g., Cal. Corp. Code $\$ \S 1001$ (a)(2), 1201 (West 1977 \& Supp. 1987); Del. Code AnN. tit. 8, $\S \S 251$ (c), 271(a) (1983 \& Supp. 1986); N.Y. Bus. CoRP. LAw \$§ 903(a), 909(a) (McKinney 1986); MBCA, supra note 3, \$§ 73, 79; RMBCA, supra note 3, $\S \S 11.03,12.02$. Generally, the shareholders of both merger partners are entitled to vote on the merger. However, unless the corporate charter otherwise provides, acquiring company shareholders may have no vote if no fundamental changes affect the acquiring company, and the premerger acquiring company shareholders retain a specified voting power. See, e.g., CAL. CoRP. CodE $§ 1201$ (b) (West 1977) (acquiring company shareholders have no vote if immediately after the merger they retain five-sixth shareholder voting power in acquiring company); DeL. Code ANN. tit. 8, § 251(f) (1983) (acquiring company shareholders have no vote unless acquiring company shares issued pursuant to the merger plan exceed $20 \%$ of outstanding common shares of acquiring company); MBCA, supra note 3, § 73(d) (same); RMBCA, supra note $3, \S 11.03(\mathrm{~g})(3)$ (same). Similarly, acquiring company shareholders may not have a vote if the acquisition is accomplished by means of a compulsory share exchange, see, e.g., MBCA, supra note $3, \S \S 72-\mathrm{A}, 73$ (acquiring company shareholder vote not required for share exchange); RMBCA, supra note $3, \S 11.03$ (same), or a triangle merger between a subsidiary of the acquiring company and the target. But see New YoRk StOck Exchange, New York Stock Exchange Listed Company ManUal $\S 312.00$ (1983 \& Supp. I 1984) (acquiring company shareholders must vote if acquisition increases outstanding shares by more than $18.5 \%$ ). Moreover, in certain parent-subsidiary mergers, the target shareholders have no vote. See, e.g., Del. Code ANN. tit. 8, § 253 (1983) (applicable to 90\% owned subsidiary); N.Y. Bus. CoRP. LAw $§ 905$ (McKinney 1986) (same); MBCA, supra note 3, § 75 (same); RMBCA, supra note $3, \S 11.04$ (same). Target shareholders may also lose voting rights in so-called "reverse triangle mergers" or upside-down acquisitions. See generally" Schulman \& Schenk, Shareholders Voting and Appraisal Rights in Corporate Acquisition Transactions, 38 Bus. LAw. 1529, 1529 (1983) (examining "the availability of shareholders' rights in a wide variety of transactions in which one corporation acquires another"). Sale of assets statutes typically require a vote of the seller's (target) 
of the target directors and the target shareholders presents two important concerns. First, some corporate directors involved in a transaction have an unavoidable conflict of interest. ${ }^{8} \mathrm{~A}$ completed merger necessitates the disappearance of the target corporation as an autonomous entity with the concomitant loss of control and job security for target managers. To counter these concerns, a bidder may offer target managers lucrative employment contracts or other incentives designed to secure their cooperation. Inside target directors ${ }^{9}$ may thus accept or reject a merger proposal for personal reasons without giving proper consideration to the best interests of their shareholders. Second, a merger represents a fundamental change in the nature of the target shareholders' investment. Corporate statutes recognize this fact by giving shareholders the right to vote on a merger proposal. ${ }^{10}$ Target directors, however, can agree to exclusive merger covenants with one bidder without their shareholders' prior knowledge or approval. These covenants can effectively disenfranchise the shareholders by predetermining the outcome of the shareholder vote. Moreover, some covenants deter, if not prevent, other bidders from making competing offers for the target corporation, thus depriving the shareholders of an objective measure of their directors' recommendations. ${ }^{11}$

Traditionally, the courts have addressed these concerns as issues involving the directors' fiduciary duties of care and loyalty. ${ }^{12}$ Objective monitors exist, however, that can police target directors' actions more effectively than has judicial review under fiduciary duty standards. The shareholder vote (the structural monitor), which is built into the structure of state corporate statutes, can police both the motives and the wisdom of a target board's resolution recommending a merger. In addition, the marketplace (the market monitor) can provide alternate choices for shareholders in the form of competing merger proposals or tender offers. This Article asserts that shareholders' interests in merger transactions would best be served by legal rules ensuring the unfettered

shareholders but not the purchaser's (acquiring company) shareholders, see CAL. Corp. CODE $\S 1001$ (West 1977 \& Supp. 1987); DEL. CODE ANN. tit. 8, § 271 (1983 \& Supp. 1986); N.Y. Bus. CoRP. LAw $\$ 909$ (McKinney 1986); MBCA, supra note 3, $\S 79$; RMBCA, supra note $3, \S 12.02$ (1984). For simplicity, this Article refers to all shareholders who are entitled to vote on a merger as "target shareholders."

B See infra notes 30-31 and accompanying text.

- Inside target directors are those directors who are also officers of the target. See H. Henn, Laws of Corporations and Other Business Enterprises § 204 (3d ed. 1983). In this Article, we use the term "target managers" interchangeably with "inside target directors," although some members of management may not be directors.

${ }^{10}$ See supra note 7 and accompanying text.

11 See infra notes 129-32 and accompanying text.

12 See infra notes 30-104 and accompanying text. 
operation of these structural and market monitors. ${ }^{13}$

This Article first examines the inside target directors' conflict of interest and demonstrates the difficulty in dealing with that problem through a traditional fiduciary duty analysis. Because little case law exists in the negotiated merger area, this discussion focuses primarily on tender offer cases that raise comparable issues of corporate control. ${ }^{14}$ We conclude that the courts have been ineffective monitors of the directors' loyalty obligations and that judicial decisions involving corporate control have had a negative impact on both the shareholders' role in merger transactions and the market for competing bids. The Article next addresses exclusive merger covenants, which are often approved by

1s As Professor Gilson so aptly stated the problem: "Management monitors the performance of components of the enterprise . . . But . . . the performance of management must also be monitored . . . Gilson, A Structural Approach to Corporations: The Case Against Defensive Tactics in Tender Offers, 33 STAN. L. REv. 819, 834-35 (1981) [hereinafter Gilson I] (suggesting that tender offers provide an appropriate monitor). Judicial review has been criticized as the most costly and least effective system to monitor or guide corporate managers. $C f$. Peckham, A Judicial Response to the Cost of Litigation: Case Management, Two-Stage Discovery Planning and Alternative Dispute Resolution, 37 RuTGers L. Rev. 253 (1985) (advocating aggressive case management by the judge to avoid the inefficiencies of full-scale litigation). Thus, an effective and efficient monitoring system should employ nonjudicial devices to the greatest extent possible. Traditional nonjudicial monitors of corporate decisionmaking, such as the product market, the capital market, and the market for corporate managers, do not operate when the directors make a one-time decision to "sell" the target. See Coffee, Regulating the Market for Corporate Control: A Critical Assessment of the Tender Offer's Role in Corporate Governance, 84 Colum. L. Rev. 1145, 1234-38 (1984) (summarizing these traditional monitors); Gilson I, supra, at 836-40. Therefore, in the "for-sale" setting of a merger transaction, the monitoring role of the shareholder vote and the market for corporate control assume greater importance. In addition, nonjudicial monitors are more effective if the monitor can retain the benefits of the monitoring. In such cases, the monitor's self-interest obviates the need for another layer of monitors. See Gilson I, supra, at 835 (citing Alchian \& Demsetz, Production, Information Costs, and Economic Organization, 62 AM. EcoN. REv. 777, 782 (1972)). Shareholders and competing bidders fit well into this model since each has a personal interest in the fate of the target corporation. Their interests should ensure willing and efficient monitoring of director activity without incurring the enormous costs associated with litigation. Moreover, the nature of corporate control transactions eliminates many transaction costs and "free rider" problems that would be associated with the monitoring of daily business transactions. See Anderson, Conflicts of Interest: Efficiency, Fairness and Corporate Structure, 25 UCLA L. REv. 738, 778-81 (1978) (analyzing problems inherent with shareholder supervision of daily business transactions); Davis, Judicial Review of Fiduciary Decisionmaking-Some Theoretical Perspectives, 80 Nw. U.L. REv. 1, 5-6 (1985) (analyzing problems associated with the monitoring of fiduciaries). See also infra note 23 (discussing the free rider problem).

14 Both mergers and tender offers generally involve a change of control of the target. Mergers usually cause the dissolution of the target, and tender offers are ordinarily premised upon the offeror's ability to obtain control of the target. Therefore, target managers have identical concerns when addressing either type of acquisition proposal. See infra note 34 . It should also be noted that tender offers and mergers cannot be viewed in isolation since they are often successive steps in the acquisition of a target. See infra note 224. 
target directors. We first suggest that statutory gaps create unnecessary uncertainty regarding the legal efficacy of covenants in merger agreements. The Article then analyzes judicial reactions to exclusive merger covenants and the negative effect of these covenants upon the structural and market monitoring systems.

Our conclusion is a legislative proposal designed to regulate the role of target directors in merger transactions. Under this proposal, only independent directors would be allowed to consider merger proposals because independence provides the most viable resolution of the directors' conflict of interest problem. In addition, our proposal seeks to clarify and limit the directors' power to enter into exclusive merger covenants without the prior approval of target shareholders in order to allow the effective functioning of the structural and market monitors.

\section{The Directors' Conflict of InTERest}

\section{A. Introduction}

It is a basic premise of modern corporate law that the ordinary business affairs of a corporation are governed by a board of directors. ${ }^{15}$ At common law, however, corporate directors had no formal role in a merger transaction. Such a fundamental corporate change could be accomplished only with the unanimous consent of the shareholders. ${ }^{16}$ Modern state corporation statutes have made two changes to the early rules. First, modern statutes have substituted a majority or supermajority shareholder approval requirement for the common law's unanimity provision. ${ }^{17}$ Second, modern statutes assign a substantial role to corporate directors by requiring them to pass a resolution recommending the proposed merger for shareholder approval. ${ }^{18}$ In order to

15 See, e.g., Cal. Corp. Code $\S 300$ (West 1977 \& Supp. 1987); Del. Code ANN. tit. 8, § 141(a) (1983); N.Y. Bus. CoRP. LAw $\S 701$ (McKinney 1986); MBCA, supra note $3, \S 35$; RMBCA, supra note $3, \S 8.01$ (b).

${ }^{16} 2 \mathrm{~V}$. Morawtz, A Treatise on the Law of Private Corporations $\S 951$ (2d ed. 1886); Carney, Fundamental Corporate Changes, Minority Shareholders, and Business Purposes, 1980 AM. B. Found. Res. J. 69, 77-82; Ward, The Legal Effect of Merger and Asset Sale Agreements Before Shareholder Approval, $18 \mathrm{~W}$. Res. L. Rev. 780, 788-90 (1967); Weiss, The Law of Take Out Mergers: A Historical Perspective, 56 N.Y.U. L. Rev. 624, 626-29 (1981).

${ }_{17}$ Most corporate statutes now state that unless otherwise provided in the corporate charter, a merger must be approved by a majority of the outstanding shares. See, e.g., Cal. Corp. Code $\$ \S 152,1201$ (West 1977 \& Supp. 1987); Del. Code ANN. tit. 8, § 251(c) (1983); MBCA, supra note 3, § 73; RMBCA, supra note 3, $\S 11.03(\mathrm{~b})(2)$. But see N.Y. Bus. CoRp. LAw § 903(a)(2) (McKinney 1986) (twothirds vote required to approve a merger).

18 See, e.g., CaL. CoRp. Code $\S 1200$ (West 1977 \& Supp. 1987) (statutory provisions outlining director activity in merger transactions); DEL. CoDE ANN. tit. 8, 
pass this resolution, corporate directors must necessarily identify a potential merger partner, negotiate the terms and conditions of the transaction, and approve a merger agreement. ${ }^{19}$ All of these steps generally occur before the shareholders are informed of the merger proposal. ${ }^{20}$

The statutory division of powers between shareholders and directors is not a prescription for equality. Directors under modern corporate statutes not only have a formal voice in the merger approval, but they also play the single and decisive role in one aspect of the merger

§.251(b) (1983) (same); N.Y. Bus. CoRP. LAw § 902(a) (McKinney 1986) (same); MBCA, supra note 3, §§ 71-72A (same); RMBCA, supra note 3, §§ 11.01(a)-.02(a) (same). From a historical perspective, it is unclear how the role of the directors in the merger process changed from that of bystanders to that of major participants. This evolution has paralleled the decreasing role of the shareholders. Both trends may have resulted from the increasing complexity and desirability of merger transactions.

18 The merger terms and collateral covenants that must be approved by the directors are embodied in what is termed an "agreement of merger" in some state statutes, see Cal. Corp. Code $\S 1101$ (West 1977 \& Supp. 1987); Del. Code AnN. tit. 8, $\S 251(b)-(c)$ (1983), a "plan of merger" in statutes patterned after the Model Business Corporation Act, see MBCA, supra note 3, § 71; RMBCA, supra note 3, §§ 11.01.03; N.Y. Bus. CORP. LAW $\S 902$ (McKinney 1986), and "articles of merger" in still other jurisdictions, see MD. CoRps. \& Ass'ns CoDE ANN. § 3-109 (1985). Sale of asset statutes are more vague than are merger statutes and typically require only that the target (selling) board and shareholders approve the transaction. See Gal. Corp. CODE § 1001 (West 1977 \& Supp. 1987); DEL. Code ANN. tit. 8, § 271(a) (1983 \& Supp. 1986); N.Y. Bus. CoRP. LAW § 909 (McKinney 1986); MBGA, supra note 3, § 79; RMBCA, supra note $3, \S 12.02(\mathrm{~b})$. The term "merger agreement," as used in this Article, is a generic term encompassing all such documents. We chose the term merger agreement because it seems to exhibit best the intent of the negotiating corporate directors who seek to reach an agreement on a specified merger proposal. Moreover, even in jurisdictions using statutes patterned after the Model Business Corporation Act in which a plan of merger is the statutory norm, the parties often utilize an acquisition agreement that embodies the "plan of merger." See, e.g., J. FREUND, supra note 6, at 147 n.11 (mechanics of merger "may be contained in an attached Agreement of Merger or similar document required under state law, which would be incorporated by reference into the acquisition agreement"); Acquisition Agreement Among Heinrich Bauer North America, New Winn's, and Winn's Stores, (Oct. 19, 1979), reproduced in R. McDermotr, Legal Aspects of Corporate FinanCE 733 (1985) (subject to Texas (MBCA) law); see also Buffalo Forge Co. v. Ogden Corp., 555 F. Supp. 892, 905 (W.D.N.Y.) (court, applying New York law, found a distinction between the overall merger agreement and the "plan of merger" that required shareholder approval), affd, 717 F.2d 757 (2d Cir.), cert. denied, 464 U.S. 1018 (1983).

${ }^{20}$ The courts are divided on the issue of when merger negotiations become material for disclosure purposes under the federal securities laws. Compare Levinson v. Basic, Inc., 786 F.2d 741 (6th Cir. 1986) (disclosure of merger negotiations required as agreement on price and structure not necessary for materiality), cert. granted, $107 \mathrm{~S}$. Ct. 1284 (1987) with Greenfield v. Heublein, Inc., 742 F.2d 751 (3d Cir. 1984) (merger negotiations need not be disclosed until parties agree on price and structure of transaction), cert. denied, 469 U.S. 1215 (1985). For analyses of the various requirements for corporations to disclose merger negotiations, see generally Brown, Corporate Communications and the Federal Securities Laws, 53 GEO. WASH. L. REV. 741, 78292 (1985); Note, Disclosure of Preliminary Merger Negotiations, 8 CARDozo L. REv. 197 (1986); Note, Rule 10b-5 and the Duty to Disclose Merger Negotiations in Corporate Statements, 96 YALE L.J. 547 (1987). 
process: the rejection of a merger offer. The directors' decision to reject a merger proposal is unilaterally determinative without shareholder input. ${ }^{21}$ Moreover, shareholders can only approve or reject merger proposals that the directors have already negotiated and approved; shareholders cannot independently initiate or amend merger agreements. ${ }^{22}$

Absent board involvement, target shareholders, as a large and disparate group, lack an adequate mechanism through which to negotiate and structure a favorable merger transaction. Individually, most shareholders lack the resources or economic incentives to evaluate independently a merger proposal. ${ }^{23}$ Given the increasing complexity of modern mergers, the significant role played by corporate directors in these transactions has become indispensable. ${ }^{24}$ The issue, therefore, is not whether the directors' role in a merger should be eliminated but whether the available systems that monitor the directors' performance

21 No one has seriously questioned the wisdom of the directors' statutory veto power of merger propositions, although this point is continually debated as it concerns the directors' role in tender offers. See, e.g., Lowenstein, Pruning Deadwood in Hostile Takeovers: A Proposal for Legislation, 83 Colum. L, REv. 249, 263-64 (1983) (suggesting that the tender offer phenomenon is a crack in the corporate statutory scheme of governance that otherwise prevents shareholders from unilaterally selling the firm).

${ }^{22}$ See, e.g., Cal. Corp. Code $\$ 1201$ (West 1977) (outlining the shareholders' role in merger transactions); DEL. CODE ANN. tit. 8, $\S 251$ (1983) (same); N.Y. Bus. CORP. LAW § 902 (McKinney 1986) (same); MBCA, supra note 3, § 73 (same); RMBCA, supra note $3, \S 11.03$ (same). These provisions should be compared with statutory provisions on asset sales, under which, in some jurisdictions, shareholders can initiate or amend proposals to sell substantially all of their corporation's assets. See, e.g., N.Y. BUS. CoRP. LAw $\S 909$ (McKinney 1986); MBCA, supra note 3, $§ 79$; RMBCA, supra note $3, \S 12.02$.

${ }^{23}$ This is a variation of the classic free rider problem. If a single shareholder conducts an independent evaluation of a merger proposal, the gain from such an evaluation will accrue to all the shareholders. Thus, the single shareholder will not receive a gain commensurate with the effort expended and will not ordinarily conduct the evaluation. It would require a collective action of the shareholders to justify the costs of such an evaluation. For a general discussion of the free rider problem, see M. Olson, The Logic of Collective ACTION (1971) (examining group behavior and the problems it presents); Clark, Vote Buying and Corporate Law, 29 CaSE W. Res. L. Rev. 776, 783-84, 785-90 (1979) (discussing and offering possible solutions to the free rider problem); Klein, The Modern Business Organization: Bargaining Under Constraints, 91 YALE L.J. 1521, 1544 (1982) (because single equity investors generally do not own a significant portion of the company or have all of their wealth in one company, they have little incentive to act); Levmore, Monitors and Free Riders in Commercial and Corporate Settings, 92 Y ALE L.J. 49, $59-75$ (1982) (discussing the free rider problem among shareholders and the way in which the corporation's financial structure responds). Moreover, even large institutional investors who may, indeed, independently evaluate merger proposals, will not often incur the cost of the proxy solicitation necessary to educate other shareholders. Clark, supra, at 784-85.

24 Even critics of directors' power recognize the necessity for extensive director involvement in the merger process. See, e.g., Buxbaum, The Internal Division of Powers in Corporate Governance, 73 CALIF. L. REv. 1671, 1699, 1701-02 (1985) (board has a legitimate and necessary role in merger negotiations). 
are operating efficiently. Such monitoring devices should police both the wisdom and loyalty of the directors' decisions in corporate control transactions.

In the remainder of this Part, we will first demonstrate that judicial review has proven an inadequate monitor of the wisdom and loyalty of the directors' decisions in the context of negotiated mergers. Thereafter, we will discuss the negative impact that these judicial decisions have had on the structural and market monitors.

\section{B. The Judicial Monitor}

The courts confine the permissible boundaries for their review of directors' decisions to an examination of whether the directors have fulfilled their fiduciary duties of care and loyalty. ${ }^{25}$ Such judicial restraint is embodied in the business judgment rule ${ }^{28}$ under which judicial review is confined to the directors' decisionmaking process, rather than their ultimate decision. ${ }^{27}$ As a result of this rule, the courts will neither overturn nor impose liability upon directors for their decisions unless the plaintiffs first overcome the rule's presumption ${ }^{28}$ that the directors

${ }^{25}$ See, e.g., Auerbach v. Bennett, 47 N.Y.2d 619, 630-31, 393 N.E.2d 994, 100001, 419 N.Y.S.2d 920, 926-27 (1979) (courts may inquire into disinterested independence of decisionmakers and the process by which they made their decision but may not evaluate the decision itself).

${ }^{28}$ One noted commentator has distinguished the business judgment rule from the business judgment doctrine, arguing that the former insulates directors from liability for their decisions, while the latter protects the decision itself from challenge. See Hinsey, Business Judgment and the American Law Institute's Corporate Governance Project: The Rule, the Doctrine, and the Reality, 52 Geo. WASH. L. Rev. 609, 611-13 (1984). This Article will use the term "business judgment rule" to refer to both concepts.

${ }^{27}$ See Aronson v. Lewis, 473 A.2d 805, 812 (Del. 1984) (under business judgment rule, court will not disturb judgment of directors absent abuse of their decisionmaking power). The business judgment rule developed as a response to several considerations. First, all state legislatures have vested corporate boards with management of the corporation, see supra note 15 and accompanying text, and shareholders elect directors to make these management decisions. Thus, directors who act carefully and in what they perceive to be the corporation's best interest should not be exposed to liability for decisions that turn out poorly or contrary to the shareholders' interests. In other words, directors are not expected to guarantee that their decisions will turn out well. Second, in entrusting directors to make decisions, shareholders must also give their directors the latitude to take risks and, correspondingly, to fail, without being exposed to liability. Finally, the doctrine reflects the courts' acknowledgement that they are ill-equipped to analyze and review business decisions. See, e.g., Block \& Prussin, The Business Judgment Rule and Shareholder Derivative Actions: Viva Zapata?, 37 Bus. LAw. 27, 3233 (1981) (recognizing that avoiding second-guessing choosing of directors' decisions and overburdening the courts are two major rationales underlying the rule); Siegel, Tender Offer Defensive Tactics: A Proposal for Reform, 36 Hastings L.J. 377, 380 \& nn.12.14 (1985) (listing traditional justifications for business judgment rule).

${ }^{28}$ It is well-established that under the business judgment rule, the plaintiff has the burden of proof in challenging a decision. See, e.g., Smith v. Van Gorkom, 488 


\section{fulfilled their duties of care and loyalty. ${ }^{29}$}

While few dispute the basic premises underlying the business judgment rule, the applicability of the doctrine to corporate control transactions is questionable because such transactions present inside target directors with an unavoidable conflict of interest. On one hand, the inside target directors may be motivated to reject an offer because of personal financial reasons, job security concerns, or a desire to maintain

A.2d 858, 872 (Del. 1985) (reasoning that it is presumed " "that in making a business decision, the directors of a corporation acted on an informed basis, in good faith and in the honest belief that the action taken was in the best interests of the company" " (quoting Aronson v. Lewis, 473 A.2d 805, 812 (Del. 1984)). For a discussion of the traditional allocation of the burden of proof and the Delaware Supreme Court's decision to shift the burden of proof in cases involving tender offer defensive tactics, see infra notes 37-50 and accompanying text.

29 Notwithstanding the theoretical contours of the business judgment rule, courts have occasionally deviated from the rule, suggesting that when these deviations occur the courts either have not understood or simply have rejected the theory underlying the rule. First, courts sometimes confuse the decisionmaking process, which is reviewable, with the decision, which is not reviewable. The basis for this confusion is that the process itself may be a series of "decisions." For example, a board of directors' decision not to hire outside experts to value the corporation prior to recommending a merger to the shareholders might be considered either as part of the reviewable process of the decision to sell the company or as a nonreviewable decision in itself. See Fischel, The Business Judgment Rule and the Trans Union Case, 40 Bus. LAw. 1437, 1446-47 (1985) (arguing that in Van Gorkom, the directors' decision not to consult outside experts, such as investment bankers, was a nonreviewable decision, rather than a reviewable part of the process). Second, there are times when, contrary to the theoretical model of the rule, courts actually seem to be reviewing the business decision itself. See Samjens Partners I v. Burlington Indus., Inc., 663 F. Supp. 614, 625 (S.D.N.Y. 1987) (although the court purported to apply the business judgment rule, it also secondguessed the directors' decision by making its own determination that the board's conclusions were justifiable); AC Acquisitions Corp. v. Anderson, 519 A.2d 103, 111 n.9 (Del. Ch. 1986) (noting "that some cases acknowledge a possibility-perhaps more theoretical than real-that a decision by disinterested directors following a deliberative process may still be the basis for liability if such decision cannot be 'attributed to any rational business purpose,'. . . or is 'egregious" " (quoting Sinclair Oil Corp. v. Levien, 280 A.2d 717, 720 (Del. 1971); Aronson v. Lewis, 473 A.2d 805, 815 (Del. 1984))). In other words, the issue is whether the business judgment rule precludes review of decisions by informed, disinterested directors or whether the decisions must meet some baseline test of rationality. See, e.g., Litwin v. Allen, 25 N.Y.S.2d 667, 699-700 (Sup. C. 1940) (without considering the process by which the decision was made, court decided bank directors' purchase of stock with seller's option to repurchase at sale price within six months was so improvident that directors should be held liable). Similarly, one may suspect that a court is disguising its conclusion that the decision was improper by finding some deficiency in the process. Third, the courts, in their review of the decisionmaking process, sometimes interchange the duty of loyalty with the duty of care. See MacAndrews \& Forbes Holdings, Inc. v. Revlon, Inc., 501 A.2d 1239, 1250 (Del. Ch. 1985) (finding that directors violated their duty of loyalty), affd, 506 A.2d 173,185 (Del. 1986) (finding that directors' same conduct violated their duty of care); see also Gilson I, supra note 13, at 827-29 (discussing how court blurred distinction between duty of care and duty of loyalty in Cheff v. Mathes, 41 Del. Ch. 494, 199 A.2d $548(1964)$ ). For a further discussion of the courts' intermingling of these two fiduciary duties, see infra notes 98-104 and accompanying text. 
the power and prestige deriving from their positions of control. ${ }^{30} \mathrm{Bid}-$ ders, on the other hand, recognizing these concerns and the importance of securing the cooperation of target management, may provide incentives to elicit target management's approval. ${ }^{31}$

The inevitability of the conflict of interest inherent in corporate control transactions makes it inappropriate to presume, as does the business judgment rule, that the inside directors have fulfilled their duty of loyalty.

\section{Merger Rejection Situations}

Despite the inside directors' inherent conflict of interest, there is scant case law involving the directors' fiduciary obligations in deciding to reject a merger. ${ }^{32}$ Judicial reaction to merger rejection cases can,

so Oesterle, The Negotiation Model of Tender Offer Defenses and the Delaware Supreme Court, 72 CoRNell L. Rev. 117, 130-31, 135 n.71 (1986). Oesterle observes that target managers may use tender offers to further their own interests at the expense of their shareholders' by allowing personal concerns to dominate decisions to resist or encourage a particular tender offer, id. at 130-35, and cites one study of 95 cash tender offers that found target management's resistance decreased correspondingly as the positive impact on target management's personal wealth grew. Id. at 135 \& n.71.

While financial motives, such as job security and salary concerns, present more obvious conflicts of interest, see Siegel, supra note 27, at 382 (discussing management's inherent conflict of interest in tender offer setting), some studies show that nonfinancial motives, such as power, prestige, and identification of ego with enterprise may actually be stronger in determining management's conduct. See J. BAKER, Executrve CoMPENSATION Practices of Retail Companies 1928-37, at 1-2 (Business Research Studies No. 23, 1939); M. Eisenberg, The Structure of the Corporation: A LEGal ANALySIS 30-34 (1976); Jensen \& Meckling, Theory of the Firm: Managerial Behavior, Agency Costs and Ownership Structure, 3 J. Fin. Econ. 305, 308-09 (1976) (arguing that unless otherwise constrained, target managers may seek to maximize their own welfare rather than that of the shareholders).

${ }^{31}$ Incentives could include compensation packages, employment contracts, stock options, or other side payments designed to secure management's cooperation. See, e.g., Samjens, 663 F. Supp. at 617 (plaintiff tender offeror alleged that target directors rejected tender offer and pursued merger agreement with a suitor who offered target management significant equity position in target if merger occurred); Singer v. Magnavox Co., 380 A.2d 969, 971 (Del. 1977) (after rejecting initial tender offer, target management agreed to a modified offer that included employment contracts between several target directors and the bidder); Pupecki v. James Madison Corp., 376 Mass. 212, 216, 382 N.E.2d 1030, 1033 (1978) (minority shareholder alleged that consideration paid for corporation's assets was substantially less than fair market value and that this underpayment was made up by payments directly to the majority shareholder under the guise of separate employment and noncompetition agreements); Barr v. Wackman, 36 N.Y.2d 371, 375-76, 329 N.E.2d 180, 184, 368 N.Y.S.2d 497, 503 (1975) (target directors allegedly accepted a lower stock price offer in return for an offer that included employment contracts for some target officers with the acquirer). For a further discussion of Barr v. Wackman, see infra note 107.

${ }_{32}$ See, e.g., Singer, 380 A.2d at 971-71 (target directors withdrew initial opposition to a tender offer, which was to be the first step in a freeze-out merger, after they reached an agreement that included, among other changes, employment contracts with 
however, be anticipated from the courts' responses to the plethora of cases involving hostile tender offers. ${ }^{33}$ Those cases raise analogous conflict of interest issues because directors' implementation of tender offer defensive tactics in order to keep the target independent is comparable to their decision to reject a merger. ${ }^{34}$

Some courts have acknowledged that target directors have an inherent conflict of interest when faced with a hostile tender offer ${ }^{35} \mathrm{~A}$ logical extension of this reasoning would suggest displacing the presumption of the business judgment rule with the fairness test, which is

the offeror), analysis partially overruled in Weinberger v. UOP, Inc., 457 A.2d 701, 704, 715 (Del. 1983); Barr, 36 N.Y.2d at 375-76, 329 N.E.2d at 184, 368 N.Y.S.2d at 502 (alleging that target directors rejected merger offer but approved less attractive tender offer accompanied by incentives for target management). Note, however, that neither case squarely presents the issue of target management's conflict of interest in a merger: Singer's main focus is on management's obligations when it takes its corporation private, and Barr's focus is on the procedural requirements for the plaintiff's derivative action. The paucity of cases may be due to the fact that in a merger rejection situation, the shareholders are usually unaware that any merger offer has been proposed. See supra note 20 and accompanying text.

ss See, e.g., Hanson Trust PLC v. ML SCM Acquisition, Inc., 781 F.2d 264, 267 (2d Cir. 1986) (shareholder alleging that directors' approval of a lock-up option to prevent a tender offer constituted a breach of their fiduciary duties); Moran v. Household Int'l, Inc., 500 A.2d 1346, 1351 (Del. 1985) (challenging directors' adoption of a preferred share purchase rights plan as an anticipatory tender offer defensive tactic); Unocal Corp. v. Mesa Petroleum Co., 493 A.2d 946, 955 (Del. 1985) (shareholder alleging that discriminatory exchange offer violated fiduciary duties owed by directors). One reason that an abundance of hostile tender offer cases exists is that unlike the shareholders' ignorance of merger proposals, supra notes 20,32, shareholders do learn of tender offers because the federal securities laws require a bidder to notify target shareholders of the tender offer. The Williams Act, 15 U.S.C. $\$ \S 78 \mathrm{~m}(\mathrm{~d})-(\mathrm{e}), 78 \mathrm{n}(\mathrm{d})-$ (f) (1982 \& Supp. III 1985) (requiring an offeror to file information with the Securities and Exchange Commission and the target at the same time such information is first published, sent, or given to any target shareholders).

34 Both mergers and tender offers involve decisions by target directors to avoid a transfer of control. In a merger, statutes give the directors this ability, see supra note 18 and accompanying text, and tender offer defensive tactics give target directors a blocking power equivalent to their statutory power in a merger. In attempting to avoid a transfer of control, inside target directors in either transaction are vulnerable to conflicts of interest, which, in turn, raise concerns that these directors cannot fulfill their fiduciary duty of loyalty. It is, therefore, likely that courts will review the responsibilities of directors in merger rejection cases in a manner similar to their review of tender offer cases in which the directors employ tactics designed to retain the target's independence. See also supra note 14 (discussing analogy between merger and tender offer transactions).

3s See, e.g., Treadway Cos. v. Care Corp., 638 F.2d 357, 383 (2d Cir. 1980) (recognizing that inherent risks of self-dealing are present in any transaction affecting control); Crane Co. v. Harsco Corp., 511 F. Supp. 294, 305 (D. Del. 1981) (citing Bennett v. Propp, 41 Del. Ch. 14, 22, 187 A.2d 405, 409 (1962)) (directors have inherent conflict of interest when stock purchase occurs in context of tender offer); Northwest Indus., Inc. v. B.F. Goodrich Co., 301 F. Supp. 706, 712 (N.D. Ill. 1969) (acknowledging that whenever target management resists tender offer, officers and directors may be accused of preserving their jobs at the expense of the corporation). 
the test most often used to monitor transactions in which a party has a conflict of interest. $^{36}$ Ironically, most courts traditionally have decided that because this conflict of interest is inherent, the plaintiffs must prove something more than the directors' desire to remain in control before the courts will displace the presumption of the business judgment rule. The courts have required the plaintiffs not only to bear the initial burden of proof, ${ }^{37}$ but also to satisfy additional criteria, such as proving that the defensive tactic could not be attributed to any rational business purpose, ${ }^{38}$ or that the directors were motivated by bad

${ }^{36}$ See Treadway Cos., 638 F.2d at 382 (holding that once conflict of interest is demonstrated, directors have burden of proving transaction was fair); Sinclair Oil Corp. v. Levien, 280 A.2d 717, 720 (Del. 1971) (holding that if conflict of interest exists, parent corporation must prove fairness of transaction with its subsidiary); see also DEL. CODE ANN. tit. 8, \& 144(a)(3) (1983) (providing that a conflict of interest transaction is not void or voidable solely for that reason if the transaction is fair as to the corporation as of the time it is authorized, approved, or ratified by the board of directors or the shareholders); $c f$. Fliegler v. Lawrence, 361 A.2d 218, 221 (Del. 1976) (fact that all shareholders, rather than just the disinterested shareholders, voted did not relieve the corporation of the burden of proving fairness). One court has concluded that the personal benefit derived from the directors' maintaining their control position was sufficient to require them to prove the fairness of the defensive tactics they used to combat the tender offer. Heckman v. Ahmanson, 168 Cal. App. 3d 119, 128, 214 Cal. Rptr. 177,183 (1985).

The courts' adherence to the business judgment rule may result partly from their reluctance to apply a fairness test, which necessarily requires an evaluation of the business decision. As Professor Gilson has argued:

Where the management action taken-repurchase of the outsider's stock-has as its announced purpose preventing a shift in control of the corporation, the conflict of interest is apparent. Reviewing management's action under the fairness standard, however, presents substantial difficulties. Inquiry could be made concerning whether the price paid by the company was fair. . . [M]anagement's conflict of interest was not in the price paid, but in the decision to acquire the shares at all. Applying a fairness standard to this decision, however, requires a court to determine whether it was "fair" for control to remain with management rather than shift to the offeror. And this inquiry must necessarily focus on whether the shareholders would be better off with existing management or by selling their shares. But this is an investment decision, made continually by shareholders in deciding whether to sell their shares, and raises the same issue of judicial competence which justifies a restrictive judicial role . . .

Gilson I, supra note 13 , at 827.

${ }_{37}$ See, e.g., Hanson Trust PLC, 781 F.2d at 273 (finding that plaintiff bears the initial burden of proving directors' breach of fiduciary duty in connection with tender offer defensive tactic); Panter v. Marshall Field \& Co., 646 F.2d 271, 296 (7th Gir.) (requiring plaintiffs to bear burden of proof, even though plaintiffs alleged directors' desire to retain control motivated their tender offer defensive tactic), cert. denied, 454 U.S. 1092 (1981); Treadway Cos., 638 F.2d at 382 (finding that directors' approval of stock sale to avert a takeover was not sufficient evidence of a conflict of interest for plaintiffs to be relieved of burden of proof); Johnson v. Trueblood, 629 F.2d 287, 292 (3d Cir. 1980) (proof that a desire for control was directors' motivation in takeover context not enough to shift burden to defendants), cert. denied, 450 U.S. 999 (1981). ${ }_{38}$ See, e.g., Whittaker Corp. v. Edgar, 535 F. Supp. 933, 950-51 (N.D. Ill. 1982) 
faith, ${ }^{38}$ self-dealing, fraud, or overreaching. ${ }^{40}$ Because plaintiffs almost always lose under these judicial standards, ${ }^{41}$ some scholars ${ }^{42}$ and even a few judges ${ }^{43}$ have criticized these standards as ineffective monitors of directors' compliance with their duty of loyalty.

While some courts remain steadfast in their adherence to the business judgment rule, ${ }^{44}$ the Delaware Supreme Court has acknowledged

(requiring plaintiff to show the defensive tactic had no rational business purpose).

${ }^{39}$ See, e.g., Panter, 646 F.2d at 297 (holding that plaintiff must establish bad faith, overreaching, self-dealing, or any other fraud); Treadway Cos., 638 F.2d at 382 (requiring showing of bad faith, self-dealing, or fraud); Johnson, 629 F.2d at 293 (requiring plaintiff to show, at a minimum, some sort of bad faith on the part of the defendant); Gearhart Indus., Inc. v. Smith Int'l, Inc., 592 F. Supp. 203, 225 (N.D. Tex.) (directors' business judgment not reviewable unless made in bad faith), modified, 741 F.2d 707 (5th Cir. 1984); Whittaker, 535 F. Supp. at 950-51 (plaintiff must show bad faith or abuse of discretion on the part of directors).

to See Panter, 646 F.2d at 297 . Even if a plaintiff rebuts the good-faith presumption, the plaintiff has merely shifted the burden of proof to the defendant directors. See, e.g., Treadway Cos., 638 F.2d at 382 (once plaintiff demonstrates bad faith, burden shifts to directors). The directors then must show that the primary reason for their decision was to further a proper corporate purpose. See $i d$. Defendants can easily meet this burden because a number of business reasons can be adduced to explain why a target board may consider a takeover undesirable and therefore decide to resist. See Siegel, supra note 27, at 386. An inadequate offering price or inappropriate timing are all common justifications given by directors to explain their resistance to a takeover. See Lipton, Takeover Bids'in the Targets'Boardroom: An Update After One Year, 36 Bus. LAw. 1017, 1026-28 (1981) (outlining procedures and reasons for rejecting offer to be followed by board confronted with hostile tender offer); see also infra notes 53-56 and accompanying text (discussing directors' justifications for resisting tender offers).

11 Courts have protected the following potent defensive tactics under the business judgment rule: a selective stock repurchase that excluded the minority shareholder/ tender offeror, see Unocal Corp. v. Mesa Petroleum Co., 493 A.2d 946, 955 (Del. 1985), a preferred share purchase rights plan that would substantially dilute any potential acquirer's holdings, see Moran v. Household Int'l, Inc., 500 A.2d 1346, 1353 (Del. 1985), a counter-tender offer for the original offeror's stock, see Martin Marietta Corp. v. Bendix Corp., 549 F. Supp. 623, 633-34 (D. Md. 1982), and an acquisition for the purpose of creating antitrust problems for a potential acquirer, see Panter, 646 F.2d at 297.

${ }_{12}$ See Easterbrook \& Fischel, The Proper Role of a Target's Management in Responding to a Tender Offer, 94 HARV. L. REv. 1161, 1194-1204 (1981) [hereinafter Easterbrook \& Fischel I] (rejecting business judgment rule for reviewing directors' inherent conflict of interest); Gilson I, supra note 13, at 826 (discussing how business judgment rule does not protect adequately shareholders in change of control situations).

${ }_{43}$ See, e.g., Minstar Acquiring Corp. v. AMF, Inc., 621 F. Supp. 1252, 1260 n.6 (S.D.N.Y. 1985) ("The right of a shareholder to sell his stock is a private transaction between a willing seller and a willing purchaser and in no way implicates the business judgment rule. Therefore, a board of directors' assertion of a unilateral right, under the business judgment rule, to act as a surrogate for the shareholder's independent right of alienation of his stock is troublesome."); see also Panter, 646 F.2d at 299 (Cudahy, J., concurring in part and dissenting in part) (emphatically disagreeing that business judgment rule with its presumption of sound business judgment should protect directors fending off takeover threat); cf. Johnson, 629 F.2d at 301 (Rosenn, J., concurring in part and dissenting in part) (once plaintiff has shown directors' desire to maintain control, directors should bear burden of justifying transaction).

14 See, e.g., Hanson Trust PLC v. ML SCM Acquisition, Inc., 781 F.2d 264, 
the criticism that the rule provides only weak monitoring of the directors' loyalty. In Unocal Corp. v. Mesa Petroleum Co., ${ }^{45}$ the court stated that with "the omnipresent specter that a board may be acting primarily in its own interests, rather than those of the corporation and its shareholders, there is an enhanced duty which calls for judicial examination at the threshold before the protections of the business judgment rule may be conferred." ${ }^{46}$ This new test transfers the initial burden of proof from the plaintiff to the target board. ${ }^{47}$ At the outset, the board must show the reasonableness of its actions, which requires demonstrating that: (1) the board acted with "good faith and reasonable investigation" because it had reasonable grounds to believe that the takeover presented a danger to corporate policy and effectiveness; ${ }^{48}$ and (2) the defensive tactic the board chose was "reasonable in relation to the threat posed."49 If the board successfully makes these two showings, the ultimate burden of proof shifts to plaintiffs to show "by a preponderance of the evidence that the directors' decisions were primarily based on perpetuating themselves in office, or some other breach of fiduciary duty such as fraud, overreaching, lack of good faith, or being uninformed .....",

274-77 (2d Gir. 1986); see also Treco, Inc. v. Land of Lincoln Sav. \& Loan, 749 F.2d 374, 378-79 (7th Cir. 1984) ("[T]he courts generally have determined that the business judgment rule continues to apply to insulate directors' actions in challenge to control contexts, despite the directors' apparent self-interest, unless self-interest was the 'sole or primary purpose' for the directors' resistance." (citations omitted)); Turner Broadcasting Sys., Inc. v. GBS, Inc., 627 F. Supp. 901, 908 (N.D. Ga. 1985) ("In considering tender offers management has the responsibility to oppose offers which in its best judgment are detrimental to the company or its stockholders."); Horwitz v. Southwest Forest Indus., Inc., 604 F. Supp. 1130, 1134 (D. Nev. 1985) (because a corporate board's "managerial function includes making the decision to welcome or oppose a proposed merger or takeover[,]" court applied business judgment rule to directors' tender offer defensive tactics).

45 493 A.2d 946 (Del. 1985). In Unocal, the court held that Mesa Petroleum's two-tiered, front-loaded cash tender offer was "inadequate and coercive." Id. at 958. Therefore, the court found that Unocal's directors acted reasonably in conducting a selective stock repurchase program that excluded Mesa.

46 Id. at 954.

47 Id. at 955 (stating that, in the face of the conflict of interest inherent in a threat to their control, "directors must show that they had reasonable grounds for believing that a danger to corporate policy and effectiveness existed because of another person's stock ownership" (citation omitted)).

48 Id. (citing Cheff v. Mathes, 41 Del. Ch. 494, 506, 199 A.2d 548, 555 (1964)).

38 Id. The court in AG Acquisitions Corp. v. Anderson, Clayton \& Co., 519 A.2d 103 (Del. Ch. 1986), maintained that the Unocal standard developed as a "more flexible, intermediate form of judicial review" between evaluation of the fairness or merits of the target board's decisions or total deference to the target board's decision, as the business judgment rule requires. $I d$. at 111 .

${ }^{80}$ Unocal, 493 A.2d at 958; see also Moran v. Household Int'l, Inc., 500 A.2d 1346, 1356 (Del. 1985) (following Unocal standard); Ivanhoe Partners v. Newmont Mining Corp., Nos. 9281, 9221 (Del. Ch. Oct. 15, 1987) (applying Unocal test); $A C$ 
At first blush, Unocal represents a major victory for target shareholders. The court's decision to shift the initial burden of proof from the plaintiffs to the defendants appears to signify a major change in judicial policy. ${ }^{\mathbf{5 1}}$ Under Unocal's test, target directors must first demonstrate their "good faith and reasonable investigation" by showing that they had reasonable grounds for perceiving a danger to corporate policy and effectiveness. Broken down, this test requires the showing of three components: a danger to corporate policy and effectiveness; good faith; and reasonable investigation. The first two components involve the directors' loyalty, while the third component presents a classic duty of care issue.

Upon closer examination, however, the "new" requirements the court imposed on the directors seem fairly inconsequential and far less stringent than a fairness test. ${ }^{52}$ While professing concern over the directors' conflict of interest, the court in Unocal constructed a toothless standard for testing whether directors have fulfilled their duty of loyalty. Requiring proof of a danger to corporate policy and effectiveness is an insignificant requirement because directors can almost always cite a conflict in policy between the corporation and the bidder. ${ }^{53}$ The shallowness of this Unocal requirement is highlighted by Moran $v$. Household International, Inc., ${ }^{54}$ in which the Delaware Supreme Court sanctioned the corporation's enactment of potent defensive tactics in advance of any specific danger to the corporation's policies. ${ }^{\mathbf{5 5}}$ Indeed, one Delaware court held that this first Unocal component was satisfied,

Acquisitions Corp., 519 A.2d at 112 (same); MacAndrews \& Forbes Holdings, Inc. v. Revlon, Inc., 501 A.2d 1239, 1247 (Del. Ch. 1985) (citing Unocal's two-step analysis), aff'd on other grounds, 506 A.2d 173 (Del. 1986).

${ }_{51}$ While the court claimed to be maintaining simply its longstanding policy of requiring those with a conflict of interest to bear the burden of proof, Unocal, $493 \mathrm{~A}$. $2 \mathrm{~d}$ at 955 , Unocal is a departure from previous Delaware cases in classifying challenges to corporate control as conflict of interest transactions. See id.

${ }_{52}$ See supra note 36 (discussing difficult analytic components of the fairness test).

63 See Gilson I, supra note 13 , at 828 \& n.31 ("inventive counsel [can] always discover" a conflict and management can "develop[] appropriate documents"); Siegel, supra note 27, at 386-87 (discussing the ease with which directors find offer to be in conflict with target corporation's policy).

o4 500 A.2d 1346 (Del. 1985).

ss $I d$. at 1356-57 (concluding that adoption of a rights plan was within the authority of the directors and was necessary to protect the corporation from anticipated coercive acquisition techniques); see also Polk v. Good, 507 A.2d 531, 537 (Del. 1986) (upholding the repurchase of a corporation's shares to eliminate perceived threat, so long as it was done in good faith and with reasonable investigation); Note, Delaware Serves Shareholders the "Poison Pill": Moran v. Household International, Inc., 27 B.C.L. REv. 641, 669 (1986) (arguing that the Moran court undermined Unocal by applying the business judgment rule despite the fact that no specific threat existed); infra notes 70-71 and accompanying text (discussing cases upholding anticipatory defensive actions). 
even though the tender offer contained no threat of injury to the target corporation or its shareholders, simply because the court believed that the defensive tactic served a general corporate purpose, rather than one that was personal to the directors. ${ }^{56}$ Given these recent interpretations, the requirement that there be a danger to corporate policy is inconsequential.

Unocal also requires directors to have a good faith basis for believing that this danger to corporate policy exists. ${ }^{57}$ The good faith component simply requires the directors to demonstrate why they believe that the proposed takeover will affect the corporation negatively. ${ }^{58}$ This too

sB AC Acquisitions Corp. v. Anderson, Clayton \& Co., 519 A.2d 103 (Del. Ch. 1986). The court stated:

There is no evidence that the . . offer-which is non-coercive and at a concededly fair price-threatens injury to shareholders or to the enterprise. However, I take this aspect of the test to be simply a particularization of the more general requirement that a corporate purpose, not one personal to the directors, must be served by the [defensive tactic]. As so understood, it seems clear that [the defensive tactic] in these circumstances meets this element of the appropriate test.

Id. at 112. The Delaware Chancery Court also found that the defensive tactic, which was an issuer tender offer, served a valid corporate purpose by providing shareholders with an alternative to the concededly fair third party tender offer. Id.; see also infra note 118 (discussing how state antitakeover statutes may allow directors to satisfy the first component of the Unocal test easily).

B7 493 A.2d at 955 . "In practice, directors demonstrate their good faith by documenting one or more plausible business purposes or constituency-related reasons, (e.g., shareholders, employees or local communities) to justify the rejection of the takeover bid and the use of defensive tactics." Balotti, Abrams \& Sparks, Directors' Fiduciary Duties in Corporate Control Contests, 18-2 INST. ON SEc. REG. 9, 51 (1986) [hereinafter Fiduciary Duties].

${ }^{58}$ The business judgment rule presumes that a director acts in good faith when making business decisions. Smith v. Van Gorkom, 488 A.2d 858, 873 (Del. 1985). Good faith consists of two elements. First, a director must take action with the honest belief that such action is in the best interests of the corporation. Second, a director must make decisions for a rational business purpose.

The "honest belief in the best interest of the corporation" element examines the director's actions to determine whether she is motivated by the shareholders' best interests or by her own interests. Oddly enough, however, a motive to retain control is not generally sufficient to show that a director failed to act in good faith. See Panter v. Marshall Field \& Co., 646 F.2d 271, 297 (7th Cir.) (finding that, even if directors' motive in entering into the transactions was to fend off an acquisition, the plaintiffs failed to establish that this was the primary purpose and thus bad faith was not shown), cert. denied, 454 U.S. 1092 (1981); Treadway Cos. v. Care Corp., 638 F.2d 357,383 (2d Cir. 1980) (finding that plaintiffs failed to meet burden of showing improper motive or bad faith); Johnson v. Trueblood, 629 F.2d 287, 292 (3d Cir. 1980) (finding that, because directors have certain amount of self-interest in everything they do, merely showing a motive to retain control does not, in and of itself, constitute bad faith), cert. denied, 450 U.S. 999 (1981). Courts have held, however, that directors have not acted in good faith if they acted solely or primarily in order to perpetuate their control over the corporation or for some illegitimate objective. See, e.g., Frantz Mfg. Co. v. EAC Indus., 501 A.2d 401, 408 (Del. 1985) ("broad authority [of the business judgment rule] allows a Delaware corporation to deal selectively with its stockholders, 
is a modest undertaking, given the vagueness of the requirement. ${ }^{50}$ Thus, directors can dispense summarily with both loyalty components of the first prong of the Unocal test by invoking a well-tested litany of reasons justifying independence. Substance is scarcely reached.

The final component of the first prong of the Unocal test requires the directors to establish reasonable grounds for believing the offeror's policies present a danger to the target. This is an admonition to the directors to fulfill their duty of care. In a recent decision, the Delaware Supreme Court stated that the duty of care requires directors to inform themselves "of all material information reasonably available to them." The directors can meet this component by recording the time, attention, and information they gathered and reviewed before making a decision. ${ }^{61}$

Unocal's second requirement is that the defensive tactic be "rea-

so long as the directors have not acted out of the sole or primary purpose to entrench themselves in office").

Generally, courts also apply a rational business purpose test in assessing good faith. Directors demonstrate their good faith by documenting plausible purposes or constituency-related reasons to justify employing defensive tactics. See Fiduciary Duties, supra note 57 , at 51 .

In the derivative action context, courts address the directors' good faith in assessing their disinterestedness and independence. In this context, one court characterized the good faith requirement as an "inquiry . . . into the spirit and sincerity with which the investigation was conducted, rather than the reasonableness of its procedures or bases for conclusions." Abella v. Universal Leaf Tobacco Co., 546 F. Supp. 795, 800 (E.D. Va. 1982).

so In Unocal, for example, the court did not analyze whether the directors had acted in good faith. The court simply stated that the Court of Chancery had found that these directors had implemented a defensive tactic in the good faith belief that the tender offer was inadequate. Unocal, 493 A.2d at 958; see also supra note 58 (discussing judicial interpretations of good faith).

${ }_{60}$ Van Gorkom, 488 A.2d at 872; see also Samjens Partners I v. Burlington Indus., Inc., 663 F. Supp. 614, 625 (S.D.N.Y. 1987) (concluding that the board reached all of its decisions after thorough consultation with its financial and legal advisors). The Samjens court determined that the board's

decisions were based on reasonable and thorough investigations, and its conclusions were justifiable and in good faith. . . . The Board fulfilled its duty of care in the takeover context, and its decision is entitled to the protection of the business judgment rule. In short, if the procedure the Board followed and the merger agreement it approved were not protected by the business judgment rule, the Court doubts that any merger agreement would be allowed in the context of takeover contests.

Id.

81 One noted scholar observed that, when the issue before the board involves the company's shares, "the directors would be well advised to be more than usually alert, deliberative, focused, prepared, counseled, paper-tracked, and generally professional in their behavior." Manning, Reflections and Practical Tips on Life in the Boardroom After Van Gorkom, 41 Bus. Law. 1, 6 (1985); see also Lowenstein, supra note 21, at 314 ("[T]here are no smoking guns anymore. The same drastic actions occur, but only after carefully orchestrated board meetings."). 
sonable in relation to the threat posed,"62 that is, that the directors respond proportionately to the threat. Analyzing the seriousness of the threat and the appropriateness of the directors' response to that threat, however, requires the courts to substitute their business judgment for that of the directors. Courts are both ill-equipped and unwilling to undertake any real review of substantive decisions. ${ }^{63}$ As a result, courts have given directors tremendous latitude in assessing the reasonableness of the directors' response and have invalidated only those responses that are blatantly unreasonable. For example, in Unocal, the Delaware Supreme Court upheld an exclusionary self-tender. ${ }^{84}$ Since that time, the court has held that a target's enactment of a poison pill ${ }^{\mathrm{es}}$ and greenmail

${ }^{62}$ Unocal, 493 A.2d at 955 . Specifically, the court said:

A further aspect is the element of balance. If a defensive measure is to come within the ambit of the business judgment rule, it must be reasonable in relation to the threat posed. This entails an analysis by the directors of the nature of the takeover bid and its effect on the corporate enterprise. Examples of such concerns may include: inadequacy of the price offered, nature and timing of the offer, questions of illegality, the impact on "constituencies" other than shareholders (i.e., creditors, customers, employees, and perhaps even the community generally), the risk of nonconsummation, and the quality of securities being offered in the exchange.

Id; see also Lipton, Mirvis \& Brownstein, Takeover Defenses and Directors' Liabilities, in 1 Takeover Defenses and Directors' Liabilities 3, 29-34 (M. Lipton ed. 1986) (discussing courts' application of "reasonable in relation to the threat posed" standard).

${ }^{63}$ See supra note 27 (discussing reasons for judicial adoption of business judgment rule). But see Oesterle, supra note 30 , at 118 n.7 (questioning whether the Unocal requirement is any different from the fairness test); Veasey, The New Incarnation of the Business Judgment Rule in Takeover Defenses, 11 DEL. J. CoRP. L. 503, 512 (1986) (predicting that courts applying Delaware law will scrutinize more strictly both procedure and substance of board decisions to implement tender offer defensive tactics).

${ }_{64} 493 \mathrm{~A} .2 \mathrm{~d}$ at 957 . In Unocal, the Delaware Supreme Court found that the board reasonably believed that Mesa's tender offer was "inadequate and coercive." Id. at 958. Thus, the court upheld the board's exclusionary self-tender for providing shareholders with an alternative that would protect the corporation from the threat posed by Mesa's offer. Id.

os Moran, 500 A.2d at 1353. A "poison pill" is a share purchase rights plan designed to dilute an unwanted acquirer's holdings in the target company. The most common poison pills are plans involving "flip-over" rights and note purchase rights. The flip-over plan is invoked when an acquirer purchases stock in excess of a specified amount and then proceeds unilaterally to acquire the remaining common stock. After such an acquisition occurs, the holders of the target corporation's flip-over rights can purchase the acquirer's stock at a discount price. In contrast, a note purchase rights plan gives the holder the right to "put" his stock to the issuer in exchange for a specified package of securities if a specified percentage of the company is acquired by a third party. For a full discussion of poison pills, see Lipton, Mirvis \& Brownstein, supra note 62 , at $95-127$.

In Moran, the court addressed the legitimacy of adopting a poison pill, not the board's duties in triggering the pill. 500 A.2d at 1350-55. The court found that the poison pill was reasonable in light of management's concern with the proposed two-tier "boot-strap" "bust-up" tender offer. Id. at 1357; see also Gearhart Indus., Inc. v. 
repurchase $^{68}$ were reasonable in relation to the threat posed. In fact, almost all of the tactics enjoined as unreasonable since Unocal have been those that stifled competitive bidding when the directors decided to sell the company. ${ }^{67}$ Directors' decisions to employ potent defensive tactics to keep the company independent, when undertaken with a record that evidences due care, however, have almost uniformly been upheld. ${ }^{68}$

Smith Int'l, Inc., 741 F.2d 707, 724 (5th Cir.) (upholding use of springing warrants), modifying, 592 F. Supp. 203 (N.D. Tex. 1984); Revlon, Inc. v. MacAndrews \& Forbes Holdings, 506 A.2d 173, 180 (Del. 1986) (finding that adoption of rights plan was not unreasonable in relation to threat posed).

${ }^{66}$ See Polk v. Good, 507 A.2d 531, 537 (Del. 1986) (finding that greenmail repurchase at $3 \%$ premium was reasonable response because directors had justifiable belief that investors posed an immediate disruption and potential long-term threat). "Greenmail" is the term used to describe the situation where a stockholder has a substantial number of shares and urges the corporation to buy his shares at a premium. Corporations will buy these shares to thwart a potential takeover attempt by the greenmailer. See Lipton, Mirvis \& Brownstein, supra note 62, at 15-18; see also Cheff v. Mathes, 41 Del. Ch. 494, 508, 199 A.2d 548, 556 (1964) (upholding greenmail repurchase plan because court found that there was a reasonable threat to the continued existence of the corporation). But see Heckman v. Ahmanson, 168 Cal. App. 3d 119, 127-28, 214 Cal. Rptr. 177, 183 (1985) (ruling against a greenmail repurchase plan that the court found was motivated by directors' desire to perpetuate their own control instead of serving the corporate interest).

${ }^{67}$ See Hanson Trust PLC v. ML SCM Acquisition, Inc., 781 F.2d 264, 282 (2d Cir. 1986) (injunction ordered to block lock-up agreement that "the directors knew or should have known . . . would foreclose any better offers"); Revlon, 506 A.2d at 181, 184 (initial adoption of rights plan was found reasonable "considering the threat posed"; a subsequent lock-up agreement once the board decided to sell the corporation was held not reasonable and constituted a breach of their duty of care); see also infra notes 87-93 and accompanying text (discussing tactics adopted after directors decide to sell corporation). But see Ivanhoe Partners v. Newmont Mining Corp., Nos. 9281, 9221 (Del. Ch. Oct. 15, 1987) (holding plaintiff showed probability of success on the merits for a preliminary injunction against implementation of a standstill agreement that "guaranteed the incumbency of the Newmont Board (or their designees) and, as a practical matter, assured the defeat of any hostile takeover attempt for possibly ten years . . . [because] those offending provisions made the . . . standstill agreement unreasonable in relation to the threat posed").

${ }^{68}$ But see supra note 67 (discussing court's holding in Ivanhoe Partners v. Newmont Mining Corp., Nos. 9281, 9221 (Del. Ch. Oct. 15, 1987), that standstill agreement was unreasonable in relation to the threat posed).

Two of the cases since Unocal that held target directors' responses to hostile tender offers unreasonable are difficult to categorize. First, in Dynamics Corp. of Am. v. CTS Corp., 794 F.2d 250 (7th Cir. 1986), rev'd on other grounds, 107 S. Ct. 1637 (1987), the Court of Appeals for the Seventh Circuit applied Indiana law, which the court said "takes its cues" from Delaware. Id. at 253. The Seventh Gircuit affirmed the decision of the District Court for the Northern District of Illinois to grant a preliminary injunction against CTS's rights plan. Id. at 259. The court justified its ruling by indicating that the target directors had not acted reasonably in adopting the plan after a tender offer and proxy fight had begun. Id. at 257. The factual complexity of the case makes it difficult to isolate any one reason why the court felt the target directors' response was unreasonable. Any of the following factors may have been determinative: (1) the plan had not been implemented with due care; (2) the plan was designed to deter the proxy fight, not to protect the shareholders against an unfair tender offer; (3) the target's flippant attitude that once it had identified some vague threat, any response to elimi- 
As a result, the second prong of the Unocal test is easily met and provides a weak standard of review. ${ }^{69}$

\section{Unocal's new standard of review seems particularly superficial}

nate this threat was per se reasonable; (4) abundant evidence that the board decided to fight the tender offer without examining the impact the tender offer would have on target shareholders; or (5) the court's hostility to this poison pill, which it felt would probably not help the target shareholders under any scenario but rather was likely to hurt them. Id. at 253-59.

Second, in AC Acquisitions Corp. v. Anderson, Clayton Co., 519 A.2d 103 (Del Ch. 1986), the Delaware Chancery Court held that a target's self-tender used to block a hostile offer was not a reasonable response to a hostile tender offer because the selftender was coercive. Id. at 114. This holding that the board's action failed prong two of the Unocal test becomes more intelligible by focusing on prong one. Using the prong one standard, the court found that the third party offer was not a real threat to the corporation or its shareholders because it was a fair offer. $I d$. Thus, in its prong two analysis, the court was concerned about a defensive tactic, a self-tender, that would preclude a fair third party offer. The court justified the defensive tactic, however, because it allegedly was designed to give the shareholders two options: the third party offer and the self-tender. Id. at 116. In essence, the court held that while the target could give the shareholders a choice between two offers, it could not preclude and replace a fair third party offer with an offer of its own:

A board need not be passive, . . . even in the face of an any-and-all cash offer at a fair price with an announced follow up merger offering the same consideration. But in that special case, a defensive step that includes a coercive self-tender timed to effectively preclude a rational shareholder from accepting the any-and-all offer cannot, in my opinion, be deemed to be reasonable in relation to any minimal threat posed to stockholders by such offer.

Id. at 114 (citation omitted). Thus, the court determined that the target board satisfied the first prong by creating an alternative for the shareholders but then found that the target failed in the second prong because the alternative self-tender offer did not leave the shareholders with any real choice. Id. at ll4. The court felt that the target structured the self-tender in such a way that the target stockholders would feel coerced into accepting the self-tender, rather than the third party tender offer. Id. at 115 . Thus, the defensive tactic that was to provide the shareholders with an alternative served instead to preclude the target stockholders' choosing the third party tender offer.

In Norlin Corp. v. Rooney, Pace, Inc., 744 F.2d 255 (2d Cir. 1984), decided before Unocal, the Second Circuit found that the plaintiff met its burden of establishing the directors' self-dealing in issuing stock to an employee stock option plan by proving that the directors' actions were not fair and reasonable. Id. at 266-67. When the burden switched to the directors, they failed to show that they created the plan to benefit employees. The court found:

[T] he ESOP was created solely as a tool of management self-perpetuation. It was created a mere five days after the district court refused to enjoin further stock purchases by [the bidder] and at a time when Norlin's officers were clearly casting about for strategies to deter a challenge to their control. No real consideration was received from the ESOP for the shares. The three trustees appointed to oversee the ESOP were all members of Norlin's board, and voting control of all of the ESOP shares was retained by the directors. We therefore conclude that ... the transfer of stock to the ESOP was part of a management entrenchment effort.

Id. (footnotes omitted).

${ }_{69}$ But see supra note 63 (some scholars argue that courts will subject defensive tactics to a real review). 
when applied to anticipatory defensive tactics implemented before any offer is on the horizon. The courts cannot realistically evaluate the reasonableness of the directors' response to an abstract threat. Arguably, such preplanned tactics demonstrate the directors' conflict of interest even more clearly than do reflexive responses because preplanned tactics make it more difficult for the target to be acquired before the identity of the bidder or the offering price is even known. ${ }^{70}$ Yet, the Delaware Supreme Court has said that anticipatory defensive tactics deserve greater protection than do defensive tactics instituted under the pres-

${ }^{70}$ Some corporations argue that anticipatory defensive tactics are appropriate because the directors are concerned about any offers, potential or actual. In Moran, for example, the target, Household, argued that the stock was undervalued in relation to the break-up value of the corporation. 500 A.2d at 1349. Thus, the directors of Household perceived the corporation was particularly vulnerable to two-tiered, junk bond financed "bust-up" tender offers. Id. at 1356-57. Although the directors considered seeking shareholder approval for shark repellent charter amendments, they decided to implement a poison pill plan that did not require shareholder approval. Id. at 1349 .

Others have argued that preplanned tactics give target management more power to negotiate a better deal for their shareholders when an offer appears. See Oesterle, supra note 30, at 122-23 (discussing study indicating that target managers who, though not opposed to all control changes, resist an offer, obtain higher premiums for their shareholders); see also Jarrell, The Wealth Effects of Litigation by Targets: Do Interests Diverge in a Merger?, 28 J.L. \& ECON. 151, 151-77 (1985) (presenting analysis of 103 takeover targets discussed by Oesterle). Oesterle reasoned that the Revlon board's defensive tactics served not only to cause the initial bidder to increase its offer substantially but also to attract a competing bid. Oesterle, supra note 30 , at $149 ; c f$. Buxbaum, supra note 24, at 1708-09 (arguing that while certain preplanned defensive tactics are occasionally justified in the hostile tender offer setting so that target directors will have some flexibility in dealing with takeover attempts, such considerations have no place in the less hurried situation of a statutory merger).

Whether target directors should enact defensive tactics in these or any circumstances is the central issue in the debate on the propriety of defensive tactics in general. Noted scholars such as Easterbrook, Fischel, Gilson, and Bebchuck would argue against such tactics. If the target's low stock price is evidence of poor management, management should not be permitted to entrench itself in the corporation through defensive tactics. See Bebchuck, The Case for Facilitating Competing Tender Offers: A Reply and Extension, 35 STAN. L. REv. 23, 28 (1982) [hereinafter Bebchuck I] (stating that the market may detect poor management, creating potential for beneficial acquisition); Easterbrook \& Fischel, Auctions and Sunk Costs in Tender Offers, 35 Stan. L. Rev. 1, 1-2 (1982) [hereinafter Easterbrook \& Fischel II] (arguing that both investors and society benefit if management does not resist takeover bids); Gilson, Seeking Competitive Bids Versus Pure Passivity in Tender Offer Defense, 35 Stan. L. REv. 51, 62 (1982) [hereinafter Gilson II] (contending that competitive bidding allocates assets to those who use them most efficiently).

On the other hand, noted merger and acquisition expert, attorney Martin Lipton, argues that such tactics should fall within the business judgment rule. Lipton, Takeover Bids in the Target's Boardroom: A Response to Professors Easterbrook and Fischel, 55 N.Y.U. L. REv. 1231, 1235 (1980) (contending that directors' passivity in the face of tender offers has a "devastating impact on long-term planning"). Many courts have agreed with Mr. Lipton. See supra notes 37-40, 44 and accompanying text. Moreover, many state legislatures have legitimized anticipatory tender offer defensive tactics. See infra note 105 (discussing various state antitakeover statutes). 
sures of a takeover bid because the court believed the lack of pressure would increase the likelihood that the directors would exercise reasonable judgment. ${ }^{\text {11 }}$

Once the directors have satisfied Unocal's requirements, ${ }^{72}$ the burden of proof shifts to the plaintiffs who must show, by a preponderance of the evidence, that the directors' decisions were either: (1) motivated by a lack of good faith; (2) made without adequate information; (3) primarily based on perpetuating themselves in office; (4) fraudulent; or (5) overreaching. ${ }^{73}$ The first two of these criteria-lack of good faith and lack of adequate information-effectively are settled when the directors satisfy their burden of proof. Similarly, it seems unlikely that plaintiffs will ever be able to establish the third criterion, which is that job security was the primary factor motivating the directors' decision, because the court already will have resolved that issue when it accepted the directors' argument that the takeover endangered corporate policy. ${ }^{74}$ Only the last two criteria-proving by a preponderance of the evidence that the defendants' activities were either fraudulent or overreaching-are viable options after the directors have met their burden. These remaining two factors, however, are the same stringent criteria that existed before the Unocal court articulated its new standard of review. ${ }^{75}$

71 Moran, 500 A.2d at 1350 . The court's logic ignores the arguments made above that preplanned tactics demonstrate a greater conflict of interest. See supra text accompanying note 70 . One commentator has argued that Moran watered down the Unocal test because the Moran court held that Unocal's test was satisfied even when there was no threat. See Note, supra note 55, at 669-70. The Moran court also failed to consider the reasonableness of the defensive actions in light of the lack of an immediate particular threat. $I d$.

${ }_{72}$ If the defendants fail to meet either of the two prongs of the Unocal test, the business judgment rule does not apply. In that event, the defendants have the burden of proving that the transaction was objectively or intrinsically fair, as opposed to showing an honest belief that the transaction was entirely fair. See Johnson v. Trueblood, 629 F.2d 287, 293 (3d Cir. 1980) (finding that under Delaware law, once plaintiff showed directors' primary purpose was to retain control, directors had burden of proving transaction had valid corporate purpose), cert. denied, 450 U.S. 999 (1981); AC Acquisitions Corp. v. Anderson, Clayton \& Co., 519 A.2d 103, 115 (Del. Ch. 1986) (stating that "where the entrenchment effect of the ... [defensive tactic] creates a species of director interest ... the failure to qualify for the protections of the business judgment rule means that all aspects of the transaction must be deemed fair to shareholders (regardless of subjective intent) to be sustained").

${ }_{73}$ See Unocal, 493 A.2d at 958.

74 For cases where courts held that a director's mixed motive did not constitute a violation of the duty of loyalty, see Panter v. Marshall Field Co., 646 F.2d 271, 294-95 (7th Cir.), cert. denied, 454 U.S. 1092 (1981); Treadway Cos. v. Care Corp., 638 F.2d 357, 378 (2d Cir. 1980); Trueblood, 629 F.2d at 292; Whittaker Corp. v. Edgar, 535 F. Supp. 933, 950-51 (N.D. Ill. 1982). See also Fiduciary Duties, supra note 57, at 2324 (discussing "sole or primary purpose" test that courts use when looking at directors' mixed motives).

${ }^{75}$ See supra notes $37-40$ and accompanying text (discussing plaintiff's traditional burden of proof in corporate control cases). 
In sum, the Delaware Supreme Court has explicitly acknowledged that target directors in a hostile takeover have a conflict of interest and has required the directors formally to initially prove that their decisions were made for corporate, rather than personal, reasons. ${ }^{76}$ In theory and as applied, however, Unocal's loyalty tests are superficial. The only substantive aspect of the Unocal test is that the directors fulfill their duty of care, and that standard is easily met by devoting time and attention to making the decision. The Unocal test is thus unresponsive to target shareholders' concerns because it is the directors' loyalty to the corporation, not their care, that is at issue. ${ }^{77}$ Recent Delaware Supreme Court rulings regarding defensive tactics evidence that in fighting tender offers almost anything will pass muster, despite the new standard of review.

If judicial review of tender offer defensive tactics has been an ineffective monitor of the conflict of interest that faces inside target directors, that same weakness can be expected in judicial review of merger rejection cases. The courts that apply the business judgment rule or the Unocal test in tender offer cases will most likely use the same standards

${ }^{76}$ Unlike Delaware, New York has not shifted the burden of proof to the directors. See Hanson Trust PLC v. ML SCM Acquisition, Inc., 781 F.2d 264, 273 (2d Cir. 1986) (noting that plaintiffs would fare better in Delaware).

${ }_{77}$ For other examples in which the Delaware Supreme Court has subsumed what should have been a duty of loyalty analysis into a duty of care analysis, see Gilson I, supra note 13, at 828-29 (discussing Cheff v. Mathes, 41 Del. Ch. 494, 508, 199 A.2d 548 (1964)); infra notes 98-104 and accompanying text (discussing Revlon, Inc. v. MacAndrews \& Forbes Holdings, 506 A.2d 173 (Del. 1986), and Hanson Trust PLC v. ML SCM Acquisition, Inc., 781 F.2d 264 (2d Cir. 1986) using duty of care analysis for what appears to be duty of loyalty issues). But see Norlin Corp. v. Rooney, Pace, Inc., 744 F.2d 255, 265 (2d Cir. 1984) (recognizing that "[o]nce self-interest or bad faith is demonstrated, the duty of loyalty supersedes the duty of care"); Plaza Sec. Co. v. Fruehauf Corp., 643 F. Supp. 1535, 1543 n.6 (E.D. Mich. 1986) (following Norlin); Terrydale Liquidating Trust v. Barness, 642 F. Supp. 917, 919 (S.D.N.Y. 1986) (same).

There are several possible explanations as to why an inquiry that primarily raises the issue of the directors' loyalty has been changed into an issue of the directors' care. One is that care is an easier matter for the courts to examine. See Siegel, supra note 27, at 390-92 (court's review of tangible factors in duty of care analysis is easier than evaluating the directors' loyalty). The other, more cynical view is that recent amendments to corporate statutes eliminate the directors' liability for monetary damages for most violations of their duty of care but not for violations of their duty of loyalty. See, e.g., DEL. CODE ANN. tit. 8, § 102(b)(7) (Supp. 1986) (allowing corporations to limit monetary damages in certificate of incorporation for directors' liability resulting from most violations of their duty of care); ALI, Principles of Corporate Governance: ANalysis and Recommendations $\S 7.17$ (a) (Tent. Draft No. 7, 1987) (recommending a ceiling on liability for duty of care violations). As a result, a court could find a violation of the directors' duty of care without exposing them to any monetary damage. Note, however, that this statutory provision was not yet in effect in Delaware when Unocal, 493 A.2d 946, Moran, 500 A.2d 1346, and Revlon, 506 A.2d 173, were decided. 
if shareholders challenge their directors' rejection of a merger. Either test will result in poor monitoring of the inside target directors' compliance with their duty of loyalty. In fact, the courts are likely to be even more deferential to a board's decision to reject a merger than to a board's decision to fight a tender offer because the corporate statutes give the directors unilateral blocking power to reject a merger ${ }^{78}$ but are relatively silent ${ }^{79}$ as to the directors' role in a tender offer. The courts are likely to be at least as deferential to management's prerogative in this instance as they are in the tender offer area.

\section{Merger Acceptance Situations}

There are few merger cases in which shareholders challenge target directors' resolutions recommending approval of a merger proposal. ${ }^{\mathbf{8 0}}$ The scarcity of litigation can be attributed to the fact that shareholders who approve a merger are not inclined to challenge it, and those who oppose the merger may find their appraisal rights ${ }^{81}$ either preferable or

78 See supra notes $18 \& 21$ and accompanying text (discussing statutory requirement that directors pass a resolution recommending a merger).

${ }^{7 \theta}$ But see infra note 105 (discussing state antitakeover statutes).

${ }^{80}$ See Samjens Partners I v. Burlington Indus., Inc., 663 F. Supp. 614, 616 (S.D.N.Y. 1987) (plaintiff stockholder, who was also the tender offeror, challenged target directors' approval of a merger agreement with a third party on multiple grounds, including breach of target directors' fiduciary duties to target shareholders); Smith v. Van Gorkom, 488 A.2d 858, 881 (Del. 1985) (classifying directors' procedures in agreeing to a merger as grossly negligent); cf. Pupecki v. James Madison Corp., 376 Mass. 212, 229, 382 N.E.2d 1030, 1035 (1978) (reversing superior court's granting of motion to dismiss plaintiff/shareholder's allegation that corporation sold substantially all of its assets for inadequate consideration plus compensation for controlling shareholder in the form of employment and noncompetition agreements).

Most challenges to board resolutions recommending mergers are parent/subsidiary mergers. See, e.g., Rosenblatt v. Getty Oil Co., 493 A.2d 929, 937 (Del. 1985) (challenging the fairness of merger with parent company); Weinberger v. UOP, Inc., 457 A.2d 701, 703 (Del. 1983) (minority shareholders brought action to invalidate freezeout merger between parent and subsidiary); Singer v. Magnavox Co., 380 A.2d 969, 972 (Del. 1977) (minority shareholders brought action alleging that parent corporation breached its fiduciary duty when it effectuated a merger transaction with its subsidiary); Tanzer v. International Gen. Indus., Inc., 379 A.2d 1121, 1123 (Del. 1977) (minority shareholders of subsidiary brought action to invalidate freeze-out merger). For a discussion of merger decisions challenged by competing bidders, see infra notes 178-79 and accompanying text.

81 The appraisal remedy is a statutory right that enables shareholders who object to certain extraordinary transactions to require the corporation to buy their shares for cash if the shareholder dissents from the transaction. See, e.g., DEL. CODE ANN. tit. 8, $\S 262$ (1983); VA. CODE ANN. $\S 13.1-730$ (1986). Appraisal has become a more attractive alternative for shareholders who oppose a merger since the Delaware Supreme Court held that all relevant factors affecting price must be considered in the valuation process. See Weinberger, 457 A.2d at 713; see also Siegel, supra note 27, at 405-06 n.146 (discussing change in appraisal method set forth in Weinberger). 
required in lieu of litigation. ${ }^{\mathbf{8 2}}$ Judicial reaction to a target board's resolution recommending a merger can be predicted, however, from analogous tender offer cases where a target board acts receptively to a tender offer. In both scenarios, where the target is for sale, target management's acquiescence to the sale may have been "purchased" by the bidder. ${ }^{8 s}$

Courts have invalidated tender offer defensive tactics in the "forsale" tender offer setting primarily because the Unocal test is inapplicable and a more rigorous standard is applied. In Revlon, Inc. $v$. MacAndrews $\mathcal{E}$ Forbes Holdings, Inc., ${ }^{84}$ the Delaware Supreme Court said:

The Revlon board's authorization permitting management to negotiate a merger or buy-out with a third party was a recognition that the company was for sale. The duty of the board had thus changed from the preservation of Revlon as a corporate entity to the maximization of the company's value at a sale for the stockholders' benefit. This significantly altered the board's responsibilities under the Unocal standards. It no longer faced threats to corporate policy and effectiveness, or to the stockholders' interests, from a grossly inadequate bid. The whole question of defensive measures became moot. The directors' role changed from defenders of the corporate bastion to auctioneers charged with getting the best price for the stockholders at a sale of the company. ${ }^{85}$

Revlon clearly mandates that once a board decides to sell the corporation, it must attempt to maximize price. ${ }^{\mathbf{8 6}}$ The Delaware Supreme

82 Some statutes prevent shareholders from challenging a transaction, except on grounds of fraud, when appraisal rights are available. VA. CODE ANN. § 13.1730(4)(B)(1986); RMBCA, supra note 3, § 13.02(b).

${ }_{83}$ Aside from the comparable conflict issues, see supra notes 14,34 , mergers and tender offers are further related because some mergers may be tender offer defensive tactics. For example, a corporation might accept a merger offer in order to avoid a hostile, or potentially hostile, takeover. See, e.g., Hanson Trust PLC v. ML SCM Acquisition, Inc., 781 F.2d 264, 267-72 (2d Cir. 1986) (target corporation sought merger with third party to avoid hostile tender offer); Crouse-Hinds $\mathrm{Co}$. v. Internorth, Inc., 634 F.2d 690, 692 (2d Cir. 1980) (target management proposed merger with one party to defeat tender offer by another party); Revlon, Inc. v. MacAndrews \& Forbes Holdings, Inc., 506 A.2d 173, 178 (Del. 1986) (target corporation entered into merger agreement with third party to thwart hostile tender offer).

84506 A.2d 173 (Del. 1986).

Bs $I d$. at 182.

${ }^{88}$ Id. 
Court in Revlon disallowed a lock-up, ${ }^{87}$ a cancellation fee, ${ }^{88}$ and a noshop ${ }^{88}$ provision in a white knight ${ }^{90}$ merger agreement because these provisions thwarted, instead of promoted, competitive bidding for the target. ${ }^{91}$ The Second Circuit in Hanson Trust PLC v. ML SCM Acquisition, Inc. ${ }^{92}$ disallowed a lock-up for the same reason. ${ }^{93}$

Revlon not only requires directors to maximize price once the company is for sale but also makes clear that the directors' sole responsibility is to find a price that benefits their shareholders. ${ }^{94}$ In particular, the court in Revlon found that the directors' actions, which favored a white knight over a competing tender offeror, benefited target noteholders at the expense of the shareholders. ${ }^{95}$ The court decided that the

${ }^{87}$ Id. at 184-85. A lock-up is an option to buy shares or assets of the target company. A target will give this option to a third party for one of two reasons: (1) in the hope of so disadvantaging another suitor as to prevent, or at least make more difficult, that suitor's bid for the target, or (2) to induce a friendly third party, through benefits provided by the lock-up, to bid or negotiate for the target. See Fiduciary Duties, supra note 57, at 80; infra notes 131, 212-23, 362-69 and accompanying text (discussing lock-ups).

${ }^{88}$ Revlon, 506 A.2d at 184 . A cancellation fee provides liquidated damages to the bidder in the event the acquisition fails to close. See infra notes 132, 370-74 and accompanying text (discussing cancellation fees).

${ }_{89}$ Revlon, 596 A.2d at 184 . A no-shop provision prevents the target from seeking or negotiating with another bidder. See infra notes 130, 188-211, 350-61 and accompanying text (discussing no-shop covenants).

${ }_{80} \mathrm{~A}$ "white knight" is a friendly acquirer sought by the target company in response to a hostile bidder's tender offer. See supra note 83 (discussing mergers as a tender offer defensive tactic).

91 Revlon, 506 A.2d at 183-84. It is noteworthy that the court held that none of these provisions was per se illegal, but only invalid in this particular context. See id. at 183; $c f$. Freedman v. Restaurant Assocs. Indus., Inc., No. 9212 (Del. Ch. October 16, 1987) (plaintiff unsuccessfully attempted to use Revlon principles to get injunction ordering board to take affirmative action, in for-sale context, to maximize returns to the shareholders).

${ }^{82} 781$ F.2d 264 (2d Cir. 1986).

83 Id. at 274.

94 Revlon, 506 A.2d at 182. The court in Revlon held that a board may consider interests of other constituencies "provided there are rationally related benefits accruing to the stockholders." Id. at 182-83; see also Edelman v. Fruehauf Corp., 798 F.2d 882, 885 (6th Cir. 1986) (finding that the directors' actions "were not taken in a good faith effort to negotiate the best deal for the shareholders"); Samjens Partners I v. Burlington Indus., Inc., 663 F. Supp. 614, 625 (S.D.N.Y. 1987) (upholding target's merger agreement, which included a no-shop clause and a cancellation fee, because it increased the value to their shareholders by $\$ 6$ per share over the original tender offer bid).

${ }^{88}$ The original bidder for Revlon said it would top any offer made by Revlon's white knight. Revlon, 506 A.2d at 178. Revlon's shareholders, therefore, would have to receive a better price from the original bidder than from the white knight. Nevertheless, Revlon's board gave substantial concessions to ensure the success of the offer from its white knight rather than that of the original bidder. Id. at 178-79. The Revlon directors favored the white knight partly because it promised to shore up the value of the Revlon notes by exchanging the old notes for new notes. Id. The court in Revlon said that the directors' "concern for non-stockholder [the noteholders'] interests is inappropriate when an auction among active bidders is in progress, and the object no longer is to protect or maintain the corporate enterprise but to sell it to the highest bidder." Id. at 182. See infra text accompanying note 96 and accompanying text (discussing directors' concern over possibility of liabilitv). 
directors so acted because they were afraid of being held liable to Revlon's noteholders. ${ }^{98}$ As a result, the court concluded that the directors had a conflict of interest between acting in their own interest and serving the best interests of their shareholders. ${ }^{97}$

Given that the Revlon court determined that the directors had a conflict of interest, it is somewhat surprising that the court found the directors violated their duty of care, not their duty of loyalty. ${ }^{98}$ Similarly, in Hanson, the Second Circuit held that the target board, SCM, had breached its duty of care ${ }^{\theta \theta}$ in granting a lock-up to its white

(6) When the value of the notes dropped, the directors were afraid that the noteholders would sue. Revlon, 506 A.2d at 178-79. The purchasers of the notes were former Revlon shareholders who had exchanged their stock for these failing notes on the recommendation of their directors. Id. at 177. The court concluded, however, that as the noteholders' rights were fixed, the Revlon board had no further obligation to its noteholders. Id. at 182-83.

97 The court reasoned that the Revlon directors were motivated by a conflict of interest: "The principal benefit went to the directors, who avoided personal liability to a class of creditors to whom the board owed no further duty under the circumstances." Id.

98 Id. In fact, the lower court had concluded that the directors violated their duty of loyalty. MacAndrews \& Forbes Holdings v. Revlon, Inc., 501 A.2d 1239, 1250 (Del. Ch. 1985), aff'd on other grounds, 506 A.2d 173 (Del. 1986).

90 Hanson, 781 F.2d at 283 . Note that the standard of due care is different in the Second Circuit from the standard in Delaware. In Hanson, although finding that the directors violated their duty of care under the standard in the Second Circuit, the court remarked that the directors' conduct did not rise to the level of gross negligence, the standard used in Delaware. Id. at 275.

It is also interesting to note that in analyzing whether the directors fulfilled their duty of care, the court in Hanson did not find it dispositive that the target board relied on the advice of outside legal counsel and an investment banker. Id. Primarily, the court thought the investment banker, Goldman Sachs, did a poor, or at least incomplete, job and that obtaining this advice was not a substitute for the board's responsibility to familiarize itself with the relevant facts. $I d$. The court stated:

[T] he SCM directors, in a three-hour late-night meeting, apparently contented themselves with their financial advisor's conclusory opinion that the option prices were 'within the range of fair value,' although had the directors inquired, they would have learned that Goldman Sachs had not calculated a range of fairness. There was not even a written opinion from Goldman Sachs as to the value of the two optioned businesses. Moreover, the Board never asked what the top value was or why two businesses that generated half of SCM's income were being sold for one third of the total purchase price of the company under the second LBO merger agreement, or what the company would look like if the options were exercised. There was little or no discussion of how likely it was that the option 'trigger' would be pulled, or who would make that decision-Merrill, the Board, or management.

Id. The court in Hanson also delineated several other reasons why it believed the directors were not careful in granting a lock-up. Id. at 277-79; see also Norlin Corp. v. Rooney, Pace, Inc., 744 F.2d 255, 265-67 (2d Cir. 1984) (listing requirements that board must meet when invoking employee stock option plan so as to satisfy duty of loyalty); Treadway Cos., Inc. v. Care Corp., 638 F.2d 357, 384 (2d Cir. 1980) (setting forth steps that are predicates for finding due care), cited in Hanson, 781 F.2d at 275. 
knight, Merrill Lynch, which had joined with SCM management to attempt a leveraged buy out of SCM. ${ }^{100}$ The court enumerated several reasons why it felt that the directors had violated their duty of care: (1) the directors granted the lock-up without adequate information about either the amount of the discount or the effect of the lock-up on SCM; ${ }^{101}$ (2) the directors gave a substantial discount on the assets that were the subject of the lock-up, and in return, received only a marginal increase in price from the management group; ${ }^{\mathbf{1 0 2}}$ and (3) the lock-up effectively ended the auction for SCM instead of promoting it. ${ }^{103}$ Thus, the court found the directors did not act carefully. Note, however, that the case involved target directors with a strong self-interest in a leveraged buy out. The court, while clinging to a duty of care analysis, actually examined the directors' loyalty. In effect, the court found that the high degree of self-interest required the directors to be especially careful in choosing a defensive tactic. ${ }^{104}$

The courts, therefore, have tolerated tender offer defensive tactics once the target is for sale only if the tactics are designed to secure the best price for the target shareholders. Thus, in the for-sale cases, the courts accepted only those defensive tactics that encouraged bidders. The courts, however, have analyzed these cases under a duty of care, rather than a duty of loyalty, analysis. Courts may similarly ignore concerns about the directors' duty of loyalty in merger acceptance cases, which closely parallel the for-sale tender offer setting.

\section{Effect of Judicial Decisions on the Structural and Market Monitors}

The foregoing discussion demonstrated that the courts have not chosen to monitor the wisdom of the target directors' decisions in corpo-

100 Hanson, 781 F.2d at 268-72. For a discussion of leveraged buy outs, see Booth, Management Buyouts, Shareholder Welfare, and the Limits of Fiduciary Duty, 60 N.Y.U. L. REv. 630 (1985).

The Revlon and Hanson courts differed in allocating the initial burden of proof and in defining the level of negligence that constitutes a violation of the directors' duty of care. Compare Revlon, $506 \mathrm{~A} .2 \mathrm{~d}$ at 180 (burden on directors to show good faith and reasonable investigation) with Hanson, 781 F.2d at 273 (burden on plaintiffs to rebut presumption of propriety that inures to the benefit of the directors). Nevertheless, both the Revlon and Hanson courts reviewed the process during which the directors decided to employ their respective lock-ups. Only after the courts found the decisionmaking process to be deficient because the directors did not exercise due care did the courts refuse to defer to the directors' judgment about the value assigned in the lock-ups. See Hanson, 781 F.2d at 278-81; Revlon, 506 A.2d at 182-84.

${ }^{101}$ Hanson, 781 F.2d at $278-80$.

102 Id. at 281-82.

103 Id. at 282-83.

104 See id. at 277. 
rate control transactions and are only ineffective monitors of the directors' loyalty. Far from solving the problem, the courts sometimes accentuate it by sanctioning defensive tactics that indirectly interfere with both the structural and market monitors that would otherwise check the inside directors' conflict of interest. ${ }^{105}$

${ }^{105}$ In addition, certain defensive tactics have been approved by state legislatures. Recent state antitakeover statutes, legitimized in part by the Supreme Court in CTS Corp. v. Dynamics Corp., 107 S. Ct 1637 (1987), sanction various defensive tactics that may hinder hostile acquisitions. In CTS, the Supreme Court upheld Indiana's Control Share Acquisition Statute, IND. Code ANN. § 23-1-42-1 to -42-11 (West Supp. 1987), against preemption and commerce clause challenges. See CTS, 107 S. Ct. at 1652. "The practical effect of . . . [the challenged Act was] to condition acquisition of control of a corporation on approval of a majority of the preexisting disinterested shareholders." Id. at 1641 .

Control share acquisition statutes have proliferated in the wake of the CTS decision. See, e.g., Control Share Acquisitions--Regulation Act of July 21, 1987, ch. 272, 1987 Mass. Adv. Legis. Serv. 200 (Law. Co-op.); Corporate Take-Over and Shareholder Protection Act of June 25, 1987, ch. 1, 1987 Minn. Sess. Law Serv. 911 (West); Act of May 13, 1987, ch. 182, 1987 N.C. Adv. Legis. Serv. 48; Fla. H.B. 358, § 607.109 (1987); Mo. H.B. 349, 84th Gen. Ass., lst Sess. $§ \$ 351.015$ to .690 (1987). Similar provisions had previously been adopted by other states, see, e.g., Haw. REv. STAT. $\S 416-172$ (1985) (preventing even the acquisition of control shares absent approval by majority of shares); Mo. ANN. STAT. $§ 351.407$ (Vernon Supp. 1987) (same); OHIo REv. Code ANN. § 1701.831 (Anderson 1985) (same), and are under serious consideration elsewhere, see, e.g., Takeover Game: Legislature Wants to Set the Rules, L.A. Daily J., May, 20, 1987, at 1, col. 6, 1, col. 6 (identifying 20 antitakeover bills, including control share acquisition bill, now pending in California legislature); see also SEC Pre-Emption Idea Gets Plaudits, Nat'l L.J., October 5, 1987, at 2, col. 2 (since CTS, nine states have passed antitakeover statutes, bringing the total to 26).

Control share acquisition statutes, while uniformly requiring shareholder approval to exempt an acquisition from the statutory restrictions, also give target directors the power to encourage or inhibit a particular tender offer. Explicit in many statutes is the directors' power to opt in or out of the statute, see, e.g., IND. CODE ANN. $\S 23-1-42-5$ (West Supp. 1987) (election may be contained in bylaws which directors can unilaterally amend), to control the timing of the shareholders' meeting, see, e.g., id. $\S 23-1-42-$ 7 (b) (directors can set shareholders' meeting up to 50 days after request), and to give their recommendations to the shareholders, see, e.g., id. $\S 23-1-42-8(b)(2)$ (requiring that a statement by the board of directors of its position or recommendations or that it is taking no position with respect to the control share acquisition accompany the notice of a shareholders' meeting). Moreover, most control share acquisition acts do not apply to acquisitions accomplished through merger agreements in which target directors have acquiesced. See, e.g., id. \& 23-1-42-2(d)(5) (acquisition of shares is not a control share acquisition if pursuant to a plan of merger or plan share exchange). While the merger exemption technically covers only statutory mergers and share exchanges, it may apply as well to friendly tender offers undertaken pursuant to an agreement of merger. See Samjens Partners I v. Burlington Indus., Inc, 663 F. Supp. 614, 619 n.7 (S.D.N.Y. 1987) (plaintiff tender offeror claimed to be disadvantaged because North Carolina Control Share Acquisition Act, ch. 182, 1987 N.C. Adv. Legis. Serv. Pamphlet No. 2, at 48 (amending N.C. GEN. STAT. § 55), did not apply to tender offer undertaken by competing bidder pursuant to a merger agreement with the target directors). But see Romano, The Political Economy of State Takeover Statutes, 73 VA. L. REV. 111, 16970 (1987) (suggesting that control share acquisition statutes are the least effective of the state antitakeover statutes); Black, Why Delaware Is Wary of Anti-Takeover Law, Wall St. J., July 10, 1987, at 20, col. 3 (suggesting that control share acquisition statutes 
The statutory structure, which requires shareholder approval of any merger transaction, provides an objective monitor of the wisdom and loyalty of the directors' decision to recommend the merger proposal. If directors have made an unwise proposal or one that appears motivated by incentives provided by the bidding corporation to secure target management's approval, the shareholders can veto the transaction. ${ }^{108}$ In addition, the marketplace can monitor management's

may actually favor acquiring companies rather than target managers by requiring a shareholder vote).

Other kinds of state antitakeover statutes grant targets significant opportunities to thwart takeovers or to favor one bidder over another. For example, so called "fair price" statutes effectively eliminate two-tier tender offers by conditioning the secondstage merger upon a supermajority vote of shares and approval of the disinterested target directors or the payment of the same (highest) price to all shareholders. See, e.g., Conn. Gen. Stat. Ann. §§ 33-374(a)-(c) (West 1987); MD. Corps. \& Ass'ns Code ANN. §§ 3-601 to -603 (1985 \& Supp. 1986); Mich. Comp. Laws ANN. $\S \S 450.1776-.1784$ (West Supp. 1987); N.J. STAT. ANN. $\S \S 14 A: 10 A-3$ to -6 (West Supp. 1987); WASH. Rev. CODE ANN. § 23A.08.425 (Supp. 1987). Other state statutes contain variations or additions to the fair price or control share acquisition provisions, see, e.g., N.Y. Bus. CoRP. LAw $\S 912$ (McKinney 1986) (imposing a five-year freeze on business combinations between the target and acquiring companies unless approved by the disinterested target directors and allowing combinations after the five-year period only upon either the vote of the disinterested shares or compliance with a fair price rule); Corporate Take-Over and Shareholder Protection Act of June 25, 1987, ch. 1, 1987 Minn. Sess. Law Serv. 911 (West) (provisions regulating control shares, greenmail, and disclosure, coupled with a five-year freeze on second-stage mergers and authority for board to consider nonshareholder interests).

It is not clear if these legislative enactments significantly increase the defensive arsenal available to target directors under current judicial doctrines. See infra notes 44104 and accompanying text. Moreover, the statutes generally do not limit directors' powers either to hinder tender offers using defensive tactics or to promote a particular offer by granting asset or other lock-up options. See infra note 118 (discussing effect of state statutes on directors' fiduciary duties in the tender offer context).In any event, to the extent jurisdictional and substantive variations on the Indiana Control Share Acquisition statute also pass constitutional scrutiny, and to the extent the state antitakeover laws in general escape congressional preemption, see, e.g., H.R. 2668, 100th Cong., 1st Sess. (1987) (a tender offer reform bill that would, if enacted, overturn the CTS decision); SEC Should Have Authority to Preempt Some State Takeover Laws, Ruder Says, [July/Dec.] 19 Sec. Reg. \& L. Rep. (BNA), No. 37, at 1383 (Sept. 18, 1987) (testimony of SEC Chairman David Ruder before the House Energy and Commerce Telecommunications and Finance Subcommittee urging congressional preemption of state antitakeover laws), our proposal views the statutory provisions in the same light as defensive tactics sanctioned by judicial decisions.

For further descriptions of the various state antitakeover statutes, see Pinto, Takeover Statutes: The Dormant Commerce Clause and State Corporate Law, 41 U. Miami L. Rev. 473, 478-83 (1987); Romano, supra, at 113-20; Note, The Constitutionality of Second Generation Takeover Statutes, 73 VA. L. REv. 203, 207-11 (1987); Olson, Court Cuts Back on Securities Laws' Reach, Nat'l L.J., Aug. 17, 1987, at S-12 to $S-13$. For a discussion of the constitutional issues raised by the CTS decision, see Buxbaum, The Threatened Constitutionalization of the Internal Affairs Doctrine in Corporation Law, 75 CALIF. L. REv. 29, 29-36, $47-57$ (1987).

${ }^{108}$ See supra note 7 (examples of statutes requiring shareholder approval for a director-negotiated agreement); see also R. GILSON, THE LAW AND FINANCE OF CoR- 
merger recommendations by providing shareholders with alternative choices in the form of competing merger bids or tender offers. Competing bids can supply information regarding the fairness of the proposal recommended by target management, and may even indicate whether the recommended merger offer diverted money from the shareholders to their managers. ${ }^{\mathbf{1 0 z}}$

In merger rejection cases, however, the structural monitor shortcircuits because the shareholders are not given the opportunity to vote. ${ }^{108}$ Nevertheless, shareholders are entitled to have their directors' merger rejection decision made in compliance with their fiduciary du-

PORATE ACQUisitions 845 (1986) (asserting that the requirement that shareholders approve a merger or sale of assets acts as a check on a deal overly favorably to management).

${ }^{107}$ Gilson asserts that an offeror's ability to directly purchase stock from the shareholders in a tender offer acts to circumvent a management rejection of a merger or asset purchase offer rejected only because it was not favorable enough to management. R. GILSON, supra note 106, at 844-45. For an example of management allegedly acting in its own self-interest, see Barr v. Wackman, 36 N.Y.2d 371, 329 N.E.2d 180, 368 N.Y.S.2d 497 (1975). In Barr, the plaintiff, a shareholder of Talcott National Corporation, alleged in a derivative action that the defendants, Gulf \& Western, a Gulf \& Western subsidiary, and Talcott's directors, entered into an "agreement in principle," which was approved by both boards, for the merger of Talcott into Gulf \& Western for $\$ 24$ per Talcott share. Thereafter, Talcott's board abandoned the merger and instead approved a tender offer for Talcott at $\$ 20$ per share, made by a Gulf \& Western subsidiary. See id. at 374-75, 329 N.E.2d at 183-84, 368 N.Y.S.2d at 501-02. Plaintiff alleged that the Talcott board abandoned the merger at $\$ 24$ per share and approved a tender offer at $\$ 20$ per share because certain Talcott directors received personal and financial benefits as part of the tender offer "package." As part of this package, Talcott's chairman and chief executive was to keep his $\$ 125,000$ per year salary and become vice-chairman and consultant to the subsidiary, with an additional compensation of $\$ 575,000$ over 10 years. Moreover, a $\$ 340,000$ finder's fee in connection with the tender offer was to be paid to a corporation whose executive vice president was the chief executive's son. See id. at 375-76, 329 N.E.2d at 184, 368 N.Y.S.2d at 502-03. See also supra note 31 (discussing incentives to secure target management's cooperation in a corporate control transaction).

${ }^{208}$ The shareholders' only statutory power in this situation is their inherent, but perhaps illusory, right to replace the directors. Under some state statutes and the Model Business Corporation Act, removal of directors by shareholders is allowed with or without cause. See CAL. CoRP. CoDE $\S 303$ (West 1977) (directors may be removed with or without cause); DEL. CODE ANN. tit. 8, $\S 141(\mathrm{k})$ (1983) (directors may be removed with or without cause unless certificate of incorporation provides otherwise); MBCA, supra note $3, \S 39$ (directors may be removed, with or without cause, by a vote of the majority shareholders); RMBCA, supra note $3, \S 8.08$ (a) (directors may be removed with or without cause unless articles of incorporation provide for removal for cause only). But see N.Y. Bus. LAW $\$ 706$ (McKinney 1986) (requiring cause for removal unless the certificate of incorporation or bylaws provide for removal without cause). However, the constraints of the proxy solicitation process, which today substitutes for most shareholder meetings in public corporations, make unlikely any shareholder attempt to unseat the majority of the corporate board. Even institutional investors, whose interest in the corporation arguably is sufficient to justify the expense of a proxy contest, usually sell out rather than become more actively involved in management decisions. See Lowenstein, supra note 21, at 297-301. 
ties. The courts, however, have not efficiently monitored directors' decisions to resist a sale of the target. ${ }^{108}$ Nor have the Delaware courts been responsive to shareholders' claims that directors' implementation of tender offer defensive tactics effect a fundamental restructuring of corporate power from the shareholders to the directors because these tactics prevent shareholders from selling their stock in a tender offer. ${ }^{110}$

${ }^{109}$ See supra notes 98-104 and accompanying text.

110 See, e.g., Moran, 500 A.2d at 1353-54 (disagreeing with plaintiffs' assertion that the Rights Plan unlawfully changed Household's fundamental structure). The court in Moran rejected plaintiff's argument that the poison pill implemented without shareholder approval altered the balance in the corporate governance structure:

There is little change in the governance structure as a result of the adoption of the Rights Plan. . . . The contention that the Rights Plan alters the structure more than do other defensive mechanisms because it is so effective as to make the corporation completely safe from hostile tender offers is likewise without merit.

Id. at 1354. See infra note 111 and accompanying text (courts treat tender offer decisions as ordinary business decisions that fall within the realm of the directors', not the shareholders', role).

Other courts, however, have been more sympathetic to shareholders' claims that defensive tactics rework the corporate structure. One court enjoined the issuance of a stock dividend on the ground that it would redistribute voting rights within a class of stock:

Neither N.J.S.A. 14A:7-2 nor any other provision of the Business Corporation Act confer[s] upon the corporation or its directors the power to issue classes of shares which have differing voting rights within the same class or which modify previously issued classes of shares so as to confer different voting rights upon shares within that class. Asarco's series C Preferred Stock has this effect and consequently its issuance would be ultra vires and void.

Asarco Inc. v. M.R.H. Holmes A Court, 611 F. Supp. 468, 480 (D.N.J. 1985); see Norlin Corp. v. Rooney, Pace Inc., 744 F.2d 255, 258 (2d Cir. 1984) ("[T] he responsibility of the court is to insure that rules designed to safeguard the fairness of the takeover process be enforced. Our most important duty is to protect the fundamental structure of corporate governance. While the day-to-day affairs of a company are to be managed by its officers under the supervision of directors, decisions affecting a corporation's ultimate destiny are for the shareholders to make in accordance with democratic procedures."); see also Dynamics Corp. of Am. v. CTS Corp., 794 F.2d 250, 255 (7th Cir. 1986) (defensive tactics that do not require shareholder approval leave shareholders defenseless against their management), rev'd on other grounds, $107 \mathrm{~S}$. Ct. 1637 (1987); Hanson, 781 F.2d at 281 (reasoning that board had not justified propriety of their defensive tactic that impinged upon the shareholders' structural rights); accord, Amalgamated Sugar Co. v. N.L. Indus., 644 F. Supp. 1229, 1234-36 (S.D.N.Y. 1986) (court followed Asarco and granted preliminary injunction against board's adoption of voting rights plan as ultra vires under New Jersey law).

One author has argued that most cases concerning tender offer defensive tactics can be rationalized as expressing the courts' reluctance to allow a shift of voting power from the shareholders to management without the shareholders' approval. Mirvis, The Business Judgment Rule and Takeovers: Recent Developments in Takeover Defense, in Directors' and Officers' Liability 1986, A Review of THE Business JudgMENT Rule 489, 554 (Practicing Law Institute Course Handbook Series No. 525, 1986); see also Note, supra note 55, at 658 (arguing that Unocal is part of series of decisions, along with Aronson v. Lewis, 473 A.2d 805 (Del. 1984), and Weinberger v. 
Rather than protecting the shareholders' role in corporate control transactions, the Delaware courts have augmented the directors' power by treating decisions to reject an offer at a price above the market, without further negotiation, as an ordinary business decision: "The function of the court is not to define the terms of the negotiation in advance nor even to suggest further negotiation if, in the board's judgment, further negotiations with either party are not in the interests of the shareholders."111 Such reasoning, when combined with the directors' statutory powers, strongly suggests that target directors confronted with a merger offer will also have great leeway to reject the offer and keep the target independent. ${ }^{112}$ Such wide latitude in a context where the structural monitor is inoperative, gives target directors ample room to reject a merger proposal in their own self-interest.

Judicial sanctioning of defensive tactics has an even greater negative effect on the market monitor in a merger rejection context. When the target directors reject a merger offer for personal reasons, the bidder who attempts to detour the directors by making a tender offer directly to the target shareholders will find formidable roadblocks erected by the target's defensive tactics. ${ }^{113}$ Therefore, offerors must find a way to accommodate target management to prevent the target directors from implementing potent defensive tactics. Accommodating target management, however, feeds the directors' self-interest instead of monitoring it.

Once the target is for sale, courts have been more attuned to the

UOP, Inc., 457 A.2d 701 (Del. 1983), in which the Delaware Supreme Court increasingly scrutinizes the substance of decisions infringing on shareholders' rights). Similarly, one scholar has argued that "ownership claim issues" will receive increasing judicial scrutiny. See Manning, supra note 61, at 6; see also infra notes 215, 366-74 and accompanying text (discussing structural arguments in lock-ups and cancellation fees).

111 MacAndrews \& Forbes Holdings v. Revlon, Inc., 501 A.2d 1239, 1251 (Del. Ch. 1985), affd, 506 A.2d 173 (Del. 1986); see also Unocal, 493 A.2d at 954 ("When a board addresses a pending takeover bid it has an obligation to determine whether the offer is in the best interests of the corporation and its shareholders. In that respect a board's duty is no different from any other responsibility it shoulders, and its decisions should be no less entitled to the respect they otherwise would be accorded in the realm of business judgment."). But see Edelman v. Fruehauf Corp., 798 F.2d 882, 890 (6th Cir. 1986) (court required further negotiations with third party after invalidating management's leveraged buyout proposal).

112 The courts are unlikely to decrease the directors' power in a merger rejection situation simply because the shareholders have a statutorily-defined role. The shareholders' role is not triggered until the directors pass a resolution recommending a merger offer. See supra note 18 (giving examples of the role corporate statutes create for directors in a merger transaction).

11 See supra note 34 (discussing how directors in tender offers are creating blocking power equivalent to statutory merger role). See also supra note 105 (discussing formidable powers state antitakeover statutes grant to directors to accept or reject tender offers). 
desirability of permitting market forces to work. ${ }^{114}$ In these situations, the courts have warned target directors that their sole responsibility is to secure the best price possible for their shareholders. ${ }^{115}$ Only those defensive tactics implemented to attain this goal will be tolerated.

The judicial standards for monitoring defensive tactics in the forsale setting, while better than the standards used when the target is to be kept independent, are still troublesome. Despite language professing support for market forces, ${ }^{116}$ the courts' tolerance of even limited defensive tactics ${ }^{117}$ in these circumstances impedes the market monitor. ${ }^{118}$

114 A few courts believe the contest for corporate control should be decided in the marketplace. See Fiduciary Duties, supra note 57, at 26 (listing cases discussing this market theory). For instance, in Revlon, the Delaware Chancery Court felt that the poison pill substituted the board for the marketplace by allowing the board to choose among bids. $501 \mathrm{~A} .2 \mathrm{~d}$ at 1247. It is ironic that some courts are reluctant to interfere with target management's defensive tactics so that the market can function freely, when in fact these tactics interfere with the market. See Hanson, 774 F.2d at 60 (stating that preliminary injunctive relief to target "must be used with great care, lest the forces of the free market place, which in the end should determine the merits of takeover disputes, are nullified"); Warnaco, Inc. v. Galef, B-86-146, slip op. at 20 (D. Conn. March 3) ("The law of the market place should thus prevail."), affd by sum. order, 800 F.2d 1129 (2d Cir. 1986).

${ }_{116}$ See supra note 94 and accompanying text; see also Hanson, 781 F.2d at 281. In Hanson, the court required the corporation not only to act to secure the best price for its shareholders but also to let the shareholders decide their own fate. Id. The court reasoned that the board had not satisfied the "difficult task of justifying a lock-up option that is suspect for foreclosing bidding . . . and for thereby impinging upon shareholder decisional rights regarding corporate governance...." Id. (citations omitted). ${ }_{116}$ See supra notes 110, 115 (discussing belief of some courts that marketplace should decide tender offer contests).

117 While Revlon and Hanson disallowed all defensive tactics in a for-sale setting, see supra text accompanying notes 87-93, the court in Samjens Partners I v. Burlington Indus., Inc., 663 F. Supp. 614 (S.D.N.Y. 1987) allowed limited defensive tactics even though the company was for sale. See id. at 623-24; supra note 94 .

${ }_{118}$ One would assume that traditional fiduciary duty standards would govern decisions by target directors to implement those aspects of the state antitakeover statutes that remain under the directors' control. See supra note 105. In merger rejection cases, however, the legislative standards should enable the directors more easily to demonstrate that their efforts to defeat an unwanted takeover complied with those duties. For example, the implementation of measures permitted by state statutes should presumptively pass the first prong of the Unocal test that the action taken to retain the independence of the target was in the corporate interest. See supra text accompanying note 48. This has been predetermined by the state legislature. The plaintiffs could still attempt to surmount the difficult hurdle posed by the Unocal test and prove that the directors' primary motive was job retention or that the decision constituted overreaching or fraud. See supra text accompanying note 50 . In the for-sale setting, however, the Revlon and Hanson principles should apply to the legislatively-sanctioned defensive tactics. For example, target directors should have to justify under fiduciary duty standards a decision to apply the statutory provisions in a manner that favored one bidder over a competitor. See also Black, supra note 105, at 20, col. 3 (noting that once a bidder makes an offer to acquire a target that is subject to a control share acquisition statute, the courts may prohibit either side from engaging in activities designed to prejudice the required shareholder vote). As Black suggested, such a prohibition would arguably extend to defensive tactics, such as poison pills, that might otherwise receive judicial 
Moreover, once the target is for sale, defensive tactics interfere with the structural monitor if the tactics are so punitive that shareholders cannot rationally refuse the directors' recommendation. ${ }^{119}$

In sum, the tender offer cases indicate that the courts deliberately refuse to second-guess the wisdom of the directors' decisions and only ineffectively monitor the directors' loyalty. ${ }^{120}$ Compounding the prob-

sanction.

${ }^{119}$ See infra notes 366-68 and accompanying text (discussing when merger covenants transform shareholders' vote into a mere formality).

120 Perhaps because they recognize their own ineffectiveness, some courts are encouraging outside directors to govern conflict of interest transactions by giving the outside directors' decisions in corporate control transactions a heightened presumption of propriety. See, e.g., Samjens, 663 F. Supp. at 624 (in applying Delaware law, court found relevant that the board was composed primarily of outside directors, negotiations were conducted by the senior outside director, and all relevant decisions were made by the outside directors who were advised by outside counsel and investment bankers); Polk v. Good, 507 A.2d 531, 537 (Del. 1986) ("[T] tors on the Texaco board, coupled with the advice rendered by the investment banker and legal counsel, constitute a prima facie showing of good faith and reasonable investigation."); Moran, 500 A.2d at 1356 (finding that proof that directors' action was reasonable was "materially enhanced . . where . . . a majority of the board favoring the proposal consisted of outside independent directors"); Unocal, 493 A.2d at 955 (proof of good faith and reasonable investigation "materially enhanced . . . by the approval of a board comprised of a majority of outside independent directors"). Delaware courts are impressed with the use of outside directors because without any conflicts, directors can exercise independent business judgment. For other cases discussing the importance of outside directors, see Panter v. Marshall Field \& Co., 646 F.2d 271, 294 (7th Cir.) (noting that presumption of good faith afforded by business judgment rule heightens when independent outside directors compose majority of board), cert. denied, 454 U.S. 1092 (1981); Enterra Corp. v. SGS Assocs., 600 F. Supp. 678, 685 (E.D. Pa. 1985) (same); Freedman v. Restaurant Assocs. Indus., Inc., No. 9212, slip op. at 21 (Del. Ch. Oct. 16, 1987) (noting that the committee of independent directors was "appropriately constituted, well advised and active"); Ivanhoe Partners v. Newmont Mining Corp., Nos. 9281, 9221 (Del. Ch. Oct. 15, 1987) (noting favorably that a majority of the board members who enacted defensive tactics were outside independent directors); Puma v. Marriott, 283 A.2d 693, 696 (Del. Ch. 1971) (noting that the sole interest of outside independent directors is "the furtherance of the corporate enterprise"). There appears to be no reason why Delaware would not apply its presumption with equal force in the merger area.

Other courts, however, seem less convinced that the outside directors can so easily negate the inherent conflict of interest. See, e.g., Hanson, 781 F.2d at 277 (finding that outside directors did not sufficiently protect shareholders' interests); see also Dynamics Corp. of Am. v. CTS Corp., 794 F.2d 250 (7th Cir. 1986), rev'd on other grounds, 107 S. Ct. 1637 (1987), in which the court held:

When managers are busy erecting obstacles to the taking over of the corporation by an investor who is likely to fire them if the takeover attempt succeeds, they have a clear conflict of interest, and it is not cured by vesting the power of decision in a board of directors in which insiders are a minority (five of CTS's eight directors are outsiders). No one likes to be fired, whether he is just a director or also an officer. The so-called outsiders moreover are often friends of the insiders. And since they spend only part of their time on the affairs of the corporation, their knowledge of those affairs is much less than that of the insiders, to whom they are likely therefore to defer. 
lem, judicial acceptance of tender offer defensive tactics has eroded the structural and market monitors of the directors' wisdom and loyalty in corporate control transactions. Given the statutory role of directors in mergers, courts are likely to grant at least equal deference to directors' merger decisions. Such a result would amplify the negative effect of the judicial decisions on the structural and market monitors of directors' merger decisions.

\section{Exclusive Merger Covenants}

\section{A. Introduction}

Thus far, our working model contemplates policing directors' merger decisions primarily through structural and market monitors. Even assuming merger decisions are made by directors who have no conflict of interest, our model must ensure that target directors do not take actions that sterilize the shareholders' role or that effectively eliminate options that the market may provide. It is commonly understood that while directors unilaterally run the corporation's ordinary business affairs, they do not have the unilateral power to effectuate a merger. ${ }^{121}$ Nevertheless, the presence of certain collateral covenants in board-negotiated merger agreements can vitiate the roles of both the shareholders and the market in a merger transaction.

Merger agreements are complex documents containing numerous covenants, conditions, and warranties, as well as the terms of the merger itself. ${ }^{122}$ Collateral covenants in merger agreements come in nu-

Id. at 256. For a discussion of the role of outside directors, see Pease, Outside Directors: Their Importance to the Corporation and Protection From Liability, 12 DEL. J. CORP. L. 25 (1987).

${ }^{121}$ See, e.g., Cal. Corp. Code $\S \S 1001,1201$ (West 1977 \& Supp. 1987); Del. Code ANN. tit. 8, §§ 251, 271 (1983); N.Y. Bus. CoRP. LAW $\S \S 903,909$ (McKinney 1986); MBCA, supra note 3 , $\S 73,79$; RMBGA, supra note $3, \S \S 11.03,12.02$.

${ }_{122} \mathrm{~J}$. Freund, a prominent practitioner and commentator in the negotiated merger field, describes the parts of a merger agreement as follows:

[Warranties] are a way of the seller (or buyer) saying: "Here is what my business is all about, at this particular moment in time."

. . Covenants are a way of saying: "Here is what we commit ourselves to do, and here is what we promise not to do, during the period between the date the agreement is signed and the closing."

... [Gonditions are] a way of saying: "Here is what you are entitled to get from me (or from others) at or prior to the closing. If you don't get it, you can walk away from the deal...."

J. Freund, supra note 6, at 153-57. A single undertaking can function as both a covenant and a condition. For example, the target may covenant to recommend that target shareholders approve the merger; such approval is then made an explicit precon- 
merous forms and are known by various nomenclatures. The most common and least controversial covenants concern routine housekeeping tasks necessary to complete most merger transactions. Such covenants include undertakings to: prepare SEG registration and proxy materials; ${ }^{\mathbf{1 2 3}}$ request tax rulings; ${ }^{\mathbf{1 2 4}}$ request Hart-Scott-Rodino clearances $^{128}$ or other governmental consents; ${ }^{126}$ provide financial informa-

dition to closing the transaction. See 17 C.F.R. $\$ \S 240.14 a-1$ to -13 (1987).

${ }^{123}$ If the target shares are to be acquired in exchange for shares of the acquiring company, this exchange must be registered pursuant to $\S 5$ of the 1933 Securities Act, 15 U.S.C. $\$ 77$ e (1982), unless an exemption can be found. See generally Interpretations of Rule 145, Securities Act Release No. 5463, 1 Fed. Sec. L. Rep. (CCH) If 3058 (Feb. 28, 1974); New Rules Relating to Business Combinations, Securities Act Release No. 5316, [1972-1973 Transfer Binder] Fed. Sec. L. Rep. (CCH) ף 79,015 (Oct. 6, 1972). Most exchange offers must be registered using Form S-4. See Adoption of Registration Form, Securities Act Release No. 6578, 6 Fed. Sec. L. Rep. (CCH) If 72,418 (Apr. 23, 1985). Furthermore, regardless of the form of consideration, the target directors must prepare proxy materials. If the target is of sufficient size, see $\S 12(\mathrm{~g})$ of the Securities Exchange Act of 1934,15 U.S.C. $\$ 781(\mathrm{~g})$ (1982) [hereinafter the 1934 Act], or has shares registered on a national exchange, see $\S 12(\mathrm{~b})$ of the 1934 Act, 15 U.S.C. $\S 781$ (b) (1982), the proxy materials must be filed and reviewed by the SEC. See $\S 14$ (a) of the 1934 Act, 15 U.S.C. § 78n (1982 \& Supp. III 1985); SEC Rules 14a-1 to -13 \& Schedule $14 A, 17$ C.F.R. $\S \S 240.14 a-1$ to $-13,101$ (1987).

124 Tax considerations will obviously influence the design of a merger transaction. The enactment of certain provisions in the Tax Reform Act of 1986, Pub. L. No. 99514,100 Stat. 2085 [hereinafter the 1986 Act], may make it more likely that the parties will desire to structure the transaction as a tax-free reorganization. See I.R.C. $\$ \S 354$, 361,368 (1982 \& West Supp. 1987). For example, $\S 631$ of the 1986 Act repeals the "General Utilities doctrine," I.R.C. §§ 336, 337 (1982) (providing, with exceptions, that no gains or losses will be recognized in a liquidation) and $\S 301$ of the 1986 Act repeals the preferential tax rates for long-term capital gains, I.R.C. $\S 1202$ (1982) (repealed 1986). See generally Maloney \& Brandt, Taxable and Nontaxable Acquisitive Techniques: A Case of the Basics Not Being Basic, 14 J. Corp. TAX'N 203 (1987) (The repeal of the preferential long-term capital gains rate and the General Utilities doctrine will make tax-free treatment of corporate acquisitions more appealing); Mullaney \& Bailine, Corporate Acquisitions After the Tax Reform Act of 1986, TAX ADVISER, Apr. 1987, at 212 (discussing the impact of the 1986 Act on corporate acquisitions and concluding that a greater emphasis will now be placed on tax-free reorganizations). Thus, an IRS ruling will be appropriate in many transactions that involve a large number of shareholders or a large amount of money or that are structured in a manner that deviates from the statutory or regulatory norm. See J. Freund, supra note 6 , at 92 ("[T]he more complicated the matter, the more it contains wrinkles that diverge from the statute, regulations and published rulings, . . . then the more appropriate it is to secure a ruling.").

${ }_{125}$ Under $\S 201$ of the Hart-Scott-Rodino Antitrust Improvements Act of 1976, 15 U.S.C. § 18a (1982 \& Supp. III 1985), and FTC Rules enacted thereunder, 16 C.F.R. $\S \S 800-03$ (1987), the prospective merger partners must file a premerger notification with the Federal Trade Commission and the Antitrust Division of the Department of Justice if the parties to the transaction and the assets or stock to be acquired in the transaction are above a certain size. The Hart-Scott-Rodino Act further provides that the proposed merger cannot close until the expiration of a minimum 30-day waiting period during which the Federal Trade Commission or the Justice Department may elect to challenge or attempt to enjoin the transaction. For a brief overview of this Act, see R. GiLson, supra note 106, at 1079-94.

${ }^{128}$ See, e.g., Cal. CoRP. CoDE $\S \S 1101,1101.1$ (West Supp. 1987), requiring 
tion; ${ }^{127}$ and obtain legal and accounting opinions. Performance of these covenants by the respective merger partners obviously is important to the ultimate success or failure of the merger. ${ }^{128}$

In marked contrast to these housekeeping covenants are provisions known as "exclusive merger covenants" that purport to offer the acquiring company some protection against actual or potential competing bidders. These exclusive merger provisions include: "best efforts" provisions; ${ }^{129}$ "no-shop" covenants; ${ }^{130}$ "stock or asset lock-

the state corporation commissioner or other official to approve the fairness of a transaction when prior to the merger the acquiring company owns between $50 \%$ and $90 \%$ of the target. In the absence of such approval or unanimous shareholder consent, the consideration provided target shareholders can consist only of common shares of the acquiring company.

${ }_{127}$ The merger negotiation process provides a means for the acquiring company to obtain nonpublic information about the target. Lawyers probably spend more time negotiating representations of the seller (target) than any other portion of the merger agreement. J. FREUND, supra note 6, at 229. These representations serve a disclosure purpose and can help to "smoke out" problem areas that may require further investigation. The accuracy of the target's representations is generally a condition precedent to the obligations of the acquiring company to close the merger. Therefore, such covenants provide an escape if the acquiring company discovers contrary information in its definitive investigation, which ordinarily takes place after the merger agreement is signed. See id. at 230-31.

${ }^{128}$ Successful performance of these covenants is also likely to be a condition to the parties' obligations to close the merger. See supra note 122.

${ }^{129}$ A typical "best efforts" provision was at issue in ConAgra, Inc. v. Cargill, Inc. 222 Neb. 136, 382 N.W.2d 576 (1986):

Best Efforts. The respective Boards of Directors and principal officers of each of ConAgra and MBPXL shall take all such further action as may be necessary or appropriate in order to effectuate the transactions contemplated hereby including recommending to their respective shareholders that the merger be approved; provided, however, nothing herein contained shall relieve either Board of Directors of their continuing duties to their respective shareholders.

222 Neb. at 146-47, 382 N.W.2d at 582. For a discussion of the effect of a competing fiduciary duty clause contained in a similar best efforts covenant, see Smith v. Van Gorkom, 488 A.2d 858, 879-80 (Del. 1985), and discussion, infra notes 168-87 and accompanying text.

130 "No-shop" covenants typically prohibit the target from actively seeking competing bids. Usually included within no-shop covenants are "no-negotiation" provisions, which prohibit the target from negotiating with potential competing bidders or from furnishing any nonpublic information to any third party seeking to acquire the target. See, e.g., Samjens Partners I v. Burlington Indus., Inc., 663 F. Supp. 614, 620, 625 (S.D.N.Y. 1987) (parties agreed to an explicit no-shop provision that prohibited the solicitation, but not the acceptance, of competing bids); Van Gorkom, 488 A.2d at 868, 878-80 (no-shop covenant part of original merger agreement). A "no-merger" covenant would prohibit the target from agreeing to merge with a third party pending the shareholder vote but would not restrain the target from negotiating with or providing information to competing bidders. Such a covenant could be implied from other standard merger terms limiting the target from selling assets or making contractual commitments other than in the ordinary course of business. See Merger Agreement Among Pay Less Drug Stores, Jewel Companies, Inc., and Jewel Acquisition Corp., Nov. 9, 1979, at $\S$ 9.2(iii), (v), (viii), cited in Jewel Cos. v. Pay Less Drug Stores Northwest, 
ups;"1s1 and "cancellation fees."132 The inclusion of these exclusive merger covenants in a merger agreement can have a significant impact on the structural and market monitors that police the target directors' decisions.

While Part II of this Article discussed loyalty issues, in this Part we assume that target directors have no conflict of interest. Instead, this Part focuses on the desirability of permitting even independent directors to enter into exclusive merger covenants. First, this Part analyzes whether corporate and contract principles permit directors to bind their corporation to any merger covenants without prior shareholder approval. Next, it analyzes judicial responses to exclusive merger covenants.

Inc., 741 F.2d 1555, 1565 (9th Cir. 1984). In Jewel Cos., the court remanded the case to the trial court for a determination of whether the parties intended these provisions to constitute an exclusive merger covenant. Id. at 1566-67, 1569. This Article will refer to no-shop, no-negotiation, and no-merger provisions as no-shop covenants.

131 A "lock-up" is an option given to a favored bidder to purchase important target assets or authorized target stock at an advantageous price. A lock-up option is generally exercisable if the merger fails to close due to shareholder rejection or, more commonly, if a competing bidder acquires a certain percentage of target shares. For examples of lock-ups, see Hanson Trust PLC v. ML SCM Acquisition, Inc., 781 F.2d 264, 266-67 (2d Cir. 1986) (offeror received an option to purchase two of the target's divisions in the event a third party acquired one-third or more of the target); Mobil Corp. v. Marathon Oil Co., 669 F.2d 366, 367 (6th Cir. 1981) (the offeror received an option to purchase ten million shares of the target's stock, equalling $17 \%$ of shares outstanding, as well as an option to purchase the target's $48 \%$ interest in an oil field in the event a third party gained control of the target); Thompson v. Enstar Corp., 509 A.2d 578, 583 (Del. Ch. 1984) (offeror received effective voting control of a joint partnership that was the most valuable asset of the target). Lock-ups involving stock options, while not ordinarily effective to thwart competitive bids, nevertheless provide cancellation fees to the disappointed suitor. See, e.g., Duffy, Lockups Designed to Promote Completion of the Acquisition, Nat'l L.J., Aug. 19, 1985, at 15, col. 3, 17, col. 2 (Baxter Travenol Laboratories, Inc. paid disappointed bidder HCA a sum approaching $\$ 200$ million to release its stock option lock-up). See generally infra note 132 (defining cancellation fees). For an example of a stock option lock-up that effectively guaranteed the offeror's success, see Data Probe Acquisition Corp. v. Datatab Inc., 722 F.2d 1, 3 (2d Cir. 1983) (target company granted option that allowed bidder to purchase voting shares equal to $200 \%$ of the target's then-outstanding shares), cert. denied, 465 U.S. 1052 (1984). New York Stock Exchange Rules forbid the granting of a stock option to acquire in excess of $18.5 \%$ of the outstanding common shares without shareholder approval. New York STOCK Exchange, supra note 7, § 312.00.

${ }_{132}$ A "cancellation fee," also known as a "break-up fee," "bust-up fee," "termination fee," or "penalty clause," is essentially a liquidated damages provision providing that the target will pay the bidder a specified sum in the event the merger fails to close. Events triggering cancellation fees include shareholder rejection of the merger, see, e.g., Friedman v. Baxter Travenol Laboratories, Inc., No. 8209, slip op. at 1 (Del. Ch. Feb. 18,1986 ) (merger agreement provided for $\$ 300$ million in liquidated damages if shareholders refused to approve merger), or acquisition attempts by competing bidders, see, e.g., DMG, Inc. v. Aegis Corp., No. 7619, slip op. at 3 (Del. Ch. June 29, 1984) (merger agreement provided for up to $\$ 1.25$ million for legal expenses plus an additional $\$ 1.5$ million if a competing bidder obtained more than $40 \%$ of target stock before a certain date). 


\section{B. The Legal Effect of Collateral Merger Covenants Prior to Shareholder Approval}

Under modern corporate statutes, mergers cannot take place without the approval of the target board ${ }^{133}$ and the target shareholders. ${ }^{134}$ Merger agreements, however, may contain many collateral covenants that purport to govern the conduct of the parties pending the shareholder vote. What the statutes do not expressly address is the legal status of such covenants in a board-approved merger agreement prior to the shareholder vote. ${ }^{135}$

The legal efficacy of collateral merger covenants turns on whether the necessary shareholder approval is a condition precedent to the formation of the merger contract itself or whether such approval is a condition precedent only to the duty to consummate the merger. ${ }^{136}$ Under the former view, no covenants in a board-negotiated agreement would be legally binding prior to shareholder consent. The latter view, however, would allow for a presently binding contract with enforceable covenants despite the lack of shareholder approval. Shareholder approval would constitute one of several conditions that must be fulfilled before the duty to merge arises.The first, and theoretically simplest issue, involves pure contract construction. A court must determine whether the

${ }^{133}$ See, e.g., Gal. CoRP. Code $\S \S 1001,1101,1200$ (West 1977 \& Supp. 1987); Del. Code ANN. tit. 8, $\S \S 251$ (b), 271 (a) (1983 \& Supp. 1986); N.Y. BuS. CoRP. LAw \$§ 902, 909 (McKinney 1986); MBCA, supra note 3, §§ 71-72A; RMBCA, supra note $3, \S \S 11.01-.02,12.02$.

134 See, e.g., Cal. Corp. Code $\$ \S 1001$ (a)(2), 1201 (West 1977 \& Supp. 1987); Del. Code ANN. tit. 8, $\S \S 251$ (c), 271(a) (1983 \& Supp. 1986); N.Y. BuS. CoRP. LAW §§ 903(a), 909(a) (McKinney 1986); MBCA, supra note 3, $\S \S 73,79$; RMBCA, supra note 3 , $\S \S 11.03,12.02$; see also supra note 7 .

185 The few cases addressing this issue have reached divergent results. Compare Jewel Cos. v. Pay Less Drug Stores Northwest, Inc., 741 F.2d 1555, 1560-64 (9th Cir. 1984) (two boards of directors may enter into an exclusive merger agreement) and Crouse-Hinds Co. v. InterNorth, Inc., 634 F.2d 690, 703-04 (2d Cir. 1980) (boardapproved exclusive merger agreement assumed valid) and Belden Corp. v. InterNorth, Inc., 90 Ill. App. 3d 547, 552-53, 413 N.E.2d 98, 102 (1980) (same) with ConAgra, Inc. v. Cargill, Inc., 222 Neb. 136, 156-58, 382 N.W.2d 576, 588 (1986) (board had no authority to bind corporation to merger agreement absent shareholder approval). See also Ward, supra note 16, at 788-99, 801-02 (noting the ambiguity inherent in the then-current statutes and calling for legislative reform). Ward suggests that the use of the term "plan" in the MBCA may signify a different meaning vis-à-vis contract formation than the term "agreement" as used in the Delaware statute. See id. at 793. We feel this is unlikely. See supra note 19.

${ }_{138}$ See, e.g., Mid-Continent Tel. Corp. v. Home Tel. Co., 319 F. Supp. 1176, 1190 (N.D. Miss. 1970) (stating, "[i]t is settled law that a condition precedent may be a condition which must be performed before the agreement of the parties shall become a binding contract or it may be a condition which must be fulfilled before the duty to perform an existing contract arises." (citing 17A C.J.S. Contracts $\S 338$ (1963); RESTATEMENT (SECOND) of Contracts § 250 (1979); 17 AM. JuR. 2D Contracts $\S 321$ (1964); 3A A. Corbin, Corbin on Contracts $\S 628(1960)$ ). 
language in the merger agreement indicates that the directors intended to enter into a presently binding contract. ${ }^{137}$ If the directors did not so intend, the inquiry ends, and, as a matter of basic contract law, no contract has been formed prior to shareholder approval. ${ }^{138}$ If, however, the directors intended the agreement as a present undertaking, ${ }^{139}$ then the issue remains whether they had the authority to bind their corporation to a given course of conduct prior to the shareholder vote. The relevant question is whether any principle of corporate law compels an interpretation of the merger agreement different from that mandated by traditional contract principles. ${ }^{140}$ The appropriate answer, which in-

${ }^{137}$ Intent is the keystone to the determination of whether the parties have not yet entered into a contract or have formed a present contract subject to a condition. See Restatement (SECOND) of ConTracts, supra note $136, \S \S 224-230$. Intent can be ascertained not only from the terms of the agreement itself but also from the words and deeds of the parties. See Winston v. Mediafare Entertainment Corp., 777 F.2d 78, 8083 (2d Cir. 1985); Reprosystem, B.V. v. SCM Corp., 727 F.2d 257, 261-63 (2d Gir.), cert. denied, 469 U.S. 828 (1984); Texaco, Inc. v. Pennzoil, Co., 729 S.W.2d 768, 78896 (Tex. Ct. App. 1987). If a conditional contract is "capable of two constructions, the court must choose that interpretation which will make the contract legally binding if it can be so construed without violating the intention of the parties." Bleecher v. Conte, 29 Cal. 3d 345, 350, 698 P.2d 1154, 1157, 213 Cal. Rptr. 852, 855 (1981); see also General Motors Acceptance Corp. v. Berg \& Duffy, 118 Misc. 2d 525, 527-28, 460 N.Y.S.2d 899, 901 (Sup. Ct. 1983) (stating the general principle that "contract provisions are not to be construed out of context and in isolation . . . and that an interpretation which will leave a provision without force and effect is to be avoided").

${ }^{138}$ See, e.g., Los Angeles Rams Football Club v. Cannon, 185 F. Supp. 717, 72122 (S.D. Cal. 1960) (the terms of the document clearly indicate that the approval of a third party was essential to the formation of the contract); see also Transcontinental Gas Pipe Line Corp. v. Federal Energy Regulatory Comm'n, 659 F.2d 1228, 1233 (D.C. Cir. 1981) (a settlement agreement between the parties erected a condition precedent that the Cost of Living Council approve the agreement).

139 It is most likely that corporate directors as parties to a formally-executed merger agreement intend that the agreement constitutes a present undertaking and the language will, or at least should, be drafted accordingly. Even an agreement in principle subject to the execution of a formal agreement should clearly state whether the parties intend it to constitute a binding agreement. See J. FREUND, supra note 6, at 61 ("There should be no ambiguity about this point; either it's a contract or it's not."). For an extreme example of the dire consequences which can result from ambiguity regarding the binding effect of an agreement in principle, see Texaco, 729 S.W.2d at 865-66 (Texaco held liable for $\$ 8.53$ billion in damages for tortious interference with the Pennzoil/Getty merger contract). See generally Temkin, When Does the "Fat Lady" Sing? An Analysis of "Agreements in Principle" in Corporate Acquisitions, 55 FordHAM L. REv. 125 (1986) (discussing the contract issues arising from "agreements in principle").

140 See Jewel Cos. v. Pay Less Drug Stores Northwest, Inc., 741 F.2d 1555, 1564 (9th Cir. 1984) (stating that its decision upholding an exclusive merger agreement was merely in accord with the contract doctrine that the pursuit of competitive advantage is insufficient to void an otherwise valid contract). The Jewel Cos. court's reasoning is criticized as circular in Buxbaum, supra note 24, at 1703. Professor Buxbaum, however, appears to be concerned more with the exclusive nature of the Jewel merger agreement rather than our present inquiry concerning the board's authority to enter into any binding covenants prior to shareholder approval. The additional problems 
volves the integration of corporate law and the common law of contracts, is not, however, readily apparent from the state corporate statutes.

Current corporate statutes provide that the business affairs of a corporation are managed by or under a board of directors. ${ }^{141}$ With specific reference to mergers, the statutes provide that two corporations can merge only if the board of directors of each corporation approves a merger agreement. ${ }^{142}$ At least a majority of the outstanding shares of the target company must then approve the merger agreement or its principal terms. ${ }^{143}$ Under some statutes, the respective corporate boards can thereafter amend a merger agreement, without further shareholder approval, so long as the amendments do not affect the basic merger terms. ${ }^{144}$ Finally, a board generally can abandon a merger, subject to the contractual rights of third parties, even after the merger has been approved by the shareholders. ${ }^{145}$ The current statutes do not, however,

presented by exclusive merger covenants are discussed infra notes 168-223 and accompanying text.

11 See, e.g., Cal. Corp. Code $\S 300$ (West 1977 \& Supp. 1987); Del. Code ANN. tit. 8, §141 (1983 \& Supp. 1986); N.Y. Bus. CoRP. LAw $\S 701$ (McKinney 1986); MBCA, supra note 3, § 35; RMBCA, supra note 3, § 8.01(b).

${ }_{142}$ See, e.g., Cal. Corp. Code $\S 1200$ (West 1977); Del. Code AnN. tit. 8, $\S 251(b)$ (1983); N.Y. Bus. CoRP. LAw $\S 902$ (McKinney 1986); MBCA, supra note 3, §§ 71-72A; RMBCA, supra note 3, §§ 11.01-.02.

${ }_{143}$ While most statutes arguably require shareholder approval of the entire merger agreement, see, e.g., DEL. CODE ANN. tit. 8, § 251(c) (1983); N.Y. Bus. CoRP. LAw § 903 (McKinney 1986); MBCA, supra note 3, § 73(b), under the California Code, the shareholders need only approve principal merger terms, see Cal. Corp. CODE $\S 1201$ (West 1977 \& Supp. 1987). The RMBCA implicitly adopts the California model in that it provides that the merger plan requiring shareholder approval need only contain the basic terms of the merger and any changes in the charter of the acquiring company. See RMBCA, supra note 3, \$11.01. Moreover, the courts have not literally interpreted statutes that on their face require shareholder approval of the entire merger agreement. See, e.g., Buffalo Forge Co. v. Ogden, 555 F. Supp. 892, 905 (W.D.N.Y.) (only the "plan of merger," not the entire acquisition agreement, requires shareholder approval), affd, 717 F.2d 757 (2d Cir.), cert. denied, 464 U.S. 1018 (1983).

144 See, e.g., Cal. Corp. Code $\$ 1104$ (West 1977 \& Supp. 1987).

14s See, e.g., Cal. CoRP. CODE $\S \S 1001(\mathrm{~b}), 1201$ (f) (West 1977 \& Supp. 1987); Del. Code ANN. tit. 8, $\S \S 251$ (d), 271(b) (1983) (phrased as "termination"); N.Y. Bus. CoRP. LAw $\S \S 903(\mathrm{~b}), 909(\mathrm{f})$ (McKinney 1986); MBCA, supra note 3, $\S \S 73(\mathrm{c}), 78(\mathrm{~d}) ; \mathrm{RMBCA}$, supra note $3, \S \S 11.03(\mathrm{i}), 12.02(\mathrm{f})$. These abandonment provisions have been construed as both supporting and contradicting directors' authority to enter into a binding merger contract prior to the shareholder vote. Compare Jewel Cos. v. Pay Less Drug Stores Northwest, Inc., 741 F.2d 1555, 1563 n.10 (9th Cir. 1984) (abandonment provision supports broad legality of exclusive merger agreement because it recognizes that the acquiring company has significant rights prior to the shareholder vote) with Buxbaum, supra note 24, at 1703 (necessary implication of abandonment provision that is operative after the shareholder vote is that no binding contract exists prior to the shareholder vote). It is most likely, however, that the abandonment provisions do not address this issue one way or another. Instead, these provi- 
directly address the issue of the validity of collateral covenants in the board-approved merger agreement pending the shareholder vote. The question of the directors' powers to enter into binding merger covenants must therefore be extrapolated from the general statutory language.

The narrowest interpretation of the statutory merger provisions is represented by the "offer/shareholder acceptance" theory of corporate contract formation. This approach suggests that shareholder acceptance of a merger agreement is a statutory precondition to the validity of the collateral covenants contained therein. The Supreme Court of $\mathrm{Ne}$ braska, applying Delaware law, recently adopted this theory of contract formation. In ConAgra, Inc. v. Cargill, Inc. ${ }^{146}$ an unsuccessful bidder sued the target and the successful competing bidder to recover damages for breach of contract and tortious interference with contract. In reversing a summary judgment for the plaintiff, the Nebraska court stated that prior to shareholder approval a merger agreement between two corporate boards created no enforceable rights between the parties. ${ }^{147}$ In reaching this conclusion, however, the court relied upon cases of dubious relevance. ${ }^{148}$ Furthermore, the doctrinal basis underlying the

sions simply relieve directors of their obligation to seek further shareholder consent to abandon an agreement already endorsed by the shareholders. There is no need for a provision allowing abandonment prior to the shareholder vote because the directors could, as a matter of course, abandon such an agreement subject to whatever contractual rights may exist in third parties. The provisions do not address whether contract rights in the acquiring company do or do not exist prior to the shareholder vote. The matter of abandonment is therefore solely between directors and shareholders and does nothing to diminish or enlarge the rights of third parties such as the acquiring company. See Ward, supra note 16, at 791-92.

${ }_{148} 222$ Neb. 136, 382 N.W.2d 576 (1986).

147 Id. at 156, 382 N.W.2d at 588 ("The MBPXL board was without statutory power to bind the corporation to the proposed ConAgra merger absent shareholder approval.").

${ }^{148}$ In support of its conclusion that shareholder approval is a necessary prerequisite to the formation of a merger contract the Nebraska court relied upon Smith v. Good Music Station, 36 Del. Ch. 262, 129 A.2d 242 (1957); Masonic Temple, Inc. v. Ebert, 199 S.C. 5, 18 S.E.2d 584 (1942); and Finklea v. Carolina Farms Co., 196 S.C. 466, 13 S.E.2d 596 (1941); ConAgra, 222 Neb. at 156-57, 382 N.W.2d at 588. In both Finklea and Masonic Temple, the courts found that officers of the defendant corporation could not bind their corporation to sell substantially all of its assets without the necessary shareholders' approval as required by the statute. Both cases can be readily distinguished from the ConAgra facts in that they included an alleged agreement by corporate officers, not a board of directors; a statute ( $\$ 7705$ of the S.C. CODE (1932)) that provided no role for a board of directors but only for the shareholders; and a dispute over the consummation of the actual sale rather than enforcement of a collateral covenant in the agreement. In Smith, the Delaware court, confronted with a two-offer situation, avoided the issue concerning the legal effect of a sale-of-assets contract prior to shareholder approval. Again, the issue in Smith involved the ultimate sale of the assets rather than collateral covenants in the agreement. The legal effect of a preliminary sales agreement approved by defendant's directors and shareholders was addressed in American Cyanamid Co. v. Elizabeth Arden Sales Corp., 331 F. Supp. 597 
ConAgra decision is somewhat murky given that the court also based its decision upon its interpretation of the specific language of the merger agreement ${ }^{149}$ as well as its analysis of the target board's fiduciary duty to its shareholders. ${ }^{150}$ Either of the latter rationales could have independently justified the court's decision; hence, its support for the offer/shareholder acceptance theory is of questionable precedential value. Most courts have at least implicitly rejected the offer/shareholder acceptance theory of corporate contract formation. Instead, they have found that the directors' broad powers to run the business affairs of the corporation, when coupled with their statutory role in mergers, validates the directors' unilateral power to bind the corporation to almost any agreement short of the merger itself. For example, in Belden Corp. v. Internorth, Inc., ${ }^{161}$ the Illinois Appellate Court stated that pending the shareholder vote, the initial bidder had a valid contract with the target that gave it an "enforceable expectation with regard to the performance of [target] management."152 In a related case arising from the same acquisition battle, the Second Circuit Court of Appeals similarly noted that target directors were contractually bound to the initial bidder. ${ }^{253}$ Other courts considering merger agreements have implicitly assumed that target directors could enter into a binding contract

(S.D.N.Y. 1971), also cited in ConAgra, 222 Neb. at 157, 382 N.W.2d at 588. This case is thus irrelevant to the issue at hand.

${ }^{149}$ ConAgra, 222 Neb. at 155, 382 N.W.2d at 587 ("continuing duties" clause in best efforts provision of the merger agreement contemplated directors' duty to present higher offers to shareholders). See Kalish, ConAgra, Inc. v. Cargill, Inc. An Interpretive Essay: A Target Corporation May, but Need Not, Agree That Its Directors Serve as Auctioneers for Its Shareholders, 65 NEB. L. REv. 823, 824 (1986) (suggesting that the ConAgra opinion, "properly understood, merely interpreted the 'best-efforts' clause in the ... merger agreement").

1so See ConAgra, 222 Neb. at 156, 382 N.W.2d at 588 (directors' actions in advising shareholders of higher offer and recommending approval of that offer was consistent with their fiduciary duties and did not constitute a breach of contract); see also infra notes 168-87 and accompanying text. There is a confusing aside in the ConAgra majority opinion suggesting that the target directors may be individually liable for breaching an enforceable agreement between themselves and the ConAgra board. ConAgra, at 156, 382 N.W.2d at 587. While the basis for this suggestion is not reported, in the absence of loyalty issues it appears a curious distortion of the business judgment rule. See supra notes 25-29 and accompanying text (discussing the business judgment rule). But see Kalish, supra note 149, at $826 \mathrm{n.11}$ (suggesting that individual liability could attach to certain directors who solicited higher bids in breach of the merger agreement). For further discussions of the ConAgra decision, see generally Santoni, The Integration of Contract, Corporate, and Tort Law Principles: ConAgra, Inc. v. Cargill, Inc., 20 CREIGHTON L. REv. 317 (1987); Note, "What's a Handshake Worth?" ConAgra, Inc. v. Cargill, Inc., 20 CREIGHTON L. Rev. 493 (1987).

18190 Ill. App. 3d 547, 413 N.E.2d 98 (1980).

$182 I d$. at 553, 413 N.E.2d at 102.

${ }^{153}$ Crouse-Hinds Co. v. Internorth Inc., 634 F.2d 690, 703 n.22 (2d Cir. 1980). 
with the acquiring company prior to the vote of target shareholders. ${ }^{154}$

In Jewel Cos. v. Pay Less Drug Stores Northwest, Inc. ${ }^{155}$ the Ninth Circuit Court of Appeals expressly rejected the offer/shareholder acceptance theory of corporate contract formation. In Jewel Cos., the boards of directors of Jewel Companies and Pay Less Drug Stores entered into a written merger agreement. After the agreement was publicly announced, but prior to a vote by the Pay Less shareholders, the defendant, Pay Less Northwest (Northwest), ${ }^{106}$ purchased $12 \%$ of Pay Less stock and announced a cash tender offer for the remaining shares. The Northwest and Pay Less boards subsequently entered into a merger and related indemnity agreement providing for the merger of Northwest and Pay Less after the completion of the Northwest tender offer. ${ }^{157}$ The Pay Less Board then recommended to its shareholders that they reject the Jewel merger proposal and accept the Northwest tender offer. Northwest became the majority Pay Less shareholder through its tender offer and thereafter passed a shareholders' resolution rejecting the Jewel merger. Jewel sued Northwest for tortious interference with its merger contract. ${ }^{158}$

154 See, e.g., R-G Denver Ltd. v. First Gity Holdings of Colorado, Inc., 789 F.2d $1469,1473-74$ (10th Cir. 1986) (binding contract assumed, but no collateral covenants were violated); Great Western Producers Coop. v. Great Western United Corp., 200 Colo. 180, 186, 613 P.2d 873, 878 (1980) ("In the absence of [contrary evidence] it will be presumed that the parties to a contract intended to form a lawful and enforceable agreement.'); Smith v. Van Gorkom, 488 A.2d 858, 878-80, 888 (Del. 1985) (assuming that target board members entered into a binding merger contract prior to shareholder approval of the merger agreement). See also Texaco, Inc. v. Pennzoil Co., 729 S.W.2d 768, 791 (Tex. Ct. App. 1987) ("agreement in principle" constituted enforceable contract that precluded target directors from accepting a higher offer).

188741 F.2d 1555 (9th Cir. 1984).

158 Although they had similar corporate names resulting from a common ancestor, Pay Less and Pay Less Northwest were entirely unrelated corporations prior to the events in the Jewel Cos. litigation. Id. at 1557 n.1.

${ }_{157}$ Except for the price, the Northwest/Pay Less merger agreement was identical to the Jewel/Pay Less merger agreement. Appellant's Opening Brief at 8-9, Jewel Cos., 741 F.2d 1555 (No. 82-4382). The Northwest/Pay Less Indemnity and Record Date Agreement provided that Northwest would indemnify Pay Less and its directors for any alleged breach of the Jewel agreement and it committed the Pay Less Board to abandon the Jewel merger if it were approved by Pay Less shareholders (a theoretical possibility due to the mechanics of transferring record ownership of shares). See Jewel Cos., 741 F.2d at 1558. As part of the overall agreement, Northwest increased its tender offer price by $\$ 1.50$ per share. Id.

${ }^{158}$ The tort of contract interference has been increasingly used by disappointed bidders against their successful counterparts, sometimes with incredible results. See, e.g., Texaco, Inc. v. Pennzoil Co., 729 S.W.2d 768, 866 (Tex. Ct. App. 1987) (\$7.53 billion in general damages plus $\$ 1$ billion in punitive damages). The Restatement defines the contract interference tort as follows:

One who intentionally and improperly interferes with the performance of a contract (except a contract to marry) between another and a third person by inducing or otherwise causing the third person not to perform the con- 
Before the trial court, Northwest successfully argued that prior to shareholder approval, two corporate boards cannot enter into binding merger covenants. ${ }^{189}$ The Ninth Gircuit Court of Appeals reversed, holding that the California Corporations Code contemplates that the boards of two companies seeking to merge can enter into a binding agreement governing the conduct of the parties pending the shareholder vote. The court thus clearly rejected the offer/shareholder acceptance theory of contract formation. In reaching this decision, the court relied upon the directors' statutory authority to manage the business affairs of the corporation. The court stated that while a board's actions concerning mergers and other control transactions might be subject to special judicial scrutiny, "there is nothing so unique about a negotiated merger

tract, is subject to liability to the other for the pecuniary loss resulting from the failure of the third person to perform the contract.

Restatement (SECOND) OF ToRTs $\$ 766$ (1977). For cases involving this tort in the corporate acquisition setting, see generally Jewel Cos., 741 F.2d 1555; American Cyanamid Co. v. Elizabeth Arden Sales Corp., 331 F. Supp. 597 (S.D.N.Y. 1971); Pennzoil Co. v. Getty Oil Co., slip op., No. 7425 (Del. Ch. Feb. 6, 1984); Belden, 90 Ill. App. 3d 547, 413 N.E.2d 98; ConAgra, 222 Neb. 136, 382 N.W.2d 576; Texaco, 729 S.W.2d 768. See also Dobbs, Tortious Interference With Contractual Relations, 34 ARK. L. REv. 335, 337 (1980) (arguing that there is "no sound basis for any universal rule of liability" for the interference with contract tort); Perlman, Interference with Contract and Other Economic Expectancies: A Clash of Tort and Contract Doctrine, 49 U. CHI. L. REv. 61 (1982) (examining and suggesting an unlawful means test to limit the interference tort when it is used to redress economic loss); Comment, $A n$ Analysis of the Formation of Property Right Underlying Tortious Interference with Contracts and Other Economic Relations, 50 U. CHI. L. REv. 1116, 1118-26 (1983) (analyzing scholarship critical of the interference tort and presenting a theoretical justification for interference liability).

The relatively new tort of interference with prospective commercial advantage could be applicable to an acquisition setting if no contract yet existed between the plaintiff acquiring company and the target. The tort of interference with prospective commercial advantage applies if a defendant intentionally and improperly causes the target not to enter into a prospective contractual relationship with the plaintiff. There are several defenses or justifications for such interference, however, including fair economic competition and the protection of one's own financial interests. See ResTATEMENT (SECOND) OF TORTS, supra, $\S \S 766(b), 767,768$. A key element making this tort unavailable in most acquisition battles is the necessity of illegal or wrongful conduct by the defendant. Competition for the target, while not a defense to a contract interference claim, does constitute a defense to an interference with prospective advantage cause of action. See Belden, 90 Ill. App. 3d at 552-54, 413 N.E.2d at 101-03. While the plaintiff in Jewel Cos. relied upon the interference with prospective commercial advantage tort as an alternative basis for recovery, this tort was not analyzed by either the trial court or the Ninth Circuit Court of Appeals. See Jewel Cos., 741 F.2d at 1559 n.3; see generally Lowenstein, Tender Offer Litigation and State Law, 63 N.C.L. REv. 493 (1985) (discussing difficulties involved in maintaining an action for interference with prospective commercial advantage in the takeover context); Comment, Interference with a Prospective Business Relationship: An Old Tort for the New Marketplace, 35 BAYLOR L. REv. 123 (1983) (analyzing tort of interference with prospective business relationship and comparing it to other business torts).

${ }^{168}$ See Jewel Cos., 550 F. Supp. 770, 772 (N.D. Cal. 1982). 
transaction as to warrant the extraordinary step of sterilizing the directors in favor of direct and exclusive action by the shareholders."160 The court thus placed negotiated merger transactions in the category of ordinary business decisions that are routinely entrusted to the directors. Carried to its logical conclusion, this reasoning suggests that collateral covenants in merger agreements are valid prior to the shareholder vote.

The Jewel Cos. court, however, did not have to base its holding solely upon the directors' general powers to run the business affairs of a corporation. Under California's statutory scheme, the shareholders need only approve principal merger terms. ${ }^{161}$ Other covenants in merger agreements that govern the conduct of the parties pending the shareholder vote are left within the province of the respective corporate boards. The court found that this dichotomy in the statute necessarily defeated the argument that contract formation was dependent upon shareholder consent. Therefore, the court held that, far from mandating the abrogation of an otherwise enforceable contract, the California Code authorizes binding board-negotiated merger covenants. ${ }^{\mathbf{1 0 2}}$

There is a third approach to interpreting the current statutes that neither scholars nor the courts have adequately addressed. This approach suggests segregating merger covenants into those pertaining to ordinary business transactions and those that fundamentally alter the structure of the corporation. The former type of covenants, primarily

${ }^{180}$ Jewel Cos., 741 F.2d at 1560. But see Gilson I, supra note 13, at $848 \mathrm{n} .106$ (arguing that merger transactions are unique because they are statutorily preconditioned upon shareholder approval while analogous policy decisions by the directors are not).

181 Section 1201(a) of the California Corporations Code provides that shareholders must approve "[t]he principal terms of a reorganization," and further provides that a "reorganization" includes a negotiated merger. CAL. CORP. CODE $\S \S 1200$ (a), 1201(a) (West 1977 \& Supp. 1987). The California statute does not, however, define the phrase "principal terms." Nevertheless, there appears to be a common understanding in California that "principal terms" means only the offering price, exchange ratios, and other bare-bones terms of the merger itself. This definition comports with the requirements of the California Secretary of State with whom the principal merger terms must be filed, Cal. Corp. Code $\S 1103$ (West 1977 \& Supp. 1987).

${ }_{182}$ Jewel Cos., 741 F.2d at 1561 . This statement by the court in Jewel Cos. should not be interpreted to mean that the California Legislature addressed this issue; it did not. The California Corporations Code was completely revised in 1975. The two basic objectives of the revisions of the merger provisions were (1) to treat all corporate combinations in the same manner so far as the requirement for shareholders' voting and appraisal rights were concerned, and (2) to permit voting and appraisal rights only when a transaction significantly changed the rights or diluted the voting power of corporate shareholders. CAL. CoRP. CoDE $\S \S 1200,1201$ Legislative Committee Comment (West 1977); see also Small, Corporate Combinations Under the New California General Corporation Law, 23 UCLA L. REv. 1190, 1190-91 (1976). The legislative history does not indicate that the California Assembly ever considered the effect of the statutory changes upon the legal efficacy of board-approved merger covenants prior to the shareholder vote. 
the routine housekeeping provisions, closely resembles activities that are ordinarily entrusted to a board of directors. ${ }^{163}$ Statutory provisions providing that directors govern the business affairs of a corporation, when coupled with the directors' statutory role in the merger process, empower the board to make binding commitments in these areas. On the other hand, certain exclusive merger covenants, such as lock-ups and cancellation fees, can significantly change the nature of the shareholders' investment or effectively predetermine the outcome of the shareholder vote. Such provisions, along with the basic terms of the merger itself, are beyond the scope of ordinary business affairs entrusted to corporate directors. As a result, these covenants could not, under a fair reading of the statutes, constitute binding corporate commitments prior to the shareholder vote.

While arguments exist to support each of these three approaches to interpreting the corporate statutes, no clear legal principles presently mandate the adoption of any one of them. Part of the analysis depends on whether one perceives directors as having only the powers enumerated in the statutes or whether they have all powers unless otherwise provided in the statutes. ${ }^{104}$ Some cases espousing the offer/shareholder acceptance have adopted the first approach, ${ }^{165}$ while other cases, often involving tender offers, adopt the second approach. ${ }^{168} \mathrm{We}$ are predisposed towards the third approach that makes the directors' authority dependent upon the nature of the disputed merger covenant. Directors should be able to exercise all powers that do not unduly interfere with either the structural role assigned to shareholders or the market that provides alternative choices. ${ }^{167}$ While one can massage general statutory language to achieve a specified result, the essential point is that such statutory ambiguity is completely unnecessary. The issue, having been

${ }^{163}$ For example, the preparation of proxy solicitation materials or SEC registration statements is an undertaking ordinarily entrusted to the directors and their legal and financial advisors without shareholder input.

164 The answer to this question depends to a large degree upon one's view of the corporate enabling statutes. Professor Cary, for example, described "Enabling Acts" as those "enabling management to operate with minimum interference." Cary, Federalism and Corporate Law: Reflections Upon Delaware, 83 YALE L.J. 663, 666 (1974).

${ }_{165}$ See, e.g., ConAgra, 222 Neb. 136, 156, 382 N.W.2d 576, 588 (Where applicable law required the board to submit to the shareholders its resolution approving a merger, the board could not then bind the corporation to the merger absent shareholder approval.).

${ }^{188}$ See, e.g., Unocal Corp. v. Mesa Petroleum Co., 493 A.2d 946, 957 (Del. 1985) ("Merely because the General Corporation Law is silent as to a specific matter does not mean that it is prohibited.").

${ }^{167}$ While we feel that this is a reasonable interpretation of current statutes, in Part IV we propose a rule that explicitly makes a distinction between routine merger covenants and essential merger terms including lock-ups and cancellation fees. 
raised in recent cases with divergent results, needs clarification. A more reasoned corporate statute should contain definitive standards to address the problem.

\section{G. Exclusive Merger Covenants}

The previous section addressed the directors' statutory authority to enter into binding merger covenants prior to the shareholder vote. That issue is primarily a question of the proper integration of contract law and the corporate statutes. The inclusion of exclusive merger covenants in merger agreements presents additional concerns apart from the directors' contractual authority. We have divided these provisions into two categories, each requiring separate analysis: (1) promises regarding board performance; and (2) lock-ups or cancellation fees. The first category includes best efforts and no-shop covenants in which the target directors promise the acquiring company that they will engage in a certain course of conduct pending the shareholder vote. Lock-ups and cancellation fees, on the other hand, represent promises by target directors, upon the occurrence of a triggering event, to transfer to the acquiring company stock or assets of the target corporation.

\section{Performance Promises}

Perhaps the most common board performance promises are best efforts covenants that ordinarily require the target directors to take all actions necessary to effectuate the merger, including recommending approval to target shareholders. Beyond these promises, the acquiring company, via no-shop covenants, may seek to prevent the target directors from seeking or negotiating with competing bidders.

The major problem concerning performance promises arises when a competing bidder enters the fray. ${ }^{168}$ The potential for, or presence of, a competing bid can place the target board in a legal quagmire between its contractual commitments to the initial bidder and its competing fiduciary obligations to secure the best deal for its shareholders. A target board that accepts a competing bid in the face of a rule validating exclusive merger promises could subject the target to liability to the initial bidder for breach of contract. Similarly, the competing bidder could be liable to the initial bidder for tortious interference with contract. ${ }^{169} \mathrm{~A}$

168 The decision of the Delaware Supreme Court in Smith v. Van Gorkom, 488 A.2d 858, 858 (Del. 1985), represents one of the few cases in which the court has analyzed the impact of performance promises in the context of a merger transaction not involving competitive bidders.

${ }_{160}$ See supra note 158. 
contrary rule, on the other hand, allowing a fiduciary duty "escape" from exclusive merger promises, would necessarily increase the transaction costs for the initial bidder. ${ }^{170}$

At present, there is scant legal authority addressing this issue. The unsettled legal rules make it difficult for target directors, as well as for the initial and competing bidders, to evaluate accurately the risks inherent in their respective positions. The few judicial opinions addressing this question espouse differing views concerning its proper resolution. There is little question that even in the face of exclusive merger promises, a competing bidder can pursue a tender offer to target shareholders without subjecting itself to tort liability. ${ }^{171}$ Furthermore, SEC rules, ${ }^{172}$ as well as fiduciary duty principles, ${ }^{173}$ require the target directors to disclose to target shareholders information regarding a compet-

170 An acquiring company predicates its offering price upon (1) the value of the target, and (2) risks involved in attempting the acquisition. An enforceable no-shop clause eliminates one risk-that a competing bidder can negotiate a merger agreement with the target. See Easterbrook \& Jarrell, Do Targets Gain from Defeating Tender Offers?, 59 N.Y.U. L. REv. 277, 283 (1984) (prices paid by suitors for target stock are $8 \%-20 \%$ higher in auction setting than at time of initial offer).

171 This seems self-evident from the fact that in pursuing a tender offer, a competing bidder does not request the target to break its contract, an essential element of the tort of contract interference. For example, in Belden, the plaintiff's contention that the defendant's tender offer to target shareholders constituted tortious interference with the merger contract between the plaintiff and the directors failed because the contract did not entitle plaintiff to the benefits of the merger, which was subject to shareholder approval, but only to the specified performance of the target's management: presenting and recommending the merger to the target shareholders. See Belden, 90 Ill. App. 3d at 552-53, 413 N.E.2d at 102. While this question was not before the court in Jewel Cos., the point was conceded by the plaintiffs, see Appellant's Reply Brief at 8 , Jewel Cos., 741 F.2d 1555 (No. 82-4382) ("Northwest could simply have tendered directly for the Pay Less shares . . . without inducing breach of contract"), and implicitly endorsed by the court, Jewel Cos., 741 F.2d at 1564 (Although "the board can bind itself to exert its best efforts to consummate the merger," it is bound only temporarily, pending approval by the shareholders, who "remain free . . . to respond to a merger proposed or tender offer made. . . subsequent to the board's execution of exclusive merger agreement . . . ").

172 See, e.g., SEC Rule 14a-9(a), 17 C.F.R. § 240.14a-9(a) (1987) (requiring that proxy solicitations contain accurate information when made and further requiring correction of earlier statements which may have become false or misleading); see also Gerstle v. Gamble-Skogmo, Inc., 478 F.2d 1281, 1294-98 (2d Cir. 1973) (proxy statement was materially misleading because it failed to disclose intention of acquiring company to liquidate target assets).

${ }^{173}$ Fiduciary duty principles require directors to disclose to their shareholders all facts germane to the transaction at hand. See, e.g., Smith v. Van Gorkom, 488 A.2d 858,890 (Del. 1985) ("[C]orporate directors owe to their stockholders a fiduciary duty to disclose all facts germane to the transaction at issue in an atmosphere of complete candor." (citing Lynch v. Vickers Energy Corp., 383 A.2d. 278, 279 (Del. 1978))). Certainly, the existence of a competing offer is germane to any merger transaction. See Jewel Cos., 741 F.2d at 1564 ("[A] board may not, consistent with its fiduciary obligations, withhold [from shareholders] information regarding a potentially more attractive competing offer."). 
ing offer. Beyond these guidelines, the rights of the suitors and the responsibilities of the target directors remain unclear.

With regard to contractual best efforts covenants, one line of cases holds that target directors must implement such provisions consistently with fulfilling their fiduciary duties. Under this reasoning, target directors could not, consistent with their fiduciary duties, recommend the original proposal in the face of changed circumstances, such as a more attractive offer. In this situation, the target directors' failure to fulfill the best efforts covenant would not result in contractual liability. The seminal case to espouse this viewpoint was Great Western Producers Co-operative v. Great Western United Corp. ${ }^{174}$ In Great Western, the defendant's board of directors agreed to sell to the plaintiff the outstanding stock of its wholly-owned sugar-producing subsidiary. The board specifically agreed as a precondition of the sale to use its best efforts to obtain shareholder approval. ${ }^{175}$ After learning of increases in actual and projected sugar prices, the defendant's board withdrew its original recommendation that the shareholders approve the sale. The Supreme Court of Colorado, applying Delaware law, held that the defendant directors had a fiduciary duty to their shareholders to exercise independent judgment and inform them of the changed circumstances that had convinced the directors that the contract was no longer desirable. ${ }^{278}$ Therefore, the court found that defendants did not breach the sales agreement because the best efforts clause had to be implemented in a manner consistent with the board's fiduciary duties. ${ }^{177}$

The Tenth Circuit Court of Appeals, in a recent case brought by an initial bidder against a competing bidder for tortious interference with contract, agreed with the Great Western analysis. In $R-G$ Denver, Ltd. v. First City Holdings, ${ }^{178}$ the court, citing Great Western, held that the defendant board had a fiduciary duty, under Colorado law, to inform its shareholders of a competing bid and to make its recommendations accordingly. ${ }^{179}$ The court found that the board's recommendation of the competing bid, in the face of a best efforts promise to the initial bidder, did not constitute a breach of contract. ${ }^{180}$

174200 Colo. 180, 613 P.2d 873 (1980).

178 This sale required the approval of Great Western shareholders because the stock of the subsidiary was Great Western's major asset. See Del. CodE ANN. tit. 8, $\S 271$ (a) (1983 \& Supp. 1986).

${ }^{178}$ See Great Western, 200 Colo. at 186-87, 613 P.2d at 878-79.

177 See id.

178789 F.2d 1469 (10th Cir. 1986).

179 See id. at 1474-75. The court reached the same result due to the language of the merger agreement, $i d$. at 1474, and proxy provisions of the federal securities laws, id. at 1475 .

${ }^{180}$ Id. at 1475; see also ConAgra, 222 Neb. at 155, 382 N.W.2d at 587 (directors 
A contrary view appears in two judicial opinions resulting from a dispute over control of the Crouse-Hinds Company. ${ }^{181}$ Belden Corporation agreed to merge into a wholly-owned Crouse-Hinds subsidiary through an exchange of stock, a transaction that required the approval of the shareholders of both Belden and Crouse-Hinds. Internorth then made a tender offer directly to the Crouse-Hinds shareholders, conditioned on the termination or rejection of the Belden merger agreement. Belden, fearing that the Internorth tender offer would defeat its merger plans, sued Internorth, claiming that the tender offer constituted tortious interference with the merger contract that had been approved by the boards of Belden and Crouse-Hinds. In rejecting this claim, the Illinois Appellate Court stated:

This contract gives Belden an unequivocal right to receive the performance of Crouse's management, i.e., Belden is entitled to have the merger presented and recommended to Crouse's shareholders. Belden and its shareholders do not, however, have an unequivocal right to the benefits of the merger, since the power to approve the merger lies with the Crouse shareholders, and the contract imposes no duty on the shareholders to ratify the merger agreement. Belden, therefore has an enforceable expectation with regard to the performance of Crouse's management, but has a mere expectancy with respect to consummation of the merger. ${ }^{182}$

The emphasized language, while dicta, strongly suggests that a target board would be contractually bound to recommend approval of a merger even if a better offer materialized. Similarly, in a case arising out of the same transaction, the Second Circuit Court of Appeals upheld a premerger share exchange between Belden and Crouse-Hinds, stating that "[w]e know of no support for the district court's view that the Grouse-Hinds directors were required to 'reconsider' the merger agreement that had been entered into and that they were contractually bound to recommend to shareholders."

cannot contract away duty to use their best judgment or to advise shareholders of better offers).

${ }_{181}$ See Crouse-Hinds Co. v. Internorth, Inc., 634 F.2d 690 (2d Cir. 1980); Belden, 90 Ill. App. 3d 547, 413 N.E.2d 98.

${ }_{182}$ Belden, 90 Ill. App. 3d at 552-53, 413 N.E.2d at 102 (emphasis changed).

${ }^{183}$ Crouse-Hinds, 634 F.2d at 703 n.22 (citation omitted); see also Smith v. Van Gorkom, 488 A.2d 858, 859 (Del. 1985) ("competing fiduciary duty" clause in merger agreement does not on its face allow target directors to accept a higher offer). After their financial advisors analyzed the tender offer, the Crouse-Hinds directors recommended that their shareholders reject the offer on its merits. Crouse-Hinds, 634 F.2d at 694-95. 
The notion that target directors must honor contractual agreements by continuing to recommend mergers to shareholders in the face of superior offers, as suggested in the Crouse-Hinds cases, does not square either with a common sense understanding of directors' fiduciary duties to shareholders or with the regulatory requirements of the federal securities laws. It is anomalous to suggest that target directors could recommend approval of a merger in the face of a competing bid that better served the shareholders' interests, ${ }^{184}$ given that directors cannot lawfully contract away their fiduciary duties of care and loyalty. ${ }^{\mathbf{1 8 5}}$ Moreover, the federal proxy rules require the directors to correct any statement in a proxy solicitation, which, while accurate when made, subsequently becomes misleading. ${ }^{186}$ These considerations suggest that courts, in directly addressing this issue, are likely to reject the CrouseHinds dicta ${ }^{187}$ in favor of the analysis presented in Great Western and its progeny.

The presence of no-shop covenants in a merger agreement presents a slightly different issue. ${ }^{188}$ The directors' fiduciary duties should override the literal terms of a contractual best-efforts covenant. The proper relationship, however, between the directors' fiduciary duties and noshop covenants is unclear, given differing views on whether such covenants hurt or benefit target shareholders.

In Jewel Cos., the major case to discuss no-shop covenants on their

184 This assumes of course that the competing offer is, in fact, superior. This judgment will no doubt be considered a business judgment of the board, protected by the business judgment rule in the absence of self-dealing or gross negligence. See, e.g., Crouse-Hinds, 634 F.2d at 702 (absent bad faith or fraud, directors are presumed to have acted properly and in good faith); see also supra notes 25-29 and accompanying text (discussing the business judgment rule).

iss See Restatement (SeCOND) of Contracts, supra note 136, § 193 ("A promise by a fiduciary to violate his fiduciary duty or a promise that tends to induce such a violation is unenforceable on grounds of public policy."); see also Jewel Cos., 741 F.2d at 1563 (directors cannot lawfully contract away their fiduciary duties); Great Western, 200 Colo. at 187, 613 P.2d at 878 (concluding that a best efforts clause could not have been intended to impose any obligation on the target directors that would conflict with their legal duties to the shareholders).

${ }^{186}$ See, e.g., SEC Rule 14a-9(a), 17 C.F.R. § 240.14a-9(a) (1987).

187 Neither the Belden nor the Crouse-Hinds opinions discussed how a target board could comply with its fiduciary duties or the federal proxy rules if it were contractually bound to recommend a merger proposal regardless of intervening events that made the proposal less attractive. This question was specifically reserved by the court in Jewel Cos.. 741 F.2d at 1564 n.13.

188 There is, of course, no sharp line which divides best efforts covenants, no-shop covenants, or other exclusive merger provisions. See supra notes 129-30. For example, directors' best efforts obligations could implicitly include the duty not to seek competing bids. For present purposes, this Article assumes that best efforts and no-shop covenants are, in fact, different undertakings and that the no-shop prohibition includes a ban on giving nonpublic information concerning the target to competing bidders. 
own merits, ${ }^{189}$ the court held that:

[T]o permit a board of directors to decide that a proposed merger transaction is in the best interests of its shareholders at a given point in time, and to agree to refrain from entering into competing contracts until the shareholders consider the proposal, does not conflict in any way with the board's fiduciary obligation. ${ }^{190}$

Thus, the court held that fulfillment of an exclusive merger agreement would not necessarily conflict with the board's fiduciary duties. ${ }^{191}$ One scholar has criticized this aspect of Jewel Cos. for its implicit acceptance of the "anti-auction theory" as the preferred model to further the best interests of target shareholders. ${ }^{102}$

The anti-auction theory, originally developed to refute the validity of tender offer defensive tactics, posits that shareholders are best served by rules that encourage takeovers because takeovers police and ultimately discipline inefficient target management. ${ }^{193}$ Proponents of this theory argue that target managers should neither resist takeovers nor facilitate auctions for the target by seeking competitive bids. The antiauction theory asserts that auctions, which raise the premiums paid by acquiring companies, increase the cost of takeovers and disadvantage initial bidders, who may be unable to recover their search costs. Thus, the anti-auction theory reasons that while auctions may increase the tender offer premium in any one case, auctions, as a practice, reduce

189 There was not an explicit no-shop covenant in the Jewel/Pay Less merger agreement. The merger agreement did, however, prohibit the Pay Less board from altering the capital structure of the target or entering into any contracts outside of the ordinary course of business. The court remanded to the trial court the question of whether the merger agreement was in fact exclusive. Jewel Cos., 741 F.2d at 1569. The case was subsequently settled before this issue was resolved. In Revlon, Inc. v. MacAndrews \& Forbes Holdings, Inc., 506 A.2d 173 (Del. 1986), the court invalidated a noshop provision that was tied to an illegal lock-up. See infra notes 204-10 and accompanying text.

180 Jewel Cos., 741 F.2d at 1563 (citation omitted).

101 In fact, the court noted that an exclusive merger agreement might be required in order for the directors to fulfill their fiduciary duties:

An exclusive board-negotiated merger agreement may confer considerable benefits upon the shareholders of a firm. A potential merger partner may be reluctant to agree to a merger unless it is confident that its offer will not be used by the board simply to trigger an auction for the firm's assets. Therefore, an exclusive merger agreement may be necessary to secure the best offer for the shareholders of a firm.

Id. (citation omitted).

${ }_{182}$ See Buxbaum, supra note 24, at 1698-1709.

193 The disciplinary role of the market for corporate control was first articulated in Manne, Mergers and the Market for Corporate Control, 73 J. PoL. Econ. 110 (1965). 
the number of potential bidders in the marketplace to the ultimate detriment of target shareholders. ${ }^{194}$

As applied to negotiated mergers, the anti-auction model suggests that an initial acquiring company will neither invest the time and money necessary to evaluate a merger partner nor put forth its best offer without some assurance that its bid will not open an auction for the target. While shareholders may ex post benefit from the increased price resulting from an auction for their shares, the anti-auction model proposes that ex ante ${ }^{\mathbf{1 9 5}}$ shareholders would benefit ultimately from a rule that preserves maximum incentives for bidders. The court in Jewel Cos. implicitly recognized the validity of the anti-auction theory by holding that no-shop covenants, which limit auctions, are perfectly consistent with the directors' fiduciary duties to serve the best interests of their shareholders. ${ }^{186}$

The anti-auction theory, however, is a strange candidate to justify no-shop covenants in negotiated transactions. ${ }^{197}$ The theory was originally developed as part of a model urging management passivity in the face of a hostile tender offer. The sanctioning of no-shop covenants in a negotiated merger agreement would augment, rather than diminish, the directors' powers in a merger transaction. The application of the antiauction premises to mergers is also troublesome because the replacement of inefficient target management, the benchmark of the anti-auction theory, is an unlikely motivation for a negotiated merger. ${ }^{198}$

184 See generally Easterbrook \& Fischel I, supra note 42, Easterbrook \& Fischel II, supra note 70 (responding to criticism of Easterbrook and Fischel I); Easterbrook \& Fischel, Corporate Control Transaction, 91 YALE L.J. 698 (1982) [hereinafter Easterbrook \& Fischel III].

198 "Ex post" refers to the time period after a merger proposal has been presented to and accepted by the target board; "ex ante" refers to the time period before an initial offer has been made.

${ }^{196}$ See Jewel, 741 F.2d at 1563.

197 Indeed, one would suspect that proponents of the anti-auction model, and the model favoring managerial passivity to which it is related, would not favor augmenting the power of target directors by allowing of exclusive merger provisions such as noshop covenants.

${ }^{108}$ A 1981 study by Touche Ross \& Co. indicates that most acquiring companies are attracted to targets with excellent, as opposed to inefficient, management. See Coffee, supra note 13, at 1211-12 (citing Touche Ross \& Co., The Effect of MergERS, ACQuisitions, and Tender OfFers on AMERICAN Business: A TOUCHe Ross SuRvey of Corporate Directors' Opinions 12 (1981)); see also Leebron, supra note 1, at 204-05 nn.177-78 (summarizing other recent evidence that indicates that mergers are not explained primarily by the inefficient management hypothesis). Other traditional and more plausible explanations for a negotiated merger include the potential for synergistic gains and financial economies as well as size maximization goals of the acquiring company's management. Synergistic gains can result from a number of factors independent of the inefficient management thesis: vertical integration, economies of scale, combination of complementary product lines, union of complementary manage- 
Therefore, while no-shop covenants may indeed be a necessary incentive to lure reluctant merger partners, ${ }^{199}$ the anti-auction theory itself does not provide a sound basis for concluding that such covenants are consistent with the fiduciary duties of target directors. ${ }^{200}$

Critics of the anti-auction thesis, many of whom agree that tender offers increase shareholder wealth and result in greater management accountability, reject the premise that either shareholders or society benefits by maximizing the number of acquisitions at reduced premiums. ${ }^{201}$ Critics argue that the anti-auction rationale overstates the importance of rewarding initial search costs. Instead, critics posit an auction model as the method that maximizes shareholder and societal wealth. As applied to negotiated acquisitions, the auction model suggests that shareholders are best served by limiting the directors' role to a gatekeeping function consisting of the initial negotiation and evaluation of merger proposals. ${ }^{202}$ Under the auction model, directors could not, consistent with their fiduciary duties, enter into no-shop covenants that would prohibit the facilitation of competing merger bids. ${ }^{203}$

ment teams, and operating efficiencies that reduce expenses. In addition, a merger can produce financial economies through diversification, tax incentives, changes in capital structure, and paper gains due to accounting conventions. The literature describing and analyzing these motivations for corporate acquisitions is voluminous. For recent and concise descriptions of these motivations with citations to the economics literature, see Leebron, supra note 1, at 200-05. See also Coffee, supra note 13, at 1166-75, 1211-15 (outlining and offering criticisms of these explanations). Another theory of acquisitions is that acquiring firm managers interested in personal power, prestige, and compensation tend to maximize size, rather than profits. See, e.g., R.A. GoRdon, Business LEADERSHIP IN THE LARGE CORPORATION 305-12 (1945). Greater size can also translate into greater market power. See Leebron, supra note 1, at 203-04; see also Coffee, supra note 13, at 1167-69 (summarizing the literature supporting this size maximization theory). Moreover, even if one accepts the inefficient management hypothesis to explain hostile takeovers, in a negotiated transaction the acquiring company must negotiate merger terms with the same inefficient managers whose displacement is sought. This suggests limiting, rather than augmenting, the power of target managers.

189 See infra notes 350-61 and accompanying text.

200 Buxbaum, for example, argues that the anti-auction rationale as applied to statutory mergers is subject to several objections: (1) by analogy to antitrust law, such arrangements decrease competition in the market for firms; (2) the efficient stock market rationale underlying the anti-auction model is inconsistent with the model's concern with search costs; (3) the efficiency-sanctioned search process is undermined when hypothetically inefficient managers are the bargaining agents but have little incentive to bargain hard; and (4) the anti-auction model breaks down if an initial expression of interest is made without price terms. See Buxbaum, supra note 24, at 1709-13.

201 See generally Bebchuk I, supra note 70; Comment, The Case of Facilitating Competing Tender Offers, 95 HaRv. L. REv. 1028 (1982) (authored by Lucian A. Bebchuk) [hereinafter Bebchuk II]; Gilson I, supra note 13, at 870-75; Gilson II, supra note 70 , at 62-67.

202 See Buxbaum, supra note 24 , at 1698-1709.

203 A pure auctioneering rule would require all potential bidders to be treated equally by target management in terms of information supplied. See Bebchuk II, supra note 201 , at $1036 \mathrm{n} .44,1054-56$. Such a rule would invalidate those no-shop covenants 
The Delaware Supreme Court recently invalidated a no-shop covenant in a merger agreement because it interfered with the directors' auctioneering role. In Revlon, Inc. v. MacAndrews \& Forbes Holdings, Inc., ${ }^{204}$ the target directors approved a merger agreement designed to thwart a hostile tender offer. The court held that having authorized the sale of the target, "[ $t]$ he directors' role changed from defenders of the corporate bastion to auctioneers charged with getting the best price for the stockholders . . ."20s The court enjoined a lockup option and related no-shop covenant and cancellation fee that, in the court's opinion, prematurely ended the competitive bidding in violation of the directors' fiduciary duties. ${ }^{208}$ The court in Revlon thus held that the directors' fiduciary obligations, once they decided to sell the target company, were limited to securing the best price for target shareholders. This principle applies to all merger transactions, which inherently involve the sale of the target. ${ }^{207}$. Revlon should not be read, however, as an implicit adoption of the auction model as the preferred method of benefiting target shareholders. While the Revlon opinion speaks in terms of an "auction," the court was addressing a situation in which an ongoing auction existed. The court did not address the desirability of an auction per se as the best way to maximize price for target shareholders. ${ }^{208}$ Revlon merely indicates that in an auction setting, the validity of no-shop covenants will depend upon their effect on the bidding process. ${ }^{209}$ Revlon, therefore, sheds little light upon the legal effect of noshop provisions given to entice the initial bid. ${ }^{210}$ The auction/anti-auc-

that guarantee to one bidder sole access to confidential information.

204506 A.2d 173 (Del. 1986).

${ }^{205} I d$. al 182 (emphasis added).

${ }^{206}$ See also Hanson Trust PLC v. ML SCM Acquisition, Inc., 781 F.2d 264, 277, 281 (2d Cir. 1986) (court invalidated lock-up option because it foreclosed competitive bidding for the target).

${ }^{207}$ In Jewel Cos., the court specifically rejected a per se auctioneering requirement: "[W]e are convinced . . . that the Corporate Code of California does not adopt the auction model in regulating negotiated acquisitions." $741 \mathrm{~F} .2 \mathrm{~d}$ at 1562; $c f$. Freedman v. Restaurant Assocs. Indus., Inc., slip op., No. 9212, at 23 (Del. Ch. Oct. 16, 1987) (applying the business judgment rule, the court denied the plaintiff's request for a mandatory injunction to compel the target to grant a lock-up in order to obtain a higher bid).

${ }^{208}$ While the Revlon case involved a merger utilized as a tender offer defensive tactic, its principles apply as well to uncoerced merger transactions. Obviously, there is no bright line separating defensive mergers, such as the merger evaluated in Revlon, from uncoerced combinations, given that even the threat of a hostile takeover may compel target management to consider a negotiated transaction.

${ }^{209}$ The same rule applies with perhaps more force to lock-ups and cancellation fees. See Hanson, 781 F.2d at 273-74; Revlon, 506 A.2d at 183-84; infra notes 212-23 and accompanying text.

${ }^{210}$ Revlon and Hanson speak only to the necessity of conducting an auction ex post, that is, once an initial bid has been received. See Hanson, 781 F.2d at 273-74, 
tion debate and its relationship to the directors' fiduciary duties in a merger transaction thus remain unresolved. ${ }^{211}$ This uncertainty leaves target directors in a precarious position concerning their rights and duties in fulfilling merger agreements.

\section{Lock-Ups and Cancellation Fees}

Lock-ups and cancellation fees are becoming commonplace in merger agreements. A potential bidder negotiates for these provisions in the hope of ensuring the completion of its acquisition. ${ }^{212}$ A substantial lock-up or cancellation fee can aid in obtaining shareholder approval of the acquisition by making the cost of rejection prohibitive. Shareholders, in effect, face a choice of approving the merger or forcing the target to operate without a prized asset or pay a substantial penalty to the thwarted suitor. To the extent a lock-up or cancellation fee makes a merger a foregone conclusion, it removes any real choice from the shareholders. As such, these provisions could have a pernicious effect upon the structural monitor inherent in corporate statutes. The use of these devices can have a similar deterrent effect upon competing bidders, thus seriously impeding the operation of the market monitor.

Courts, applying a fiduciary duty analysis, have stated consistently that the use of lock-ups or cancellation fees in merger agreements is not per se illegal. ${ }^{213}$ Judicial review has been narrowly confined to an anal-

281; Revlon, 506 A.2d at 183-84. The auction/anti-auction debate, on the other hand, is concerned with the shareholders' interest ex ante, that is, before an initial bid has been made. The debaters thus question whether the interests of shareholders and society will be better served by the auction or anti-auction model when one considers the effect of the chosen model not only upon the premium paid but also upon the probability of an offer being made in the first place. See Bebchuck I, supra note 70, at 27; Easterbrook \& Fischel I, supra note 42, at 1176-78.

${ }^{211}$ In spite of the plethora of literature debating this thesis, commentators candidly conclude that they have little data with which to support their varying positions. See, e.g., Easterbrook \& Fischel II, supra note 70, at 21 ("Although we have not proved that a no-auction rule maximizes the wealth of investors and society, we think the case strong."); Bebchuck I, supra note 70, at 49 ("I [admit] that no conclusive proof can be offered that the positive effects of competition among acquirers outweigh its possibly adverse effect on the number of acquisitions."); see also Haddock, Macey \& McChesney, Property Rights in Assets and Resistance to Tender Offers, 73 VA. L. REV. 701, 741 (1987) ("Neither the proponents nor the opponents of managerial bargaining have provided quantitative evidence to support their position.").

${ }_{212}$ But see DMG v. Aegis, No. 7619, slip op. at 6-7 (Del. Ch. June 29, 1984) (expressing doubt that the stock options and cancellation fee truly were motivated by the recipient's desire to complete the acquisition).

${ }^{213}$ Generally, courts have examined lock-ups from two perspectives: (1) the adequacy of the consideration for a lock-up, see, e.g., Revlon, 506 A.2d at 184; DMG, slip op. at 6-7; and (2) the adequacy of the consideration for the purchase of the underlying target stock or assets, see, e.g., Hanson, 781 F.2d at 275-76; Buffalo Forge Co. v. Ogden Corp., 555 F. Supp. 892, 904-05 (W.D.N.Y. 1983), affd, 717 F.2d 757 (2d 
ysis of the care with which the directors made the decișion concerning the lock-up or cancellation fee. When adopted as a part of a negotiated merger agreement, the courts have shown deference to a reasonable exercise of judgment by the directors in granting the lock-up or cancellation fee in exchange for the initial bid. ${ }^{214}$ Arguments suggesting that such devices illegally coerce a shareholder vote or interfere with the market of competing bidders have not fared well. ${ }^{215}$ Some courts, however, have been more critical of such provisions if they are granted to one bidder in the midst of a battle for control of the target. In Revlon and Hanson Trust PLC v. ML SCM Acquisition, Inc., ${ }^{\mathbf{2 1 8}}$ the courts invalidated lock-ups because the courts found that they stifled competitive bids in violation of the directors' fiduciary duty to obtain the best price for their shareholders ${ }^{217}$

The Revlon and Hanson opinions, however, lack coherent standards to guide future parties to a merger. First, it is unclear what fiduciary duty was violated by the target directors in Revlon and Hanson. While both opinions speak in terms of a duty of care violation, the courts actually appeared more concerned with duty of loyalty issues. ${ }^{218}$ Moreover, there are serious problems with the Revlon and Hanson courts' attempted distinctions between "good" lock-ups, which encourage competitive bids, and "bad" lock-ups, which effectively preclude competitive bids. ${ }^{\mathbf{2 1 0}}$ The obvious difficulty with these overly sim-

Cir. 1983), cert. denied, 464 U.S. 1018 (1983); Whittaker Corp. v. Edgar, 535 F. Supp. 933, 944-49 (N.D. Ill. 1982); Revlon, 506 A.2d at 184. See generally Fiduciary Duties, supra note 57 , at 83-102.

${ }_{214}$ See, e.g., Hecco Ventures v. Sea-land Corp., No. 8486 (Del. Ch. May 19, 1986) (LEXIS, States library, Del. file) (lock-up option granted at the conclusion of an auction to the highest and only remaining bidder was not a violation of the directors' fiduciary duties); Thompson v. Enstar Co., 509 A.2d 578, 583-84 (Del. Ch. 1984) (directors did not violate their fiduciary duties in granting lock-up option to the only firm bidder).

${ }^{215}$ See, e.g., Buffalo Forge, 555 F. Supp. at 905 (W.D.N.Y. 1983) (The court found that the lock-up option did not circumvent shareholder voting rights because it was not contained in the plan of merger requiring shareholder approval.); Friedman v. Baxter Travenol Laboratories, Inc., No. 8209, slip op. at 4-5 (Del. Ch. 1986) (The court, concerned with the underlying motive, rather than the effect, of a cancellation fee, noted the absence of any legal authority to support the vote-coercion claim.); Thompson, 509 A.2d at 583-84 (While recognizing that lock-ups infringe upon the shareholders' voting rights, the court nevertheless upheld the lock-up under the business judgment rule.).

216781 F.2d 264 (2d Cir. 1986).

217 See id. at 281-83; Revlon, 506 A.2d at 183-85.

218 See supra notes 77, 98-104 and accompanying text; see also Data Probe Acquisition Company v. CRC Information Sys., No. 92133-1983 (N.Y. Sup. Ct. Dec. 11, 1984) (lock-up violated target directors' duty of loyalty because the lock-up decision was motivated primarily by directors' desires to obtain employment contracts with option grantee).

218 Hanson, 781 F.2d at 274; Revlon, 506 A.2d at 183. 
plistic distinctions is that a lock-up is a double-edged sword. On the one hand, a lock-up can serve as quid pro quo for a higher offer. On the other hand, however, an effective lock-up granted to one bidder simultaneously forecloses competitive offers from other potential bidders. Unfortunately, it is ordinarily possible to judge the results of the directors' decisions in this area only with the benefit of hindsight. In those situations where the lock-up in fact enticed the highest bid, it was a good lock-up; if, however, the lock-up enticed a somewhat higher bid but foreclosed a subsequent bid that was even higher, it was a bad lockup. ${ }^{220}$ Except for egregious cases, ${ }^{221}$ courts, in attempting to apply the Revlon/Hanson lock-up test, will end up second-guessing what are essentially business decisions. This is an endeavor that the courts are neither inclined nor equipped to handle. ${ }^{222}$ This situation has led one commentator to remark: "Thus, traditional business judgment analysis of lock-ups results in no review, while more rigorous review seems to take the form of a judicial search for a unicorn, an attractive beast to be sure, but one whose combination of attributes exists only in mythology."223

In sum, judicial review of exclusive merger covenants has produced both varying and inconsistent results. Largely proceeding under a fiduciary duty analysis, the courts have shown little concern for the effect of their decisions upon the structural or market monitoring devices. Even under fiduciary duty standards, the underlying rationales of the opinions appear confused and at times disingenuous. The judicial inability to formulate consistent standards may be due to the courts' professed reluctance to second-guess, or appear to be second-guessing, the directors' business decisions. This is not to suggest, however, that

${ }^{220}$ The difficulty inherent in Revlon's attempted distinction between good and bad lock-ups has been recognized by the Delaware Chancery Court, see Freedman v. Restaurant Assocs. Indus., Inc., slip op., No. 9212, at 17 n.3 (Del. Ch. Oct. 16, 1987) ("Of course, even when designed to promote another bid, a good (i.e., effective) lock-up agreement may well end the bidding after that one last bid it induces is on the table. Thus, the implications of the distinction that Reolon draws have yet to be fully worked out.").

${ }_{221}$ The lock-up in Revlon, perhaps, exemplifies such an egregious case in that the competitive bidder, Pantry Pride, had announced that it would top any offer made by Forstman Little, the "white knight" bidder favored by target management. See Revlon, 506 A.2d at 178. Despite this announcement, Revlon granted Forstman Little a lock-up along with a related no-shop promise and cancellation fee. Revlon, $506 \mathrm{~A} .2 \mathrm{~d}$ at 178-79.

${ }^{222}$ See supra note 27 and accompanying text (discussing justifications for the business judgement rule).

${ }_{223}$ R. Gilson, supra note 106, at 843; see also Herzel, Colling \& Carlson, Misunderstanding Lockups, 14 SEC. REG. L.J. 150, 177 (1986) ("Classifying a lockup as a permissible type that promotes bidding, or a harmful strain that discourages bidding, appears to be no more than conclusory judicial labels that are affixed by hindsight after the lockup has been scrutinized by the courts."). 
more extensive judicial review of directors' merger decisions is necessary or, for that matter, even desirable. To the contrary, we agree that the courts are generally not equipped to undertake a more thorough review. What is needed, instead, is a statutory scheme that retains for directors the needed flexibility to negotiate complex merger transactions without sacrificing the effective operation of the structural and market monitors upon the directors' decisions. These monitors, if allowed to operate in an unimpeded fashion, will ensure that the target shareholders, not the target board of directors or the courts, make the ultimate determination concerning the merger transaction.

\section{PROPOSAL}

\section{A. The Proposed Rule: A Legislative Model}

The following two-part proposal is designed to serve as a basis for legislation governing the role of target directors in a merger transaction. The first part of the proposal addresses the inherent conflict of interest problem faced by inside target directors in merger transactions by requiring decisions to be made exclusively by "independent" target directors. The second part of the proposal restricts the authority of these independent directors in merger transactions to help ensure the effective operation of the structural and market monitors.

\section{Part One: Independent Directors}

(a) The deliberation, negotiation, and vote to accept or reject a merger proposal $^{224}$ shall be undertaken by a target's ${ }^{225}$ independent ${ }^{226}$ direc-

224 This Article has referred throughout to all acquisitions requiring board and shareholder approval as mergers. See supra note 3. Part One of our proposal applies to mergers as thus defined and also to mergers that may be undertaken without a shareholder vote. See supra note 7. In addition, Part One of the proposal applies to tender offers that are part of an overall acquisition agreement. It is overly simplistic to view negotiated acquisitions as involving either mergers or tender offers. Often, an acquisition agreement will contemplate both a first stage tender offer and a second stage merger. See, e.g., Samjens Partners I v. Burlington Indus., Inc., 663 F. Supp. 614 (S.D.N.Y. 1987) (acquisition agreement provided for tender offer to be followed by a second stage merger). See generally Freund \& Easton, The Three Piece Suitor: An Alternative Approach to Negotiated Corporate Acquisitions, 34 Bus. LAw. 1679 (1979) (discussing multi-step acquisitions including tender offers and mergers). Our proposal thus differs from requirements imposed by current federal regulations regarding disclosure of securities transactions that vary according to the form of the negotiated transaction. Disclosure regarding mergers is regulated primarily under $\S 14$ (a) of the 1934 Act and the SEC proxy rules promulgated thereunder, 17 C.F.R. $\S 240.14$ (a) (1987), while the Williams Act, 15 U.S.C. $\$ \S 78 \mathrm{~m}(d)(E), 78 \mathrm{n}(\mathrm{d})-(\mathrm{f})(1982$ \& Supp. III 1985), governs tender offers. The application of these differing regulations results in different timing and disclosure requirements depending upon the form of a negotiated 
tors, as long as there are at least three such directors. Merger decisions shall be made by a majority vote of all independent directors.

(b) "Independence" means the absence of either a potential monetary interest in the merger or a familial relationship to a nonindependent director or officer. "Potential monetary interest" shall not include either: (1) loss of one's directorship or; (2) financial gain resulting from one's proportional ownership of target stock. Directors, however, who are also officers of the target, shall not qualify as independent.

(c) Directors have the burden of proving only their independence as defined in (b) above.

(d) The target corporation shall bear the burden of proving the fairness of merger decisions made without complying with (a) above.

\section{Part Two: The Permissible Boundaries of Merger Covenants}

(a) Directors of a target corporation are authorized to bind their corporation to covenants in merger agreements except for: (1) essential merger terms; and (2) any covenants that limit or otherwise interfere with the directors' obligations set forth in paragraph (c) below. A "merger agreement" encompasses agreements negotiated in connection with both mergers and tender offers.

(b) Shareholders who are entitled to vote on the merger must approve all essential merger terms, and no essential merger term is valid prior to the shareholders' vote. Essential merger terms include lock-ups, cancellation fees, and the basic terms of the merger. ${ }^{227} \mathrm{~A}$ "lock-up" is a

acquisition. This anomaly has been extensively criticized for elevating form over substance. See generally Freund \& Greene, Substance over Form S-14: A Proposal to Reform SEC Regulation of Negotiated Acquisitions, 36 Bus. LAw. 1483 (1981) (suggesting uniform SEC regulation of negotiated tender offers and mergers to avoid elevating form over substance and to eliminate problems inherent in current disclosure regulations); Greene \& Junewicz, A Reappraisal of Current Regulation of Mergers and Acquisitions, 132 U. PA. L. REv. 647, 695-700 (1984) (recommending that federal regulations not distinguish between forms of negotiated acquisitions). Similarly, the SEC Tender Offer Advisory Committee recommended that in regulating control transactions, the SEC address all acquisition techniques, see ADVISORY COMM. ON TENDER OfFers, U.S. SEC. \& EXChange Comm'n, RePoRT OF Recommendations, Recommendation No. 10 (July 8, 1983) [hereinafter SEC TENDER OFFER REPORT], a recommendation endorsed by the Commission. See Statement of SEG Chairman John S.R. Shad before the House Subcomm. on Telecommunications, Consumer Protection and Finance Concerning the Recommendation of the SEC Advisory Committee on Tender Offers, [1983-1984 Transfer Binder] Fed. Sec. L. Rep. (CCH) II 83,511, 86,678 (Mar. $28,1984)$.

${ }_{225}$ See supra note 6 (defining "target corporation").

${ }^{228}$ This Article uses the term "independent" to denote both independence and disinterest. See infra notes 264-74 and accompanying text (discussing case law definition of "independence" and "disinterest").

${ }^{227}$ See supra notes 123-32 and accompanying text (distinguishing routine house- 
provision under which the target: (1) disposes or agrees to dispose of target voting stock or securities convertible into such stock that would result in more than a $15 \%$ increase in the target's outstanding voting shares; or (2) disposes or agrees to dispose of target assets, other than in the ordinary course of business, when (i) the value of the assets or the sale price exceeds $15 \%$ of the consolidated assets of the target; or (ii) the pretax operating income of the assets exceeds $15 \%$ of the income of the target. ${ }^{228}$ The term "dispose" includes options as well as sales. A "cancellation fee" is any fee in excess of reasonable negotiation expenses, such as attorneys fees, accounting fees, standby financing fees and related items, ${ }^{229}$ which the target agrees to pay to an acquiring company in the event the merger is not completed. ${ }^{230}$

(c) Target directors must disclose to their shareholders accurate and timely information regarding the merger proposal and any competing offers. The directors shall base their recommendation to the shareholders upon all relevant information available at the time of the shareholder vote.

(d) A target corporation that, through the actions of its directors, has agreed to a merger proposal, may not, pending the shareholder vote on the essential terms thereof, engage in any activities designed to deter competing bids. This prohibition includes the implementation of the provisions of applicable state antitakeover statutes. Any defensive tactics that the target may have previously employed must, to the extent the implementation or waiver of such tactic remains under the control of the directors, be uniformly applied or waived for all bidders.

\section{B. Comments on Part One: Independent Directors}

\section{General Comments}

Part One of this proposal is designed to address the inherent conflict of interest faced by a target's inside directors confronted with a merger offer. Judicial review has proven to be an inadequate means of policing the duty of loyalty issues, and the nonjudicial monitors cannot effectively operate in this conflict of interest climate. In merger approval cases, the directors' unavoidable conflict of interest may taint their actions and recommendations, thus undermining the effective operation of the structural and market monitors. In merger rejection

keeping covenants in merger agreements from exclusive merger covenants that negatively impact on the efficacy of the structural and market monitors).

${ }_{228}$ See supra note 131 (providing examples of other lock-up provisions).

${ }^{229}$ See supra note 132 (providing examples of other cancellation fee provisions).

2so See supra note 105 (describing state antitakeover statutes). 
cases, on the other hand, the structural monitor is inoperative by statutory design and the market monitor is of limited utility if the target enacts defensive tactics.

Existing merger statutes, which require target directors to approve a merger proposal, recognize the complexity of mergers and the resulting need for participation by target directors. ${ }^{231}$ These statutes do not, however, reflect any recognition of the potential conflict of interest faced by the target's inside directors. ${ }^{232}$ Our proposed rule, by permitting only independent directors to consider, negotiate, and recommend merger offers, attempts to satisfy the target shareholders' need for director input while preventing participation by those directors who have a potential or actual conflict of interest. The independent directors can both provide the information needed by the bidder and negotiate on behalf of the target shareholders without any conflict of interest.

Both corporate statutes ${ }^{233}$ and the case law ${ }^{234}$ have encouraged the use of independent directors to monitor conflict of interest transactions. For example, the Delaware Supreme Court, in reviewing a potent tender offer defensive tactic, found probative the active role played by the eight outside target directors, who comprised a majority of the thir-

${ }^{231}$ See supra text accompanying notes 18-19 (discussing the role of target directors in a merger transaction).

${ }^{232}$ In the tender offer area, some scholars have proposed resolving the inside directors' conflict of interest by requiring target management passivity. See Easterbrook \& Fischel I, supra note 42, at 1194; Gilson I, supra note 13, at 878-79; see also Siegel, supra note 27, at 410 (advocating that to obviate conflicts of interest, directors should submit all defensive tactic proposals to shareholder vote). The statutory powers of the directors, however, have prevented parallel suggestions to limit their role in a merger transaction. But see Buxbaum, supra note 24, at 1698-1713 (arguing that recent judicial interpretations of directors' merger powers undercut shareholder voting rights).

${ }^{233}$ See, e.g., Del. Code ANn. tit. 8, § 144(a)(1) (1983) (stating that a conflict of interest transaction is not void or voidable if a majority of the disinterested directors approve the transaction); MBCA, supra note $3, \S 41$ (stating that a conflict of interest transaction is not void if the conflict is disclosed to the board of directors and approved by a sufficient number of disinterested directors' votes); RMBCA, supra note 3, $\S 8.31$ (c) (conflict of interest transaction is authorized, approved or ratified if approved by majority of directors who have no direct or indirect interest in the transaction).

${ }^{234}$ See, e.g., Rosenblatt v. Getty Oil Co., 493 A.2d 929, 937 (Del. 1985) (stating that fact that directors were independent was a crucial factor in concluding that transaction was fair); Aronson v. Lewis, 473 A.2d 805, 812 (Del. 1984) (stating that in a derivative action, the transaction must be approved by a majority consisting of independent directors for the business judgment rule to be applicable); Weinberger v. UOP, Inc., 457 A.2d 701, 709 n.7 (Del. 1983) (suggesting that parent corporation might have been able to prove fairness of merger with its subsidiary if independent committee of outside directors had been appointed to negotiate on behalf of the subsidiary); Auerbach v. Bennett, 47 N.Y.2d 619, 632, 393 N.E.2d 994, 1001, 419 N.Y.S.2d 920, 927 (1979) (noting that as independent directors made up special litigation committee, presumption was they could recommend dismissal of derivative action); see also supra note 120 (discussing use of outside directors in corporate control transactions). 
teen directors present at the board meeting. ${ }^{235}$ The outside directors met separately with the target corporation's advisors and attorneys and then unanimously agreed to advise the board to fight the tender offer. The court held that the directors' burden to prove their good faith and reasonable investigation was "materially enhanced . . . by the approval of a board comprised of a majority of outside independent directors." ${ }^{236}$

Similarly, in Weinberger $v$. UOP, Inc., ${ }^{237}$ the Delaware Supreme Court suggested that in a parent-subsidiary merger, significant benefits could be derived from using a negotiating committee comprised of the subsidiary's independent directors. In Weinberger, Signal Corporation attempted a cash-out merger of its subsidiary, UOP. The court found that Signal, the majority shareholder, failed in many respects to deal fairly with the minority shareholders of the subsidiary. ${ }^{238}$ The court, in dicta, stated:

Although perfection is not possible, or expected, the result here could have been entirely different if UOP had appointed an independent negotiating committee of its outside directors to deal with Signal at arm's length. Since fairness in this context can be equated to conduct by a theoretical, wholly independent, board of directors acting upon the matter before them, it is unfortunate that this course apparently was neither considered nor pursued. ${ }^{\mathbf{2 3 9}}$

2ss Unocal Corp. v. Mesa Petroleum Co., 493 A.2d 946, 950 (Del. 1985).

${ }^{238} I d$. at 955 . See supra note 120 (discussing role of outside directors in corporate control transactions).

2s7 457 A.2d 701 (Del. 1983).

${ }^{238}$ Among the deficiencies the court found were Signal's inadequate disclosure to the minority shareholders, short notice given to UOP's board, the limited negotiations over the merger terms, and the dubious value of the hastily prepared fairness opinion given by the board's investment banker. Id. at 711-12.

${ }^{239} I d$. at 709-10 n.7 (emphasis added) (citations omitted). The court continued: "Particularly in a parent-subsidiary context, a showing that the action taken was as though each of the contending parties had in fact exerted its bargaining power against the other at arm's length is strong evidence that the transaction meets the test of fairness." Id. (citations omitted). Similarly, the court in Samjens Partners I v. Burlington Indus., Inc., 663 F. Supp. 614 (S.D.N.Y. 1987), appeared swayed by the fact that the merger negotiations, which arguably included incentives for the target's inside directors, were carried out by the senior outside director. $I d$. at 624 . Moreover, all relevant decisions were made by the outside directors who were advised by outside counsel and investment bankers. Id.

In Rosenblatt v. Getty Oil Co., 493 A.2d 929 (Del. 1985), the court upheld a parent-subsidiary merger because the court felt the merger was fair. Part of the court's holding was predicated on its belief that the majority, Getty, dealt fairly with the minority because the corporation formed an independent bargaining structure. Specifically, potential conflicts among interlocking managements were resolved, and the outside directors were active in questioning and, eventually, in approving the merger. Id. at 938-39. The court concluded, "what we have here is more than the theoretical 
Weinberger thus suggests that a corporation utilize its independent directors to alleviate the conflict of interest inherent in parent-subsidiary merger negotiations.

Weinberger is a compelling analogy to our proposal because that case involved a merger in which the majority of the subsidiary's directors had a conflict of interest. It is particularly significant that the court believed that the minority shareholders needed the protection afforded by independent directors even though the merger had been conditioned on securing the approval of a majority of UOP's minority shareholders. ${ }^{240}$ Presumably, the court believed that the shareholders could only accept or reject the merger offer, while the independent directors could have engaged in negotiations to secure the best price. ${ }^{211}$ Other courts have also suggested that the independent directors should represent the shareholders in situations where some of the directors have a conflict of interest. $^{242}$

Scholarly criticism of the court's proposal in Weinberger usually focuses on the feasibility of arms-length negotiations in a parent-subsidiary merger. Critics argue that it is unrealistic to expect effective bargaining where one group of directors negotiates against its fellow directors. ${ }^{243}$ Critics also argue that the courts cannot expect the parent corporation both to negotiate at arms-length and to fulfill the disclosure

concept of what an independent board might do under like circumstances." Id. at 937; cf. Rabkin v. Philip A. Hunt Chem. Corp., 498 A.2d 1099, 1106 n.7 (Del. 1985) (stating that the court will not announce any rule, even in the current context of a motion to dismiss, that absence of an independent negotiating committee will preclude dismissal in cases predicated on unfair dealing by controlling shareholders).

${ }_{240}$ In Weinberger, the court found that since the disclosure to the minority shareholders was faulty, their approval was meaningless. 457 A.2d at 712 . The court, however, did not indicate that the minority shareholders would have been fully protected had they been permitted to vote after a full and fair disclosure. Instead, the court in dicta argued that the shareholders would have benefited from independent directors negotiating on their behalf. Id. at 709 n. 7; see also infra notes 243-45 and accompanying text (discussing viability of independent negotiating committee).

241 The court's emphasis on the director's role may result from the belief that shareholders vote as their directors recommend. See Weiss, Balancing Interests in Cash-Out Mergers: The Promise of Weinberger v. UOP, Inc., 8 DEL J. CoRP. LAw 1, 50-51 (1983). On the other hand, former SEC Commissioner Longstreth has argued that independent directors do not provide much protection for their shareholders because the directors invariably have some business or personal connection with the corporation's management that prevents them from acting independently. See Longstreth, Fairness of Management Buyouts Needs Evaluation, Legal Times, Oct. 10, 1983, at 20 , col. 1 ; infra notes 246-55 and accompanying text (discussing structural bias).

242 See supra note 234; see also Rosenblatt v. Getty Oil Co., 493 A.2d 929, 938 n.7 (Del. 1985) (finding that independent negotiating committee helped provide fair merger).

${ }_{243}$ See Weiss, supra note 241, at 53 (arguing that courts should be satisfied that fair dealing has occurred only when independent directors have sought outside expert advice as to the price a third party would be willing to pay). 
obligations required of a majority shareholder. ${ }^{244}$ None of these criticisms, however, relates to the basic issue of disqualifying directors who are not independent. Our proposal, by assigning the independent directors the task of representing target shareholders, effectively neutralizes the conflict of interest of target directors. Moreover, these criticisms of the Weinberger solution are particularly inapplicable to a merger in which the target's independent directors negotiate with an outside bidder. ${ }^{245}$

Our proposal, while not subject to the criticisms of the Weinberger solution, nevertheless raises other concerns. The possibility exists that independent directors would change the appearance, but not the reality, of the board's decisionmaking process. That result would do little to aid target shareholders, and significant duty of loyalty concerns would remain unaddressed. Representation of shareholders by independent directors is a viable solution only if the directors are effective independent performers.

In this regard, some have argued that the term independent director is an oxymoron because a "structural bias" prevents any director from being truly independent. Proponents of the structural bias theory posit that this bias stems primarily from two factors: (1) corporate managers select the outside directors and decide whether or not these directors are to be retained; ${ }^{\mathbf{2 4 6}}$ and (2) managers select outside directors who are also corporate managers, so that the outside directors are predisposed to be sympathetic to management's views. ${ }^{247}$ In essence, proponents of the structural bias theory believe that directors cannot be independent because all directors are "economically or psychologically dependent upon or tied to the corporation's executives, particularly its

244 See Note, Payson \& Inskip, Weinberger v. UOP, Inc.: Its Practical Significance in the Planning and Defense of Cash-Out Mergers, 8 DeL. J. CoRP. L. 83, 8889 (1983); Note, Corporation Law-Weinberger v. UOP, Inc.: Delaware Reevaluates State-Law Limitations on Take Out Mergers, 62 N.C.L. REv. 812, 828 (1984).

${ }^{245}$ Some acquisitions, however, will not involve outside bidders but will be the target's own managers, engaging in a leveraged buy out. For a discussion of leveraged buy outs, see Booth, supra note 100 .

${ }^{246}$ Chittur, Ventriloquism for Corporate Directors: Special Litigation Committees in Derivative Suits, 9 CORP. L. REv. 99, 116 (1986).

247 Id.; see also Brudney, The Independent Director-Heavenly City or Potemkin Village?, 95 HARV. L. REv. 597, 610-11 (1982) (asserting that structural bias exists because directors are purposefully selected for having views similar to management's); Cox \& Munsinger, Bias in the Boardroom: Psychological Foundations and Legal Implications of Corporate Cohesion, 48 LAW \& ConTEMP. Probs. 83, 99-100 (Summer 1985) (noting that management chooses directors who share views similar to management's). A third basis for structural bias, namely, an empathetic reaction to management if it is sued, exists in the derivative action context. See Chittur, supra note 246, at 116-18. For an argument that this factor is inapplicable in the merger context, see infra notes $283-84$ and accompanying text. 
chief executive."248

The structural bias theory, however, fails to consider several factors. First, it is unlikely that the typical outside director ${ }^{24 \theta}$ will be completely docile and merely rubberstamp all management decisions. ${ }^{250}$ Furthermore, it is difficult to believe that directors are economically dependent on these relatively low paying positions. ${ }^{251}$ Finally, it is questionable whether corporate directorships are so attractive that outside directors become psychologically dependent on management. ${ }^{252}$ Current statistics that demonstrate the difficulty of attracting directors undermine this theory. ${ }^{25 s}$ Thus, although the structural bias theory has been asserted often, ${ }^{254}$ it is unsupported by statistical evi-

248 M. EISENBerg, supra note 30, at 145; see Cox \& Munsinger, supra note 247, at 85 (noting that both economic and psychological factors affect director independence); see also Brudney, supra note 247, at 622 (discussing limitations on directors' independence imposed by directors' social and economic relationships with management).

249 Many outside directors are business executives. Leech \& Mundheim, The Outside Director of the Publicly Held Corporation, 31 Bus. Law. 1799, 1811 (1976) (citing to study of outside directors in 511 manufacturing companies, where only 39 were professional directors but 759 were either the president or managing partner of other businesses and 605 were board chairpersons); see also supra note 247 (citing articles that suggest that the typical outside director is also a business manager).

${ }^{280}$ Moreover, fear of liability for failing to fulfill their duty of care should cause outside directors to do more than just blindly approve management's recommendations. See, e.g., Smith v. Van Gorkom, 488 A.2d 858, 874-75 (Del. 1985) (holding directors' reliance solely on chief executive violated directors' duty of care). But see supra note 77 (discussing recent enactment of statutes designed to curtail directors' liability for violations of their duty of care).

${ }^{251}$ In a recent study of the Fortune 1000 corporations, in which responses were received from $30.3 \%$ of this group, the mean compensation for outside directors was $\$ 20,534$. Heidrick \& Struggles, The Changing Board 8 (1986). This figure excludes perquisites for outside directors.

${ }^{262}$ But see Dynamics Corp. of Am. v. CTS Corp., 794 F.2d 250, 256 (7th Cir. 1986) (stating that structural bias exists because even outside directors do not like to be fired), rev'd on other grounds, 107 S. Ct. 1637 (1987).

${ }_{253}$ Currently, two out of every three candidates approached by Korn Ferry International, a management recruiting firm, decline board nominations. The liability insurance crisis is largely responsible for this problem. Fowler, Scarce Corporate Directors, N.Y.'Times, Jan. 7, 1986, at D20, col. 1. Another recent study indicated that 7 of 10 responding Fortune 1000 chairmen declined corporate directorships during the 1983-86 period, and 3 of 4 responded that they would not serve on boards that did not offer liability insurance. HeIDRICK \& STRugGLes, supra note 251, at 1; see also Block, Barton \& Radin, Indemnification and Insurance of Corporate Officials, in DIRECTORS' AND OfFICERS' LiABILITY 1986, at 891, 895-96 (Practicing Law Institute Course Handbook Series No. 525, 1986) (indemnification is necessary because the threat of liability discourages potential outside directors).

${ }^{284}$ Most cases arguing that structural bias exists are in the derivative action context. See Hasan v. CleveTrust Realty Investors, 729 F.2d 372, 375-77 (6th Cir. 1984); Joy v. North, 692 F.2d 880, 888 (2d Cir. 1982), cert. denied, 460 U.S. 1051 (1983); Lasker v. Burks, 567 F.2d 1208, 1212 (2d Cir. 1978), rev'd, 441 U.S. 471 (1979); Zapata Corp. v. Maldonado, 430 A.2d 779, 787 (Del. 1981); Miller v. Register \& Tribune Syndicate, Inc., 336 N.W.2d 709, 718 (Iowa 1983); Alford v. Shaw, 358 
dence. $^{285}$

One might also question whether other factors will prevent independent directors from performing their jobs effectively. Professor Brudney contends that outside directors have neither the time nor the critical information necessary to oversee management's performance. ${ }^{258}$ He also asserts that concerns about harm to the corporation resulting from director infighting, lack of strong financial benefits for the independent directors, and structural bias serve to discourage independent directors from vigorously monitoring the insiders. ${ }^{27}$ All of these concerns, however, are inapplicable to an acquisition setting. Independent directors considering merger proposals neither prosecute nor judge any alleged misconduct by their colleagues. Moreover, àcquisition proposals, because of their focus on the potential for self-dealing rather than on management's performance, can be readily delegated to the independent directors. Furthermore, this delegation is for one proposed transaction, rather than a requirement for independent directors to undertake the massive and ambiguous task of monitoring management's general performance. Finally, independent directors' evaluation of merger proposals is a responsibility that they already possess.

We propose that decisionmaking solely by independent directors, subject to some judicial monitoring, can resolve the directors' loyalty problem. Without the impediments imposed by a conflict of interest, the structural and market monitors can operate more efficiently in the merger setting.

S.E.2d 323, 328 (N.C. 1987). A few corporate control cases, however, also presume that structural bias exists. See CTS, 794 F.2d at 256; Hanson Trust PLC v. ML SCM Acquisition, Inc., 781 F.2d 264, 277 (2d Cir. 1986). Some commentators have also noted judicial recognition of structural bias. See Brudney, supra note 247, at 610-614; Chittur, supra note 246, at 118; Cox \& Munsinger, supra note 247, at 108.

${ }^{28 B}$ See Chittur, supra note 246 at 115 (acknowledging that "bias is difficult, if not impossible, to prove in a specific case"); Cox \& Munsinger, supra note 247, at 107-108 (noting that although there are factors that strongly suggest bias in the boardroom, it is difficult to prove).

${ }^{258}$ Brudney, supra note 247 , at 633-34; see also Werner, Corporation Law in Search of Its Future, 81 Colum. L. REv. 1611, 1656-58 (1981) (questioning whether independent directors can fulfill the tasks of monitoring their fellow directors). Professor Brudney also argues that independent directors are not motivated to carefully monitor management because they will not incur any penalty if they perform poorly. Brudney, supra note 247 , at 614 . This is because independent directors have not been held personally liable even in those cases in which their decisions have been overturned. Id. at 615 n.51. Independent directors have, however, been held liable for violating their duty of care in the decisionmaking process. See, e.g., Smith v. Van Gorkom, 488 A.2d 858, 893 (Del. 1985) (all directors, including independent directors, held liable for failing to satisfy their duty of care). But see supra note 77 (discussing enactment of statutes designed to curtail directors' liability for violations of their duty of care).

207 Brudney, supra note 247, at 610-613. 


\section{Defining Independence ${ }^{288}$}

The derivative action cases provide the most well-developed definition of director independence. In Aronson $v$. Lewis, ${ }^{259}$ the plaintiff alleged that the election of all of the board members by a controlling shareholder resulted in a board that was not independent. ${ }^{260}$ The plaintiff thus argued that he was excused from making demand on the board before pursuing his derivative action. ${ }^{261}$ The court held that demand would be excused only when the particular facts alleged create a reasonable doubt that, among other considerations, ${ }^{262}$ the directors were disinterested and independent. ${ }^{263}$

In Aronson, the court defined independence as decisionmaking by directors "based on the corporate merits of the subject before the board rather than extraneous considerations or influences."264 In explaining what would constitute "extraneous considerations or influences," the court stated that the nomination or election of directors by a controlling shareholder would not destroy the presumption that such directors were independent. ${ }^{265}$ In order to destroy this presumption, "[ $\left.t\right]$ here must be coupled with the allegation of control such facts as would demonstrate that through personal or other relationships the directors are beholden to the controlling person."28в Thus, the court required the plaintiff to

${ }^{258}$ The Delaware Supreme Court presumes outside directors are independent. See supra note 120.

289473 A.2d 805 (Del. 1984).

${ }^{260} \mathrm{Id}$. at 809.

${ }^{261}$ Id. Most states require shareholders to make a demand on the corporation's directors prior to filing a derivative suit or state with particularity the reason for not making demand. See D. DeMotT, Shareholder Derivative Actions Law \& Practice $§ 5.03$ (1987); see also FED. R. Crv. P. 23.1 (requiring that complaint allege with particularity the efforts made by the plaintiff to obtain plaintiff's desired action from the directors and, if necessary, the reasons for plaintiff's failure to obtain that action or for not making the effort). Two reasons for the demand requirement exist: first, to give the corporation notice of the suit so that it has the chance to rectify the alleged wrong without litigation; and second, to give the corporation the chance to bring the suit given that derivative actions infringe on directors' statutory authority to manage the corporation. See Aronson, 473 A.2d at $811-12$. Therefore, the demand requirement exists to ensure that shareholders first seek remedies from the corporation before resorting to litigation. Id.

${ }^{202}$ The court in Aronson also required the plaintiff to allege particularized facts creating a reasonable doubt that "the challenged transaction was otherwise the product of a valid exercise of business judgment." 473 A.2d at 814.

${ }^{283}$ Id.; see also supra note 226 (discussing this Article's use of the term "independent" to cover both disinterest and independence).

204 Aronson, 473 A.2d at 816.

208 Id.

${ }^{288}$ Id. at 815. In Lewis v. Fuqua, 502 A.2d 962, 967 (Del. Ch. 1985), the court held that the special litigation committee was not independent. Id. The committee consisted of only one director who was the president of a university whose major donor was the principal defendant in the derivative suit. Id. at 966-67. The court stated, "If a 
allege particular facts demonstrating that the directors' decisions were made in the interest of the controlling shareholder, rather than in the corporation's interest: "The shorthand shibboleth of 'dominated and controlled directors' is insufficient"267 to strip the directors of their presumption of independence. ${ }^{268}$ Some courts have held that directors who have had extensive business dealings with the defendant directors do not lose their independence. ${ }^{268}$ If this reasoning is accepted, extraneous considerations that would disqualify a director would be limited to family, rather than business, relationships. ${ }^{270}$

As a corollary to independence, the court in Aronson also required the directors to be disinterested. "Disinterest," as defined by the court, requires that directors "neither appear on both sides of a transaction nor expect to derive any personal financial benefit from it in the sense of self-dealing, as opposed to a benefit which devolves upon the corporation or all stockholders generally."271 The court held that the directors' approval of the disputed transaction, and the possibility that this might result in their personal liability, were insufficient grounds for challenging either their independence or disinterestedness. ${ }^{272}$ Thus, a director who approves a transaction that later becomes the subject of a derivative action may evaluate that derivative action without being on

single member committee is to be used, the member should, like Caesar's wife, be above reproach." Id. at 967.

${ }^{267}$ Aronson, 473 A.2d at 816.

${ }^{268}$ In Aronson, the Delaware Supreme Court also held that "mere directorial approval of a transaction, absent particularized facts supporting a breach of fiduciary duty claim, or otherwise establishing the lack of independence or disinterestedness of a majority of the directors, is insufficient to excuse demand." Id. at 817; see also supra notes 171-74 and accompanying text (discussing criteria for showing interest).

${ }^{269}$ See, e.g., In re General Tire \& Rubber Co. Sec. Litig. 726 F.2d 1075, 1084 (6th Cir.) (partner in law firm retained by corporation held independent for purposes of serving on special litigation committee), cert. denied, 469 U.S. 858 (1984); Rosengarten v. Buckley, 613 F. Supp. 1493, 1500 (D. Md. 1985) (classifying directors as independent although members of special litigation committee had worked with defendant directors on boards of other corporations); Genzer v. Cunningham, 498 F. Supp. 682, 693-94 (E.D. Mich. 1982) (paid consultant to corporation found to be independent for purposes of serving on special litigation committee); Kaplan v. Wyatt, 499 A.2d 1184, 1190 (Del. 1985) (finding prior business dealing with defendant-director was insufficient to establish bias). But see Fuqua, 502 A.2d at 967 (holding that president of university whose major donor was the principal defendant was not, as the sole member of the special litigation committee, independent).

The American Law Institute supports the Rosengarten decision but rejects the holdings of Genzer and General Tire. See ALI, Principles of Corporate GovernANCE: ANALYSIS AND ReCOMMENDATIONS § 7.11 (Draft No. 6, 1986) [hereinafter ALI DRAFT No. 6].

${ }^{270}$ See infra note 282 (discussing ALI's definition of "independence" to include lack of family relationship to an interested person).

271 Aronson, 473 A.2d at 812.

272 Id. at 815 . 
both sides of the transaction. ${ }^{273}$ Only direct financial benefits will constitute a disqualifying interest. ${ }^{274}$

The Aronson decision has been criticized on two grounds. First, some critics argue that the Aronson standards too easily qualify directors as independent. ${ }^{275}$ Second, some argue that Aronson gives insufficient weight to structural bias. ${ }^{278} \mathrm{~A}$ few courts, for example, have questioned whether structural bias prevents directors elected to the board or appointed to a special litigation committee by directors accused of the

${ }^{273}$ See id. But see Galef v. Alexander, 615 F.2d 51, 60-61 (2d Cir. 1980) ("We are not aware of any case that has determined that [defendant] directors . . who have determined [not to pursue] the claim against them ... do not 'stand in a dual relation which prevents an unprejudiced exercise of judgment.' " (quoting United Copper Sec. Co. v. Amalgamated Copper Co., 244 U.S. 261, 264 (1917)).

${ }^{274}$ See In re General Tire \& Rubber Co. Sec. Litig., 726 F.2d 1075, 1084 (6th Cir.) (deeming that directors who were sued for failure to prevent alleged illegal activity were disinterested because they did not receive any direct benefit from the alleged illegality), cert. denied, 469 U.S. 858 (1984); Lewis v. Anderson, 615 F.2d 778, 782 (9th Cir. 1979) (holding that director who approved employees' stock option plan was qualified to review derivative action challenging the plan because he did not personally receive any stock options), cert. denied, 449 U.S. 869 (1980). Contra Galef v. Alexander, 615 F.2d 51, 60-61 (2d Cir. 1980) (rejecting contention that directors were disinterested to judge the derivative action because they were subject to liability in the action).

For purposes of appearing disinterested in the derivative actions proceeding, it is ideal if the directors deciding whether to pursue the derivative action were not on the board when the questionable transaction occurred. See Rosengarten v. Buckley, 613 F. Supp. 1493, 1500 (D. Md. 1985) (noting that all members of the special litigation committee joined the board after the alleged wrongdoing occurred); Gall v. Exxon Corp., 418 F. Supp. 508, 510 n.2 (S.D.N.Y. 1976) (noting that none of the special litigation committee directors was a member of the board at the time of the alleged wrongdoing); Auerbach v. Bennett, 47 N.Y.2d 619, 631-32, 393 N.E.2d 994, 1001, 419 N.Y.S.2d 920, 927 (1979) (special litigation committee was comprised of three disinterested directors who joined the board after the challenged transactions had occurred).

${ }^{278}$ See Chittur, supra note 246, at 110 (contending that Aronson's criteria for defining independence seem broader than desirable); Note, Articulating a DemandExcused Standard in Stockholder Derivative Suits: Maintaining a Stockholder Voice in Corporate Accountability, 16 RuTGERS L.J. 165, 194-98 \& n.208 (1984) (criticizing the Aronson definition of independence as too broad); see also supra note 269 (indicating ALI's disagreement with some case law applying the Aronson criteria). Despite the criticism that the Aronson standards qualify almost anyone as independent, the Delaware Chancery Court recently has held that plaintiffs' demand was excused. See Good v. Texaco, Inc., No. 7501, slip op. at 12 (Del. Ch. Feb. 19, 1985) (concluding that Texaco board was not disinterested within the meaning of Aronson). Note also that on remand, the plaintiff in Aronson filed an amended complaint which the Chancery Court held excused demand. Lewis v. Aronson, No. 6919, slip op. at 2 (Del. Ch. May 1, 1985); $c f$. Lewis v. Hett, No. 6752, slip op. at 8-10 (Del. Ch. Sept. 4, 1984) (plaintiff met Aronson's criteria to qualify for demand-excused case by alleging facts creating a reasonable doubt that the challenged transaction was not the product of a valid exercise of business judgment).

${ }^{276}$ See Alford v. Shaw, 358 S.E.2d 323, 328 (N.C. 1987); Cox \& Munsinger, supra note 247, at 115-16 (discussing the court's insufficient attention to threat of structural bias). 
wrongdoing can then judge those directors impartially. ${ }^{277}$ As a result of these criticisms, Aronson has not been uniformly followed. ${ }^{278}$

Appropriate application of the principles from the derivative action case law to our merger proposal requires an evaluation of the differences between the two transactions. First, in a merger decision, there is no need for selection among the board members regarding which directors will make the merger decision. Unlike a decision on a derivative action, which ordinarily does not occupy the entire board, a merger decision is normally made by all the directors. ${ }^{279}$ We propose, therefore, that the merger decision be made by a majority of all independent directors, so long as the number of independent directors is at least

277 See Alford, 358 S.E.2d at 328 (recognizing problems that arise from the structural bias inherent in the use of board-appointed special litigation committees but, nevertheless, permitting committee to decide on whether derivative action should proceed). In Miller v. Register \& Tribune Syndicate, Inc., 336 N.W.2d 709 (Iowa 1983), decided before Aronson, the Iowa Supreme Court held that a committee of directors whose members were nominated to the board after the commencement of a derivative action could not dismiss that suit. Id. at 718. The court reasoned that even if the new directors were independent by every other criterion, they could not be considered independent for purposes of judging the derivative action because the defendant/directors had appointed the committee. Thus, the court in Miller used its equity power to staff a committee. See id. It should be noted, however, that the court relied heavily on a draft of the American Law Institute's Corporate Governance Project that precluded defendant/directors from selecting a committee from among their fellow directors to judge a derivative action. See ALI, Principles of Corporate Governance and StructURE: Restatement and RECOMMENDATIONS $\S 7.03(\mathrm{e})$-(f) (Tent. Draft No. 1, 1982). The ALI since has retreated from its position. The current ALI draft permits directors who are defendants in a derivative suit to select the special litigation committee members. ALI DrafT No. 6, $\S 7.06(\mathrm{~b})$. The Comment to $\S 7.06(\mathrm{~b})$, however, states that the involvement of the defendants in the selection of the committee is a significant factor under $\S 7.10$ (b) for the court's consideration in determining if the committee is independent and, thus, if the lawsuit should be terminated on the committee's recommendation. Id. at 99; see also DeMott, The Corporate Fox and the Shareholders' Hen House, 65 N.C.L. REv. 569, 573 (1987) (arguing that the Miller court intended its restrictions on staffing a special litigation committee to be applicable only in demand-excused situations).

${ }^{278}$ See, e.g., Rosengarten, 613 F. Supp. at 1499 (decided after Aronson but ignoring that case's definition of when plaintiffs are in a demand-excused situation, thus qualifying for the Zapata test; instead, court proceeded to the Zapata standards in a demand-required situation); Alford, 358 S.E.2d at 327 (deciding to use Zapata in both demand-required and demand-excused situations, contrary to the holding in Aronson); cf. Miller, 336 N.W.2d at 712 (decided before Aronson, but refusing, on structural bias grounds, to allow, as does Aronson, defendant/directors to staff special litigation committee). For a discussion of the Zapata test, see infra notes 309-10 and accompanying text.

279 Delaware allows most board decisions to be delegated to a committee designated by the board of directors. Del. CoDE ANN. tit. 8, § 141(c) (1983 \& Supp. 1986). No committee, however, has the authority to effectuate certain transactions, one of which is adopting an agreement of merger. See id.; see also RMBCA, supra note 3, $\S 8.25$ (e) (imposing eight categories of limitations on powers of committees, including power to approve any action that requires shareholder approval). 
three. ${ }^{280}$ Moreover, involving all of the independent directors prevents management from choosing a sympathetic committee from among the independent directors.

Second, our proposal defines "independence"281 by reference to a familial or monetary relationship. Our definition reflects not only much of the current case law, ${ }^{282}$ but also reflects our confidence that the structural bias theory is unproven. Moreover, even if structural bias exists, it is more likely to affect directors who judge the potential liability of their fellow directors in derivative actions. In a merger, on the other hand, the independent directors would not be accusing their fellow directors of any wrongdoing but instead would be denying them the opportunity to engage in self-dealing. ${ }^{283}$ In discussing structural bias, one noted article on derivative actions agrees that derivative actions are

${ }^{280}$ We choose the minimum of three directors because of the great importance of merger decisions. See supra note 279 (discussing statutory prohibition of delegating merger decisions to board committees).

${ }^{281}$ See supra note 226 (indicating that this Article uses the term "independence" to denote both disinterest and independence).

${ }^{282}$ Much of this case law, however, has been criticized. See supra note 275 (delineating criticisms that the Aronson definition of independence is too broad); supra note 269 (setting forth ALI's rejection of Genzer's and General Tire's definitions of independence). The ALI has also defined an "interested director" to be one with an economic or familial relationship with, or subject to a controlling influence by, a party to the transaction. See ALI, Principles of Corporate Governance: Analysis AND Recommendations §1.18(a)(2) (Tent. Draft No. 5, 1986) [hereinafter ALI DRAFT No. 5]. For purposes of defining "independence" for a special litigation committee, the ALI requires that the committee both not be interested, as defined in $\S 1.18$, and as a group be "capable of informed and objective judgment under the circumstances." ALI DRAFT No. 6 , supra note $269, \S 7.10(\mathrm{a})$. The Comment to $\S 7.10$ (a) explains that this latter requirement has two components:

First, it requires that the committee have a minimal level of sophistication with respect to the transaction at issue. The absence of a disabling conflict of interest alone is insufficient; some affirmative capacity to judge the issues in dispute is necessary. Second, although the definition of "interested" looks only to economic and familial associations, the requirement of a capacity for "objective judgment" invites the court to look to other relationships that may also bias the inquiry. For example, a director who was the close personal friend and next door neighbor of the defendant would lack this capacity and should not serve on the committee.

Id. § 7.10(a) Comment e.

${ }^{283}$ The ALI would apparently agree with this distinction, given that it generally defines an "interested director" to be one with an economic or familial association, see ALI DRAFT No. 5, supra note $282, \S 1.18$, but then adds additional requirements for a director to be deemed independent for derivative action purposes, see supra note 282 . Note, however, that some courts believe that structural bias affects directors even outside the derivative action setting. Thus, in the tender offer area, some courts believe that independent directors' decisions do not warrant any special presumption of independence. See supra notes 120-254 (discussing different judicial views on structural bias in corporate control transactions). 
distinguishable from all other transactions:

At first glance, this vulnerability of board members might seem to apply equally to all board decisions, and therefore not distinguish the special case of a decision not to sue. But shades of difference exist, and this process . . . may cause even the outside director to perceive his role, once litigation is commenced, as that of a buffer by which to shelter and protect management from hostile and litigious stockholders. ... As a result, an outside director independent enough to oppose the chief executive officer with respect to a proposed transaction that he thinks is unfair or unwise may still be unable to tell the same officer that he thinks a suit against him has sufficient merit to proceed. The latter vote would be a far more personal and stigmatizing form of opposition. In short, prospective rejections can be diplomatic and couched in terms of the appearances of impropriety, but a refusal to protect one's peers once events have transpired is seen as disloyal treachery. ${ }^{284}$

Under our proposal, the Aronson criteria of independence and disinterest would disqualify any director who could gain or lose financially from the merger decision or who is related to an officer or director with such a financial interest. The proposal does not permit inside directors to qualify as independent because at a minimum, they may lose their positions as corporate officers. ${ }^{285}$ Other directors could, of course, fail to meet the rule's definition of independence. Obviously, in a merger, all directors could lose their board positions; our proposal thus disqualifies an outside director only if her financial interest in the merger is something more than the loss of the directorship. Similarly, if outside directors own shares of the target corporation, any proportional consideration they receive for those shares in a merger would not con-

284 Coffee \& Schwartz, The Survival of the Derivative Suit: An Evaluation and a Proposal for Legislative Reform, 81 CoLUM. L. REv. 261, 283 (1981) (footnotes omitted); see also Greene \& Junewicz, A Reappraisal of Current Regulation of Mergers and Acquisitions, 132 U. PA. L. REV. 647, 715 n.332 (1984) (stating that although courts may not review directors' decisions in other transactions, they are more willing to review directors' decisions in derivative actions).

${ }^{285}$ Inside directors may also receive incentives from the bidder, such as management contracts. Moreover, they may also have golden parachute agreements, which are agreements that frequently provide "substantial bonuses and other benefits for managers and certain directors upon a change in control of a company." Revlon, Inc. v. MacAndrews \& Forbes Holdings, 506 A.2d 173, 178 n.5 (Del. 1986); see also Siegel, supra note 27, at 378 n.4. 
stitute a disqualifying financial interest. ${ }^{288}$ Our proposal also disqualifies outside directors who have a family relationship either to one of the directors who is not independent or to a corporate officer. ${ }^{287}$

\section{Burden of Proving Independence}

Once director independence is defined, the next question is the appropriate allocation of the burden of proof. Again, the structural bias theory has affected how courts allocate the burden of proving director independence, with courts that are strong advocates of the theory imposing this burden on the directors. In some derivative action cases, including Aronson, courts have presumed director independence, ${ }^{288}$ while in others, courts have placed this burden of proof upon direc-

286 The Delaware Supreme Court has held that the directors will not be deemed interested if the benefit they receive in selling or exchanging their shares is conferred on all shareholders equally. See Unocal Corp. v. Mesa Petroleum Co., 493 A.2d 946, 957 59 (Del. 1985); accord Pogostin v. Rice, 480 A.2d 619, 625 (Del. 1984); Aronson, 473 A.2d at 812 .

287 We have extended the disqualification requirements to cover family ties to a corporate officer, as well as ties to an interested director, because we feel that the same conflict of interest arises in both relationships. Cf. ALI DRAFT No. 5, supra note 282, $\S 1.18$ (defining "interested" as one with a "financial or familial relationship with, or is subject to a controlling influence by, a party to the transaction, that . . . is sufficiently substantial that it would reasonably be expected to affect [one's] judgment with respect to the transaction in a manner adverse to the corporation").

${ }^{288}$ See Aronson, 473 A.2d at 814 (requiring shareholders to show facts that create reasonable doubt that directors are disinterested and independent). Some courts also cite Auerbach v. Bennett, 47 N.Y.2d 619, 631-32, 393 N.E.2d 994, 1001, 419 N.Y.S.2d 920,927 (1979), for the proposition that the court presumed that those directors not involved in the challenged transactions were independent and disinterested. See, e.g., Crouse-Hinds Co. v. InterNorth, Inc., 634 F.2d 690, 702-04 (court cited Auerbach for granting presumption of independence to directors); Genzer v. Cunningham, 498 F. Supp. 682, 688 (E.D. Mich. 1980) (electing to "follow the lead of the New York courts" in applying business judgment rule when "there is no allegation of personal gain by the directors"); Zapata Corp. v. Maldonado, 430 A.2d 779, 788 (Del. 1981) (interpreting Auerbach as placing this burden on plaintiff); Alford v. Shaw, 349 S.E.2d 41, 49-50 (N.C. 1986) (interpreting Auerbach as requiring plaintiff to rebut presumption of director's independence), rev'd on other grounds, 358 S.E.2d 323 (N.C. 1987). One noted expert on derivative actions argues that these courts have misread Auerbach. See DeMott, supra note 277, at 574 n.35. At least one court agrees with DeMott's reading of Auerbach. See Hasan v. CleveTrust Realty Investors, 729 F.2d 372, 378 (6th Cir. 1984) (holding that Auerbach requires the committee members to prove their independence). The source of the confusion on the proper reading of Auerbach is that the court in Auerbach, without allocating this burden to the defendants, nevertheless examined proof they submitted regarding their independence. Auerbach, 47 N.Y.2d at $631-33,393$ N.E.2d at 1001,419 N.Y.S.2d at $926-28$. The court then dealt summarily with the issue of their independence because all members of the committee had no affiliation with the corporation before joining the board and had joined the board after the questionable transaction had occurred. See id. Thus, the court found no triable issue as to the independence and disinterestedness of any of these committee members. 
tors. ${ }^{289}$ In litigation involving tender offer defensive tactics, the Delaware courts have presumed that outside directors were independent and, thus, their decisions were to be accorded great deference. ${ }^{290}$ The Second ${ }^{281}$ and Seventh ${ }^{282}$ Circuit Courts of Appeals, however, have not found the outside directors' decisions in the tender offering context deserving of any special treatment.

${ }^{289}$ See Rosengarten v. Buckley, 613 F. Supp. 1493, 1500 (D. Md. 1985) (requiring corporation to demonstrate independence of special litigation committee); Zapata, 430 A.2d at 788 (requiring special litigation committee to prove independence in context of demand-excused derivative action); $c f$. ALI DRAFT No. 6, supra note 269, $\S 7.11$ (b) (setting forth requirement that corporation has burden of demonstrating its qualifications).

In Zapata, the Delaware Supreme Court considered the directors' independence in the context of a demand-excused derivative action. See supra note 261 (discussing demand requirement for derivative actions). Although the Zapata court did not define independence, it required the directors to bear the burden of proving their independence. See Zapata, 430 A.2d at 788. The court in Zapata made clear its concern that structural bias would consciously or subconsciously taint the directors' independence. See id. at 787. Although the court did not focus on this issue, it should be noted that if the directors could prove their independence and disinterest, the plaintiff would not be in a demand-excused situation, and the principles enunciated by the Zapata court would not apply in a Delaware court.

The Aronson standards, delineated after Zapata, are not a rejection of the Zapata criteria even though Aronson's criteria, allocation of the burden of proof, and views on structural bias differ from those delineated in Zapata. But see infra note 312 (discussing how Aronson has made Zapata almost obsolete in Delaware). The two cases can be reconciled on the ground that the Delaware Supreme Court believed that the more stringent Zapata standards are appropriate in the context of a demand-excused derivative action. See Zapata, 430 A.2d at 787.

${ }^{280}$ See, e.g., Panter v. Marshall Field \& Co., 646 F.2d 271, 294 (7th Cir.) (applying Delaware law and stating that presumption of good faith is heightened when a majority of board consists of outside directors), cert. denied, 454 U.S. 1092 (1981); Polk v. Good, 507 A.2d 531, 537 (Del. 1986) ("[T] tors on the Texaco board, coupled with the advice rendered by the investment banker and legal counsel, constitute a prima facie showing of good faith and reasonable investigation."); Moran v. Household Int'l, Inc., 500 A.2d 1346, 1356 (Del. 1985) (noting that directors' proof is enhanced when majority of board consists of outside directors); Unocal, $493 \Lambda .2 \mathrm{~d}$ at 955 (same).

${ }^{201}$ See Hanson Trust PLC v. ML SCM Acquisition, Inc., 781 F.2d 264, 274 (2d Cir. 1986) (outside directors' decision not entitled to any presumption of propriety). In Norlin Corp. v. Rooney, Pace, Inc., 744 F.2d 255 (2d Cir. 1984), where the board, consisting of 10 directors, 7 of whom were outside directors, approved defensive tactics. See id. at 259-60. The court found "a collective conflict of interest underlying the board's action" that made the business judgment rule's presumption inapplicable. Id. at $266 \mathrm{n} .12$. The court's reasoning as to why the outside directors had a conflict of interest is murky. See Truesdell, Does Norlin Corp. v. Rooney, Pace, Inc. Preserve for Shareholders Control of a Corporation's "Ultimate Destiny"?, 20 Colum. J.L. \& Soc. Probs. 325, 343-51 (1986) (discussing the treatment of outside directors in Norlin and the fairness of defensive transactions).

${ }^{292}$ See Dynamics Corp. of Am. v. CTS Corp., 794 F.2d 250, 256 (7th Cir. 1986) (noting that presumption of independence does not exist even for outside directors because they are concerned about being fired if they displease the controlling shareholder), rev'd on other grounds, 107 S. C. 1637 (1987). 
While our proposal tracks Aronson's standards for defining independence as well as its views on structural bias, we depart from Aronson and the Delaware tender offer cases on the issue of allocating the burden of proof. Unlike Aronson, our proposal requires the directors to prove their independence. As the facts relating to these disqualifications are readily within the directors' reach, and often are unavailable to plaintiffs without extensive discovery, ${ }^{293}$ we believe that the directors should have this burden. Moreover, as the directors' independence is the pivotal consideration in the first part of our proposal, any substantial doubt with respect to independence should be resolved against them.

\section{Defining Due Gare}

Independent directors must, of course, select appropriate procedures and execute them in good faith to qualify their decisions for protection under the business judgment rule. In Smith $v$. Van Gorkom, ${ }^{284}$ the Delaware Supreme Court held that the directors violated their duty of care because they were grossly negligent in reaching their decision to approve a merger that had been recommended by Mr. Van Gorkom, the corporation's Chairman and Chief Executive Officer. ${ }^{285}$ The court gave the following summary of the reasons underlying its holding:

The directors (1) did not adequately inform themselves as to Van Gorkom's role in forcing the "sale" of the Company and in establishing the per share purchase price; (2) were uninformed as to the intrinsic value of the Company; and (3) given these circumstances, were, at a minimum, grossly negligent in approving the "sale" of the Company upon two hours' consideration, without prior notice, and without the exigency of a crisis or emergency. ${ }^{286}$

The court further disapproved of the directors' total reliance on Van Gorkom's recommendation and pointed out that their obligation was to consider seriously information reasonably attainable. ${ }^{287}$ Other

${ }^{283}$ Aronson has been criticized for requiring plaintiffs to allege facts describing the grounds for discrediting a director's independence. One critic notes that these facts are not within a plaintiff's grasp until extensive discovery has occurred. Emerson, Aronson and Its Progeny: Limiting Derivative Actions Through Demand Requirements, 19 J. Marshall L. Rev. 571, 600-01 \& n.219 (1986).

294488 A.2d 858 (Del. 1985).

${ }^{295}$ For an analysis of Van Gorkom, see Fischel, supra note 29, at 1445-47; Manning, supra note 61 , at 1-6.

${ }_{296}$ Van Gorkom, 488 A.2d at 874.

${ }^{207}$ Id. at 874-75; see also Weinberger, $457 \mathrm{~A} .2 \mathrm{~d}$ at 711-12 (reviewing the board's 
courts, in examining the directors' duty of care, have been concerned particularly with whether the directors had obtained independent, carefully-prepared advice on the critical elements necessary to make an informed decision. ${ }^{208}$

\section{Burden of Proving Due Care}

In reviewing tender offer defensive tactics, the Delaware courts have placed the initial burden on the directors to prove the reasonableness of their actions. ${ }^{289}$ Outside of the tender offer area, however, the courts apply the business judgment rule ${ }^{300}$ unless the court identifies a conflict of interest. ${ }^{301}$ Other courts, while sometimes discounting the importance of outside directors, nevertheless require plaintiffs to prove that the directors breached their fiduciary duty of care in deciding to implement a defensive tactic. ${ }^{302}$ Courts reviewing the procedures used by independent directors in the derivative action area, however, uniformly allocate this burden to the special litigation committee. ${ }^{303}$

procedure to determine whether the merger decision meets test of fairness to the minority shareholders); Manning, supra note 61, at 8-14 (providing list of statements in Van Gorkom that identify those steps necessary for board to establish due care).

${ }^{288}$ See Hanson Trust PLG v. ML SCM Acquisition, Inc., 781 F.2d 264, 276 (2d Cir. 1986) ("proper exercise of due care by a director in informing himself of material information and in overseeing the outside advice on which he might appropriately rely is ... a pre-condition to performing his ultimate duty of acting in good faith"); Samjens Partners I v. Burlington Indus., Inc., 663 F. Supp. 614, 625 (S.D.N.Y. 1987) (finding relevant to determination that board's decisions were justifiable and made in good faith fact that board reached decision after consultation with financial and legal advisors); see also Coffee \& Schwartz, supra note 284 at 323 (requiring independent counsel to advise the board on merits of derivative action); Kahn v. United States Sugar Corp., No. 7313, slip. op. at 7-9, 31-33 (Del. Ch. Dec. 10, 1985) (finding directors' use of independent investment banking firms to value the company insufficient to ward off liability for breach of fiduciary duty).

${ }^{299}$ See Unocal Corp. v. Mesa Petroleum Co., 493 A.2d 946, 955-56 (Del. 1985); see also Samjens, 663 F. Supp. at 623 (placing the burden on the board to show good faith and reasonable investigation before the business judgment rule applies); supra notes 48-49 and accompanying text (setting forth Unocal requirements).

${ }^{300}$ See supra note 28 and accompanying text (allocating the burden of proof to plaintiffs under business judgment rule).

so1 See, e.g., Weinberger, 457 A.2d at 703 (after plaintiff demonstrated defendants' conflict of interest in freeze-out merger, court allocated burden of proof to defendants); Sinclair Oil Corp. v. Levien, 280 A.2d 717, 722 (Del. 1971) (delineating test to determine if self-interest exists, and if one does, parent has burden to prove fairness of transaction with its subsidiary); supra note 36 and accompanying text (discussing burden on defendants to prove fairness if they have a conflict of interest).

${ }^{302}$ See, e.g., Hanson, 781 F.2d at 273 (although disregarding input of outside directors, court allocated initial burden of proof to the plaintiff; the court noted that the plaintiff would fare better in Delaware under Unocal standards).

${ }^{303}$ See, e.g., Joy v. North, 692 F.2d 880, 891 (2d Cir. 1982), cert. denied sub nom. Citytrust v. Joy, 460 U.S. 1051 (1983); Rosengarten v. Buckley, 613 F. Supp. 1493, 1500 (D. Md. 1985); Abella v. Universal Leaf Tobacco Co., Inc., 546 F. Supp. 
Our proposal follows the business judgment rule by allocating to plaintiffs the burden of proving the insufficiency of the independent directors' procedures. Under the business judgment rule, it is presumed that the directors have fulfilled their duties of care and loyalty. Some courts do not accord directors this presumption because of the courts' concern that the directors have made a decision in their own self-interest. ${ }^{304}$ If the directors can prove their independence, as our proposal requires, then, by definition, they do not have any disabling conflict of interest. In that event, the presumption of due care should lie with them.

\section{Scope of Judicial Review}

Unless a plaintiff proves that the directors failed to fulfill either their fiduciary duties of care or loyalty, courts usually apply the business judgment rule, which shields the merits of the directors' decision from judicial review. ${ }^{305}$ The court in Unocal departed from the traditional standard by requiring the directors to meet certain standards before their decision would be protected by the business rule. ${ }^{306}$ In contrast, in Zapata Corp. v. Maldonado, ${ }^{307}$ the Delaware Supreme Court's concerns about structural bias in a demand-excused derivative action caused it to depart radically from the business judgment rule. ${ }^{308}$ The court in Zapata reserved not only the right to review both the directors' reasoning and their ultimate decision ${ }^{309}$ but also the right to

795, 800 (E.D. Va. 1982); Auerbach v. Bennett, 47 N.Y.2d 619, 635-36, 393 N.E.2d 994, 1003, 419 N.Y.S.2d 920, 929-30; ALI DRAFT No. 6, supra note 269, § 7.11(b). Cases following Zapata seem to demand a detailed report from the directors of their procedures and findings. See, e.g., Hasan v. Glevetrust Realty Investors, 729 F.2d 372, 379 (6th Cir. 1984) (finding that the board's report failed to demonstrate the procedural adequacy of its investigation); Rosengarten, 613 F. Supp. at 1501-03 (finding it important that committee prepared lengthy report); $c f$. ALI DRAFT No. 6, supra note $269, \S 7.08$ (b) (report must set forth "adequately particularized and supported findings").

304 See discussion supra note 36 and accompanying text (discussing application of fairness test in conflict of interest transactions). Thus, giving the burden of proof to the independent directors would denote that they are not truly independent. rule).

${ }^{305}$ See supra notes 25-26 and accompanying text (discussing business judgment

${ }^{306}$ See supra notes $47-49$ and accompanying text (discussing Unocal test).

307430 A.2d 779 (Del. 1981).

sos See id. at 787. Contra Auerbach v. Bennett 47 N.Y.2d 619, 633-34, 393 N.E.2d 994, 1002, 419 N.Y.S.2d 920, 928 (1979) (holding that business judgment rule applies where some directors are charged with wrongdoing, so long as the remaining directors making the decision are disinterested and independent).

${ }^{309}$ See Zapata, 430 A.2d at 788 . These requirements are, however, subject to debate. At one point, the court required the corporation to prove the directors' independence, good faith, and reasonable investigation. See id. at 788. At two other points, however, the court required the trial court to determine whether the special litigation 
exercise independent judgment as to whether the derivative suit should be dismissed. ${ }^{\mathbf{3 1 0}}$

Zapata and its progeny, however, should be narrowly confined to their facts. Whatever may be the courts' ability to exercise business judgment regarding the continuation of derivative actions, ${ }^{311}$ they clearly lack any expertise to make merger decisions. The Delaware Supreme Court should agree with this distinction. ${ }^{312}$ That court's en-

committee had "reasonable bases for its conclusions." Id. at 788-89. Thus, it is unclear if Zapata requires both a reasonable investigation and reasonable bases for the committee's conclusions. At least three courts have required both a reasonable investigation and reasonable bases. See Rosengarten v. Buckley, 613 F. Supp. 1493, 1503 (D. Md. 1985); Abella v. Universal Leaf Tobacco Co., 546 F. Supp. 795, 800 (E.D. Va. 1982); Kaplan v. Wyatt, 499 A.2d 1184, 1188 (Del. 1985). Other courts speak simply in terms of a reasonable investigation. See, e.g., Auerbach, 47 N.Y.2d at 634, 393 N.E.2d at 1002-03, 419 N.Y.S.2d at 929 (rejecting judicial inquiry into substantive business judgment and requiring only a reasonable investigation).

${ }^{310}$ See Zapata, 430 A.2d at 789. The Delaware Supreme Court has reaffirmed that Zapata gives the courts discretionary power to use their own business judgment. See Kaplan, 499 A.2d at 1188. Some courts, however, have interpreted the Zapata test as routinely requiring this second level of judicial review. See Joy v. North, 692 F.2d 880, 891 (2d Cir. 1982), cert. denied sub nom. Citytrust v. Joy, 460 U.S. 1051 (1983); Rosengarten, 613 F. Supp. at 1504; Abella, 546 F. Supp. at 801.

The court in Zapata stated that even if a court were satisfied with its findings about the corporation's procedures and reasoning, the court may still use its own business judgment as to whether the derivative action should be terminated; in using its own business judgment, the court may consider, in addition to whether the suit is in the corporation's best interest, matters of law and public policy. Zapata, $430 \mathrm{~A} .2 \mathrm{~d}$ at 788 . Zapata's stringent tests were motivated by the court's fear that directors, in a demandexcused situation, could not effectively judge their fellow directors' actions. See id. at 787-89. Note that some courts are applying the Zapata principles in both demandrequired and demand-excused situations, although the Delaware court limited these principles to the demand-excused situation. See supra note 278.

Critics of Zapata primarily argue that a court should not substitute its business judgment for that of the directors. See Note, Special Litigation Committees and the Judicial Business Judgment Morass-Joy v. North, 32 DE Paul L. REv. 933, 953-58 (1983). But see infra note 311 (arguing courts are equipped to exercise business judgment in this context). For an analysis of Zapata, see Block \& Prussin, Termination of Derivative Suits Against Directors on Business Judgment Grounds: From Zapata to Aronson, 39 Bus. LAw. 1503 (1984); Veasey, Seeking a Safe Harbor from Judicial Scrutiny of Directors' Business Decisions-An Analytic Framework for Litigation Strategy and Counseling Directors, 37 Bus. LAw. 1247, 1262-74 (1982). Moreover, although Zapata clearly has two steps for reviewing the directors' decision, one commentator has argued that there is no difference between the two steps as applied because a court has never upheld the directors' decision in step one but then rejected their decision in step two. See Cox \& Munsinger, supra note 247, at 126-27.

${ }^{311}$ The argument concerning the court's using its business judgment has been justified as within the court's expertise because the decision is comparable to a summary judgment motion. See Note, Dismissal of a Derivative Suit: The Zapata Test Can Work, 8 AM. J. Trial. ADvoc. 485, 491 (1985) (arguing that courts are qualified to exercise judgment as to whether a lawsuit should proceed).

312 By making the criteria in Aronson for getting to a demand-excused situation so difficult and by limiting Zapata to only demand-excused situations, the Delaware Supreme Court has made Zapata almost obsolete. This may indicate that the court is 
dorsement of independent directors in the tender offer area ${ }^{313}$ conveys its view that directors, not judges, must make these business decisions. Once the directors have established their independence-thus obviating a duty of loyalty claim-and their procedures are not sufficiently challenged-thus obviating a duty of care claim-we see no reason to subject the decision itself to any level of judicial review. The decision is then a classic business decision and should be protected by the business judgment rule.

\section{Evaluation of the Independent Director Requirement}

We believe that the use of independent directors to make merger decisions is not the perfect solution to the problem of the inside directors' unavoidable conflict of interest, but rather that it is the optimal solution. ${ }^{314}$ While proponents of a structural bias theory and those doubting the efficacy of independent directors may be skeptical of the performance of such directors, surely independent directors are a better safeguard of the shareholders' interests than are directors who are not independent. This safeguard is particularly important in merger rejection cases, where the structural monitor is inoperative. By requiring directors to prove their independence, our proposal ensures that potential loyalty issues are minimized. The proposal implicitly recognizes that existing judicial doctrines are adequate to monitor the directors' satisfaction of their duty of care. ${ }^{315}$

We believe the major problem with our proposal does not relate to the structural bias theory, but rather to the fact that it disqualifies in-

unhappy with the active role it created for itself in Zapata. Other courts following Zapata, however, have not followed Aronson and thus continue the type of judicial review delineated in Zapata. See supra note 278 (discussing cases that utilize Zapata test for both demand-required and demand-excused cases).

${ }^{313}$ See supra note 120 (discussing corporate control cases that endorse corporation's use of outside directors).

s14 The conclusion that use of only independent directors is the optimal solution is reflected in the fact that they currently serve a variety of purposes. Outside or independent directors serve numerous functions in a corporation, ranging from ensuring compliance with the corporate statutes to monitoring management's performance. See generally Brudney, supra note 247.

${ }_{315}$ See, e.g., Van Gorkom, 488 A.2d at 873-81 (analyzing board's procedure to see if directors met their duty of care). Zapata held that independent directors should produce a report delineating their procedures and reasoning. Zapata, $430 \mathrm{~A} .2 \mathrm{~d}$ at 788 . While we impose no such requirement, independent directors would be wise to create a record of their decisionmaking processes because cases like Van Gorkom demonstrate that the court will scrutinize the steps taken by directors before reaching their decision. See Van Gorkom, 488 A.2d at 873; Manning, supra note 61, at 6 (suggesting that directors would be well-advised to be thoroughly prepared before voting on an issue involving shareholders' stock ownership); supra notes 296-98 and accompanying text (discussing what constitutes due care). 
side directors, because they are not independent, from participating in the consideration, negotiation, and vote on a merger proposal. Our reasons for disqualifying these directors from all aspects of the consideration of a merger offer is due both to their inherent conflict of interest, as well as to the apparent ease with which they could "poison the well." Information from the inside directors concerning either the dire or beneficial consequences they perceive arising from the proposed merger, coupled with an active role in the merger negotiations, might strongly predispose the independent directors to simply follow management's recommendation. ${ }^{\text {316 }}$

While the benefits of excluding the inside directors are clear, there is a concomitant problem arising from this exclusion: the independent directors lose the input of those directors who are most knowledgeable about the corporation. Without input from management, the independent directors might not have enough knowledge about the target's operations to assess accurately the costs and benefits of the proposed merger. ${ }^{317}$ The independent directors could, however, purchase much of the needed information from outside experts, and if outside experts were unable to supply the needed information, the independent directors could invite target managers to present their assessment of the merger proposal. In this event, the independent directors should consider management's analysis but recognize the bias that may pervade the presentation. The managers' presentation to the independent directors should be sufficiently contained so that these managers, serving as experts, do not indirectly secure a role in the negotiation process.

A second problem with the proposal concerns the desirability of relegating a decision as important as a merger to a potentially small number of directors. This concern is reflected in the corporate statutes, which permit most corporate decisions to be made by a committee of directors but require full board participation in a merger decision..$^{\mathbf{3 1 8}}$ Our proposal reflects our belief that a decision by independent directors, even if few in number, is better than a decision made by the entire board, including those directors who are not independent. Our prefer-

${ }^{316}$ Cf. Comment, A Procedural Treatment of Derivative Suit Dismissals by Minority Directors, 69 CALIF. L. REv. 885, 899 (1981) (discussing problem that while outside directors may not have enough information about the corporation to decide whether a derivative suit should proceed, corporate managers give the outside directors biased information).

${ }_{317}$ But see Samjens Partners I v. Burlington Indus., Inc., 663 F. Supp. 614, 62425 (S.D.N.Y. 1987) (concluding that board made up of majority of outside directors possessed adequate knowledge to negotiate for and approve a merger).

s18 See supra note 279 (corporate statutes do not confer authority on committees to make merger decisions). 
ence for the chosen solution reflects a special concern for shareholders' welfare in merger rejection cases, where the structural monitor is inoperative.

The possibility exists that a corporation will have fewer than three directors that satisfy the independence standard. Traditionally, neither federal $^{319}$ nor state law has regulated the composition of corporate boards. ${ }^{320}$ This proposal continues that policy, yet joins the case law ${ }^{321}$ and initiatives from the SEG, ${ }^{322}$ the New York Stock Exchange, ${ }^{323}$ the American Bar Association, ${ }^{324}$ and the Business Roundtable ${ }^{325}$ that have underscored the benefits to corporations of having outside directors. ${ }^{326}$ By giving a significantly different burden to the corporation that does not have the requisite number of independent directors, the proposal will provide an incentive to corporations to establish independent boards.

Under our proposal, if three independent directors are unavailable, the target corporation will have the burden of proving the fairness $^{327}$ of its merger decision. The burden of proving fairness is borne

s19 But see Investment Company Act of 1940,15 U.S.C. $\$ 80 a-10(a)$ (1982) (requiring at least $40 \%$ of board members to be disinterested).

${ }_{320}$ See Karmel, The Independent Corporate Board: A Means to What End?, 52 Geo. Wash. L. ReV. 534, 544 (1984).

s21 See supra notes 120, 234 (discussing judicial encouragement to corporations to use outside or independent directors).

322 As early as 1940, the SEC recommended that corporations form committees of independent directors. See In re McKesson \& Robbins, Inc., Exchange Act Release No. 2707 (Accounting Series Release No. 19), [1937-1982 Transfer Binder] Fed. Sec. L. Rep. (CCH) If 72,020, at 62,104, 62,108 (Dec. 5, 1940). In 1972, the SEC stated that it endorsed audit committees composed of outside directors. Standing Audit Committees Composed of Outside Directors, Securities Act Release No. 7091 (Accounting Series Release No. 123), [1937-1982 Transfer Binder] Fed. Sec. L. Rep. (CCH) If 72, 145, at 62,300 (Mar. 23, 1972).

${ }_{323}$ In 1977, the New York Stock Exchange strongly recommended that each listed company form an independent audit committee. See 42 Fed. Reg. 8737 (1977). The SEC approved this rule and required all listed domestic companies to comply. 42 Fed. Reg. 14,793 (1977).

524 The American Bar Association issued a guidebook recommending that nonmanagement directors constitute a majority of the board. See Committee on Corporate Laws, ABA, The Corporate Director's Guidebook, 32 Bus. LAw. 5, 33 (1976).

${ }_{325}$ The Business Roundtable issued a report recommending that outside directors play a substantial role in the board's decisionmaking process. THE BUSINESS RounDTable, The Role and Composition of the BoArd of Directors of the LaRge Publicly OWNEd CoRPoRATION 19-21 (1978).

${ }^{828}$ A recent study indicates that $53.2 \%$ of Fortune 1000 chairpersons responding to a survey believe the law should require the large, publicly held companies to have a majority of outside directors. See HEIDRICK \& STRugGles, supra note 251, at 1.

\$27 What constitutes fairness has not been defined by statute and has been subject to various judicial interpretations. Some courts have required a defendant to prove a proper corporate purpose under a fairness test. See, e.g., Treadway Cos., Inc. v. Care Corp., 638 F.2d 357, 382 (2d Cir. 1980). Other courts have required the decision to be primarily in the corporate interest in order to be fair. See, e.g., Bennett v. Propp, 41 
by directors in any conflict of interest transaction and is a substantially more difficult burden than that shouldered by independent directors under our proposal. The proposed rule, by requiring the corporation to prove the fairness of merger decisions made by directors who are not independent, is an acknowledgement that such directors have a potential conflict of interest. The explicit recognition of this conflict is a significant departure from current merger statutes and some case law and should better protect the operation of the structural and market monitors.

\section{Comments on Part Two: The Permissible Boundaries of Merger Covenants}

\section{General Comments on Part Two}

The proposed rule's independent director requirement is designed to ensure, to the fullest extent possible, the loyalty of target directors in rejecting or approving a merger proposal. The balance of the proposed rule attempts to make certain that even independent directors acting with due care do not, in approving a merger proposal, take actions that impede the structural and market monitors of board decisions. The proposal recognizes that shareholders and directors each have a legitimate and well-defined role in a merger transaction. Directors must negotiate and approve all of the varying complexities of a merger; the shareholders must approve only the essential terms of the merger agreement. ${ }^{328}$ The proposal thus adopts the Galifornia statutory model ${ }^{\mathbf{3 2 \theta}}$ and provides that target directors can enter into binding covenants to govern their conduct pending the required shareholder vote on the essential terms of the merger agreement. Unlike the California model, however, essential merger terms under the proposed rule include lock-ups and cancellation fees. ${ }^{330}$

Del. Ch. 14, 22, 187 A.2d 405, 409 (Del. 1962). Still other courts have required the defendant to demonstrate a compelling business purpose to prove the transaction was fair. See, e.g., Klaus v. Hi-Shear Corp., 528 F.2d 225, 233-34 (9th Cir. 1975); see also supra note 36 (discussing fairness).

${ }_{328}$ The difficulty of accurately presenting and explaining even the basic terms of the merger to the shareholders suggests the difficulty of holding a meaningful vote on nonessential matters. See, e.g., Repairman's Serv. Corp. v. National Intergroup, No. 7811 , slip op. at 2 (Del. Ch. March 15, 1985) (preliminary injunction sought to enjoin merger transaction on grounds of materially misleading statement in proxy solicitation); cf. Freund \& Greene, supra note 224, at 1488-95, 1508 (suggesting that the thencurrent S-14 disclosure statement for exchange mergers was overwhelming to shareholders and needed significant streamlining).

s2s See supra notes 161-62 and accompanying text.

sso The California Code does not define "principal terms of a reorganization," see 
The basic premise underlying Part Two of the proposal is that target directors should have maximum flexibility in negotiating a merger agreement so long as their actions do not unduly impede the shareholders' structural role and the market of competing bidders. By permitting the directors to agree to some exclusive merger covenants but subjecting lock-ups and cancellation fees to a shareholder vote, the proposed rule in effect steers a middle course between models advocated by staunch supporters of the anti-auction theory and those advocating unrestrained competition for the target. ${ }^{331}$ The proposal does not, however, attempt to resolve the issue of which theory better enhances shareholder or societal wealth. Instead, the proposal is premised upon the belief that maximum shareholder wealth will result if the shareholders, aided by information provided by the marketplace, can effectively monitor business decisions made with due care by independent directors. ${ }^{\mathbf{3 2}}$

Cal. Corp. Code $§ 1201$ (a) (West 1977 \& Supp. 1987), and thus it does not explicitly exclude lock-ups or cancellation fees from the shareholder approval requirement. However, it appears to be a "common law" understanding that such exclusive merger provisions are not, under the current statute, principal terms of the merger which are subject to shareholder approval. See supra note 161 (discussing $§ 1201$ (a)); see also Buffalo Forge Co. v. Ogden Corp., 555 F. Supp. 892, 905 (W.D.N.Y.) (holding that, under New York law, a lock-up option was not part of the plan of merger and therefore was not subject to shareholder approval), affd, 717 F.2d 757 (2d Cir.), cert. denied, 464 U.S. 1018 (1983).

${ }^{331}$ See supra notes 193-203 and accompanying text (discussing the auction and anti-auction theories of wealth maximization).

ss2 The proposal necessarily contemplates a meaningful shareholder vote on the merger proposal. Some argue, however, that the voting rights of shareholders lack significance due to the shareholders' wide dispersal and general lack of interest in corporate affairs. See, e.g., Manning, The Shareholder's Approval Remedy: An Essay for Frank Coker, 72 YALE L.J. 223, 261 (1962) ("[S]hareholders as a lot have little or no real concern with . . . 'fundamental' transactions . . . . [They] always vote[] 'yes' on the proxy."). This theory is supported by the fact that shareholders routinely approve charter amendments providing for supermajority voting even though such provisions are rarely in their best interest. See Gilson, The Case Against Shark Repellent Amendments: Structural Limitations on the Enabling Concept, 34 STAN. L. REv. 775, 82227 (1982) [hereinafter Gilson III]; Lowenstein, supra note 21, at 331. This view is contradicted, however, by empirical data demonstrating that shareholdings, rather than being dispersed, are heavily concentrated in the hands of institutional and other sophisticated investors. See M. EISENBERG, supra note 30, at 43-51. Institutional investors utilize great scrutiny in reviewing proposed structural changes. They have in recent years increasingly voted against shark repellent charter amendments. See, e.g., Gilson III, supra, at 826 (discussing data demonstrating that shark repellent amendments generate "the second greatest incidence of antimanagement voting"). Furthermore, even shareholders with smaller holdings, who may generally support management proposals, will have a substantial and personal interest in casting a meaningful vote on a merger transaction. See M. EisENBERG, supra note 30, at $65 \mathrm{n} .1$ (citing a number of corporate proposals involving structural changes that were either withdrawn due to shareholder opposition or passed by only narrow margins); Lowenstein, supra note 21 , at 332 (It is unlikely shareholders would be apathetic in voting on a tender offer when "[ $t]$ here is immediacy and drama."); see also Clark, Vote Buying and Corporate Law, 29 CASE W. REs. L. REV. 776, 779-90 (1979) (discussing factors influencing shareholder in- 
Part Two of the proposal is thus designed to promote flexibility for directors to respond to individual situations while preserving the monitoring mechanisms.

\section{Reach of Part Two}

Part Two of the proposal regulates all negotiated acquisitions of a target. The proposal recognizes that mergers are but one of several related acquisition techniques. ${ }^{333}$ A regulation covering mergers alone would simply lead parties desiring to escape its constraints to consider alternatives such as friendly tender offers. ${ }^{\mathbf{3 4}}$ Therefore, Part Two of the proposal covers actions or agreements by target directors in connection with any acquisition attempt in which target management has acquiesced. ${ }^{335}$ Such acquisitions include negotiated tender

volvement); Easterbrook \& Fischel, Voting in Corporate Law, 26 J.L. \& ECoN. 395, 416 (1983) (possibility of large gains or losses in corporate control transactions may be sufficient to overcome shareholder apathy).

${ }^{333}$ See supra note 224.

ss4 Accord Gilson I, supra note 13, at 850 ("[T] tween different acquisition techniques, but between negotiated and hostile transactions."); cf. Leebron, supra note 1, at 199 ("[O]ne of the most important factors in bargaining is the strategic alternatives of the parties. Thus, the availability of a tender offer should have a substantial effect upon the bargaining in a merger. . . . If we choose not to regulate tender offers, then we are deciding not only how the gains are to be distributed in tender offers, . . . but also influencing how the gains will be allocated in negotiated mergers.").

${ }_{338}$ Part Two of the proposal, unlike Part One, covers any negotiated acquisition of the target including pure tender offers to the extent that target management desires to bargain with the bidder. It is possible that the "substance over form" considerations apply equally to the independent director requirement that, under Part One of our proposal, does not apply to tender offers that are not part of an overall acquisition agreement between the acquiring company and target directors. See supra note 224. It may in fact be the case that friendly tender offer proposals, which all directors could consider under the proposal, would be substituted for merger proposals, which only independent directors can consider. This change in form would occur, for example, if acquiring company directors felt that it was cheaper overall to provide incentives to interested target directors than to pay the price that may be demanded by whollyindependent negotiating groups. Also, as it may be difficult at the onset of negotiations to predict the eventual form of the acquisition, see Freund \& Easton, supra note 224, at 1680-81, the divergence in the independent director requirement could cause complex negotiating problems. On the other hand, it is equally difficult to predict whether a bidder's initial expression of interest may result in a friendly acquisition or a hostile tender offer. Requiring independent directors to evaluate friendly but not hostile tender offers would also cause serious complications unless there is a willingness to require that all tender offers be evaluated only by independent directors. While this latter solution may indeed be optimal, it runs against the strong tide of recent state legislative enactments designed to give target directors the statutory authority to impede hostile tender offers and to attempt to retain the independence of the target. State legislatures, prodded by local constituents, are unlikely to reverse this trend in the foreseeable future absent congressional intervention. See supra note 105 . We are reluctant, therefore, without additional input, to extend the independent director requirement to friendly 
offers $^{336}$ as well as mergers.

The proposal does not take a general position regarding the proper role of target management in responding to a hostile tender offer. ${ }^{\mathbf{3 3 7}}$ The proposal suggests limited regulation of the target board's responses to hostile offers only in situations in which the target board has elected to sell the target. Such regulation is necessary in these for-sale settings in order to preserve the role of the tender offer as an effective market monitor of the directors' decisions in negotiated acquisitions. ${ }^{338}$

\section{The Legal Status of Board-Approved Covenants Prior to the Shareholder Vote}

The proposal provides that, prior to the shareholder vote, target directors can, with specified exceptions, enter into legally-binding merger covenants. The proposal thus codifies the prevailing, though largely unsupported, judicial view that directors possess the power to enter into such covenants, leaving only basic contract questions at issue. ${ }^{339}$

It is clear that certain undertakings by the respective boards are essential to the completion of a merger transaction. A rule denying directors the power to enter into any merger covenants prior to the share-

tender offers as well as mergers unless the tender offer is part of an acquisition agreement. No similar constraints, however, suggest such a limitation with regard to the target directors' unilateral powers to grant lock-ups, cancellation fees, or exclusive access to nonpublic information to one bidder in the for-sale setting. Part Two of the proposal thus regulates these devices for both merger and pure tender offer acquisitions.

338 One study, analyzing data collected by the Office of the Chief Economist of the SEC, indicated that the vast majority of tender offers successfully concluded from 1981 through 1984 ultimately were negotiated transactions. See Oesterle, supra note 30, at 120 (citing R. Comment and G. Jarel, Two-Tier Tender Offers: The Imprisonment of the Free Riding Shareholder (Mar. 1, 1986) (unpublished manuscript)); see also Austin, Nigem \& Bernard, supra note 1, at 50 (of the 222 successful or partially successful tender offers completed in 1985 and 1986, 208 ultimately were negotiated transactions).

${ }^{337}$ The literature on this subject is voluminous. See supra note 70 . The outer parameters of the debate concerning the propriety of tender offer defensive tactics are perhaps best exemplified in a series of articles by Easterbrook and Fischel on the one hand and Martin Lipton on the other hand. See Easterbrook \& Fischel I, supra note 42; Easterbrook and Fischel II, supra note 70; Lipton, supra note 70; Lipton, Takeover Bids in the Target's Boardroom: An Update After One Year, 36 Bus. LAw. 1017 (1981); Lipton, Takeover Bids in the Target's Boardroom, 35 Bus. Law. 101 (1979). As Professor Lowenstein so aptly characterized this debate: "Lipton sees no problem in defensive tactics, while Easterbrook and Fischel see no problem except for defensive tactics." Lowenstein, supra note 21, at 251.

${ }_{338}$ See infra notes 354-61 and accompanying text.

s39 See, e.g., Texaco v. Pennzoil, 729 S.W.2d 768, 788-96 (Tex. Ct. App. 1987) (defendant Texaco in a tortious contract interference case unsuccessfully argued that target directors did not intend to enter into a binding contract with plaintiff); see also supra notes 137-39 and accompanying text. 
holder vote would be unwise. Such a rule would prohibit legal enforcement of even the housekeeping covenants. But for the recent surge in the use of exclusive merger covenants, it is unlikely that the directors' authority in this area would have been subject to serious challenge. The proposed rule eliminates the ambiguity inherent in current statutes, thus enabling the debate to center upon items of greater consequence.

\section{Best Efforts Covenants}

Under the proposal, corporate directors could agree to best efforts covenants that would, absent a change in circumstances such as a competing offer, bind the directors to perform dutifully the undertakings in the merger agreement and to recommend that the shareholders approve the merger. The proposal, however, requires the directors to provide shareholders with complete and fair disclosure of any competing offers and to make recommendations in light of all relevant facts known at the time of the shareholders' vote. ${ }^{340}$ The proposal codifies what is probably the prevailing judicial view of directors' common law fiduciary duty obligations $^{341}$ and what is certainly their duty of disclosure under the federal proxy rules. ${ }^{342}$ The proposal rejects contrary implications in the Crouse-Hinds cases. ${ }^{343}$

The fair disclosure and recommendation requirements contained in the proposal are essential to the effective operation of the structural and market monitors of board actions. The importance of the directors' disclosure and recommendation cannot be overstated. Target directors are in a unique position to provide information assessing the relative merits of acquisition proposals because they are generally privy to nonpublic information regarding the intrinsic value of the target. ${ }^{344}$ Moreover, target directors are obviously in a better position than are most of their shareholders to undertake the costly and complex process of evalu-

340 Given that most shareholders in public corporations vote through proxies, this requirement may force a second proxy solicitation process and a delay of the vote if new information becomes available after the initial solicitation. See, e.g., R-G Denver Ltd. v. First City Holdings, 789 F.2d 1469, 1475 (10th Cir. 1986) (board had an obligation to delay vote and resolicit proxies when the situation had changed because of competing offer).

s41 See supra notes $173-87$ and accompanying text.

342 SEC Rule 14a-9, 17 C.F.R. § 240.14a-9 (1987).

s4s Crouse-Hinds Co. v. Internorth, Inc., 634 F.2d 690 (2d Gir. 1980); Belden Corp. v. Internorth, Inc., 90 Ill. App. 3d 547, 413 N.E.2d 98 (1980); see supra notes 181-83 and accompanying text.

34 See Gilson I, supra note 13, at 865-67 (discussing information possessed by target managers as it relates to their evaluation of tender offers); $c f$. Booth, supra note 100 , at $633-38$ (discussing and refuting arguments that management buy outs should be prohibited because they constitute trading on inside information). 
ating the comparative worth of the target and the consideration offered by the various bidders. ${ }^{345}$ Few shareholders have sufficient economic incentive to personally undertake such an analysis, ${ }^{346}$ and even those who do may not wish to disseminate the information to other shareholders. ${ }^{347}$ Centralized production and dissemination of this information by the target board is not only the most efficient disclosure mechanism but also the only realistic one. This reasoning underlies the disclosure provisions of the federal securities laws ${ }^{348}$ and applies with equal force to the maintenance of the shareholders' structural role in the merger process and the monitoring role provided by competing bids. ${ }^{349}$

345 In a cash offer, the target shareholders must compare the offering price with the present market price of the target shares and any additional information which target management may provide regarding the future value of the target shares. In an exchange offer, additional information is necessary regarding the present and potential future value of the offeror's securities. In either event, the costs and resources necessary to produce this information dictate centralized production through target management. See Advisory Comm. on Corporate Disclosure to the Securities and Exchange Comm., 95Th Cong., 1st Sess., Report of the Advisory Comm. ON Corporate Disclosure to the Securities and Exchange Comm. 618, 625-640 (Comm. Print 1977) (paper entitled The Nature of Mandated Disclosure prepared by Professor W. Beaver) [hereinafter Beaver] (discussing rationales for disclosure regulations); see also Booth, Is There Any Valid Reason Why Target Managers Oppose Tender Offers?, 14 SEC. REG. L.J. 43, 56-57 (1986) (discussing why management is in best position to assist shareholders in evaluating "the merits of a deal"); Gilson I, supra note 13, at 865-67 (explaining the role of target management in providing shareholders with information).

${ }_{346}$ This presents the free rider problem. See supra note 23. See also Beaver, supra note 345 , at $626-628$ (discussing the free rider problem as it relates to mandated disclosure); Gilson I, supra note 13, at 867 (explaining how individual shareholders find costs of information to be very high). The free rider problem may in large part explain why shareholders generally approve management proposals. See supra note 332.

347 Institutional investors or other large shareholders may indeed have an economic incentive to evaluate merger proposals separately. Dissemination of this information to other shareholders, however, can involve the costly and somewhat ineffective mechanism of proxy solicitation. Large investors seldom have a sufficient incentive to engage in this undertaking, see supra note 23 , and thus the other shareholders are deprived of their analysis, see Beaver, supra note 345, at 629 (discussing the costs of disclosure). Moreover, target management will invariably engage in its own analysis of merger proposals. Efficiency concerns dictate that larger investors have access to this information.

${ }_{348}$ See Weiss, Disclosure and Corporate Accountability, 34 Bus. Law. 575, 579 80 \& n.12 (1979) (discussing the history of SEC disclosure negotiations); Weiss \& Schwartz, Using Disclosure to Activate the Board of Directors, 41 LaW \& CoNTEMP. PROBS., Summer 1977, at 63, 64-69 (same); see also Beaver, supra note 345, at 625640 (outlining arguments for disclosure regulation).

${ }_{349}$ The proposed rule does not regulate the directors' obligations under the initial merger agreement once the directors have concluded that a competing offer is advantageous and have decided to recommend that shareholders approve the competing offer. It is probably an empty and needlessly expensive gesture for the target board to continue to fulfill the housekeeping covenants and to submit the initial proposal to their share- 


\section{No-Shop Covenants}

The proposal allows target directors to negotiate enforceable noshop covenants subject to the target board's obligation to disclose competing bids and to make recommendations according to the relative merits of the offers. The proposal thus implicitly recognizes that it may be necessary for target directors to offer some incentives to an acquiring company to make the initial bid or to a competing bidder to enter the contest. $^{.50}$ The informational advantage and exclusive board access that could be gained from no-shop and related board performance promises supply such an incentive. ${ }^{\mathbf{3 5 1}}$

By preserving the ability of the target directors to offer incentives to bidders, the proposal recognizes that target shareholders benefit from negotiated transactions. The directors, as bargaining agents for the shareholders, should be able to obtain a better price than could the disparate shareholders responding individually to a hostile tender offer. ${ }^{362}$ Moreover, a no-shop covenant is a commodity with value. Ac-

holders with a "don't-approve" recommendation. But see ConAgra v. Cargill, 222 Neb. 136, 163-64, 382 N.W.2d 576, 592 (1986) (White, J. dissenting) (target board should have presented both offers and let the shareholders decide which offer was superior). The proposal, however, leaves such matters to basic contract doctrines. See, e.g., RESTATEMENT (SECOND) OF CONTRACTS, supra note 136, $\$ 261,265$ (discharge by supervening impracticability and by supervening frustration, respectively).

sso While bidder incentives are a major concern of those advocating the anti-auction rationale, our concern with such incentives should not be viewed as an implicit acceptance of the anti-auction premise. Instead, the proposed rule contemplates an auction even though it does, in certain circumstances, limit the form of the auction to a tender offer. See infra notes 354-55 and accompanying text.

ssi A no-shop covenant between the target and one bidder puts the competing bidder at a significant informational disadvantage. The negotiation process itself generates large amounts of information that is available to the primary bidder from no other source. See J. FreUnd, supra note 6, at 230-31; Gilson I, supra note 13, at 850 n.112 (citing J. Freund, supra note 6, at 230-31; J. McGaffey, Buying, Selling and Merging Businesses 13-32 (4th ed. 1979)). The favored bidders' informational advantage is partially dissipated after the initial bid is made public, given that a competing bidder can draw some conclusions from the amount of the initial offer.

352 A negotiated merger eliminates many of the potentially coercive effects of a tender offer for target shareholders. These coercive effects have been variously described as free rider problems, the "prisoner's dilemma game," and the "veto game." See Leebron, supra note 1, at 184-91, for an excellent description and evaluation of these theories as they apply to tender offers. Professor Leebron suggests that such bargaining constraints on target shareholders can make a tender offer a less costly acquisition process for the acquirer than a merger. Id. at 214-219; see also Bebchuck, Toward Undistorted Choice and Equal Treatment in Corporate Takeovers, 98 HARv. L. REv. 1693, 1708-33 (1985) (discussing the coercive effects of tender offers); Lowenstein, supra note 21, at 307-309 (same). Tender offer defensive tactics have been justified as a means of ensuring that target shareholders have access to the corporate bargaining machinery. See, e.g., Carney, Shareholder Coordination Costs, Shark Repellents, and Takeout Mergers: The Case Against Fiduciary Duties, 1983 AM. B. Found. Res. J. 341, 373-392 (discussing and evaluating certain defensive tactics that can function as 
quiring companies should theoretically pay more if such a covenant is a part of the merger agreement, and such additional consideration is of obvious benefit to shareholders. ${ }^{953}$ Part One of our proposal, by removing the directors' conflict of interest, obviates the need to offset these benefits against the costs of augmenting the power of directors who are not independent.

No-shop covenants do not impede the structural monitor because shareholders can, without penalty, reject the merger proposal. The existence of a no-shop covenant does, however, deprive the shareholders of one market alternative, namely competing merger offers. Competing bidders, in the face of a no-shop provision, are forced to operate through a tender offer directed at target shareholders. The issue thus becomes whether a tender offer is a sufficient market monitor of the target directors' merger recommendation. An affirmative answer to this question is compelled, subject to the limitation discussed below. Both auction and anti-auction proponents have championed the tender offer as the quintessential market monitor of the performance of target directors. $^{354}$ The tender offer, therefore, should be enthusiastically embraced as an effective monitor of the directors' decisions regarding the negotiated sale of the target company. ${ }^{350}$

Target directors can, of course, impede the monitoring effect of the tender offers by engaging in defensive tactics. A system allowing both no-shop covenants and an endless array of inventive tactics to defeat tender offers effectively eliminates the market monitor of the target

coordination devices to alleviate the coercive effect of two-tier tender offers); Oesterle, Target Managers as Negotiating Agents for Target Shareholders in Tender Offers: A Reply to the Passivity Thesis, 71 Cornei.. L. Rev. 53, 56-73 (1985) (discussing benefits available to target shareholders through managerial bargaining). Similarly, as noted by the Supreme Court in CTS Corp. v. Dynamic Corp. of Am., 107 S. Ct. 1637 (1987), recent state statutes that require a shareholder vote on a tender offer or prohibit two-tier offers remove many of the perceived coercive effects of tender offers. See id. at 1646, 1651; see also supra note 105.

${ }^{853} A$ contrary position is argued by Professor Buxbaum, who asserts that bidders will pay more for a contract with a no-shop constraint only if they suspect a more lucrative deal is imminent. Buxbaum, supra note 24, at 1705.

so4 See, e.g., Bebchuck I, supra note 70, at 24 ("All participants in this . . [auction/anti-auction] debate agree that management should be barred from obstructing tender offers."); Easterbrook and Fischel I, supra note 42, at 1169 ("The tender offer bidding process polices managers whether or not a tender offer occurs, and disciplines or replaces them if they stray too far from the service of the shareholders."); Easterbrook and Fischel II, supra note 70, at 1 ("A tender offer gives the shareholders a chance to go over the heads of managers and replace them."); Gilson I, supra note 13, at 844 ("The market for corporate control is the principal constraint on management self-dealing in important situations, and the tender offer is the only displacement mechanism which has the potential to effectuate that constraint.").

${ }^{385}$ See Bebchuck II, supra note 201, at 1041-46 (competing tender offers monitor management's bargaining performance in negotiated acquisitions). 
board's merger decisions. The two cannot coexist in any reasoned proposal designed to provide an objective standard against which to measure the board's decisions regarding the sale of the target. ${ }^{356}$ The recent decisions in Revlon and Hanson indicate an emerging judicial intolerance for such tactics in the for-sale setting. ${ }^{357}$ Reliance upon such decisions, however, with their differing and perhaps disingenuous rationales, is not for the faint of heart. The proposal, therefore, specifically requires directors of targets that are for sale to give all bidders a fair opportunity to compete. ${ }^{368}$ The proposal accomplishes this by (1) prohibiting the use of defensive tactics or the implementation of state statutes designed to deter a competing bid, ${ }^{368}$ and (2) requiring target directors to waive uniformly any preexisting repellant measures such as poison pills ${ }^{380}$ or state legislative protections ${ }^{361}$ that remain under their control. While the proposal otherwise regulates only friendly acquisitions, this slight incursion into the minefield of hostile tender offers is necessary to preserve the hostile tender offer as an effective market monitor of target directors' merger decisions.

${ }^{356}$ See Gilson I, supra note 13, at 850 ("Restricting management's role in a tender offer . . . validates the unfettered discretion given management with respect to mergers and sale of assets.").

${ }^{357}$ See Hanson Trust PLC v. ML SCM Acquisition Co., 781 F.2d 264 (2d Cir. 1986); Revlon, Inc. v. MacAndrews and Forbes Holdings, Inc., 506 A.2d 173 (Del. 1986); supra notes 84-104, 204-210, 216-223 and accompanying text (discussing Reulon and Hanson); see also Edelman v. Fruehauf, 798 F.2d 882 (6th Cir. 1986) (enjoining inter alia a no-shop covenant and cancellation fee provision that preempted the bidding process in favor of management's buying group).

s68 See Hanson, 781 F.2d at 282; Revlon, 506 A.2d at 184.

389 The term "defensive tactics" as defined in the rule does not include any disclosure directed to target shareholders even if such disclosure has a negative impact on a competing bid. Such disclosure, to the contrary, is required pursuant to Part Two, paragraph (c) of the proposed rule. See also Gilson I, supra note 13, at 867 (noting that "[b]y providing ... information, management facilitates shareholder comparison of the value of target securities with the value of the tender offer").

s60 Poison pills and related defensive tactics consist of various rights given to target shareholders to purchase additional target securities. See supra note 65. Many poison pill plans reserve to the target directors the right to redeem the rights at a nominal sum. While poison pills deter coercive takeovers, such redemption rights give target directors the flexibility to facilitate acquisitions in which they acquiesce. The proposed rule provides that target directors who retain such redemption rights must, if they exercise them, do so uniformly for all bidders. See, e.g., Revlon, 506 A.2d at 181 (the Revlon board resolved to redeem the note purchase rights in connection with any cash offer of at least $\$ 57.25$ per share).

S61 See supra note 105 (summarizing powers that target directors retain under state statutes to inhibit or encourage a particular tender offer). 


\section{Lock-Ups and Cancellation Fees}

\section{a. Definitions}

The proposed rule prohibits target directors from entering into a transaction or taking any action that constitutes a lock-up or cancellation fee without prior shareholder approval. Our proposal defines a "lock-up" as (1) a stock option or sale that would result in more than a $15 \%$ increase in outstanding target voting shares, or (2) a sale of or agreement to sell more than $15 \%$ of the target's assets. ${ }^{382}$ There is nothing magical about the $15 \%$ figure. It is, in fact, a compromise among three existing rules currently used to give content to the concept of materiality in other contexts: the $18.5 \%$ limitation imposed on listed companies by the New York Stock Exchange Rules; ${ }^{363}$ the $10 \%$ figure used to define "significant assets" under the SEG disclosure rules for current reports; ${ }^{364}$ and the $15 \%$ limitation recommended by the SEC Advisory Committee to govern stock options granted during a tender offer. ${ }^{365}$

The purpose of the percentage test is to provide a bright line to distinguish lock-ups, which unduly interfere with the structural and market monitors, from so-called "leg-ups," which, while granting a head start to the initial bidder, do not undermine those monitors. ${ }^{366}$ There is no doubt that as the magnitude, and thus the effectiveness, of a lock-up increases, there is a corresponding decrease in the effective

${ }^{362}$ Lock-up arrangements with shareholders are not included within the constraints of the proposed rule, due to our premise that lock-up decisions are the province of shareholders. See generally Nathan, Lock-Ups and Leg-Ups: The Search for Security in the Acquisitions Market Place, 13 INST. ON SEc. REG. 1, 12-18 (1982) (discussing shareholder lock-ups and the potential applicability of various state and federal laws to such arrangements).

${ }^{363}$ NEw YoRK STOCK Exchange, supra note $7, \S 312.00$, provides that shareholder approval is a prerequisite to the present or potential issuance of common stock or securities convertible into common stock that could result in an increase in outstanding shares of $18.5 \%$ or more. The requirement of shareholder approval applies to asset sales only if they accompany the issuance of stock and the combined value of the stock and assets exceeds $18.5 \%$ of the market value of the outstanding shares. Id. \$ 312.03(c). The American Stock Exchange has a similar rule which prohibits stock issuances in excess of 20\%. See American Stock Exchange, INC., AmERICan Stock EXCHANGe Company Guide $\S 713$ (1987).

${ }_{384}$ See Item 2 Instruction 4, Form 8-K Adopted by the SEC for Use in 1934 Act Filings Pursuant to SEC Release No. 34-21982, 4 Fed. Sec. L. Rep. (CCH) II 31,003, at 21,994 (1982).

${ }_{385}$ The SEC Advisory Committee on Tender Offers proposed that, during a tender offer, shareholder approval should be required for stock issuances representing "more than $15 \%$ of the fully diluted shares that would be outstanding after issuance." SEG TENDER OFFER REPORT, supra note 224, Recommendation 41, at 44. The Commission favors reducing this percentage to 5\%. See Statement of Commissioner Shad, supra note 224 , at 86,683 .

${ }_{386}$ See generally Nathan, supra note 362 (providing an in-depth discussion and practical illustrations of the two concepts). 
functioning of the structural and market monitors. For example, it can be argued that an option granting a bidder the right to purchase $8 \%$ of the target stock has little effect upon the shareholder vote or upon the activities of competing bidders. ${ }^{367}$ On the other hand, an option granting $51 \%$ of the target stock, by giving the bidder effective voting control, will predetermine the shareholder vote and eliminate the possibility of competing offers. ${ }^{368}$ The difficulty is to choose a percentage that both allows the target directors to provide reasonable incentives to bidders and permits the adequate functioning of the structural and market monitors.

In order to preserve the structural and market monitors, the proposal denies the target directors the unilateral power to agree to lockups or cancellation fees. This necessarily removes from the target directors the ability to use these devices as incentives to lure initial or competing bidders. We feel, however, that the leg-ups permitted by the proposal, especially when coupled with the informational advantage inherent in a no-shop provision, preserve sufficient incentives to attract bidders. $^{368}$ If one believes that the monitoring systems should be preserved, the only quibble must be with the percentage chosen to distinguish lock-ups from leg-ups, not with the theory itself. While not wed to the $15 \%$ figure, we believe that it approximates the appropriate percentage.

The proposal defines "cancellation fees" as any fees paid to a bidder in excess of reasonable expenses incurred in negotiations with the target. ${ }^{370}$ Expense reimbursement is a reasonable incentive for target

367 See, e.g., Smith v. Pritzker, No. 6342 (Del. Ch. July 6, 1982) (upholding the validity of $8 \%$ stock option), rev'd on other grounds sub nom. Smith v. Van Gorkom, 488 A.2d 858 (Del. 1985).

${ }^{368}$ See, e.g., Data Probe Acquisition Corp. v. CRC Information Sys., Inc., No. 92133-1983 (N.Y. Sup. Ct. Nov. 11, 1984) (invalidating a stock option permitting the favored bidder to acquire voting shares equal to $200 \%$ of the target's then outstanding shares).

${ }^{369}$ Consider, for example, the case of a stock option granted to a bidder to acquire $10 \%$ of the target stock at an attractive price. If no bidding war ensues, the bidder never needs to exercise the option. If a competitive bid necessitates the exercise of the option, the initial bidder, if the ultimate victor, can recoup the option expenses from the target treasury. Even if the competing bidder succeeds, the initial bidder can put the stock to the winner, often at a profit. Nathan refers to this phenomenon as the "heads I win, tails you lose" game. Nathan, supra note 362, at 20; see also Oesterle, supra note 30 , at 152-53 (recognizing the problems inherent in lock-up options and suggesting the use of leg-ups to entice potential bidders).

${ }^{370}$ Cancellation fees, unlike lock-ups, are not defined in the proposal with reference to a percentage test. The proposal, instead, defines cancellation fees as any fees in excess of reasonable expenses, such as legal and accounting fees, standby financing commitments, and related items. While an acquiring company must pay fair value for the assets or stock obtained through the exercise of a lock-up option, it pays no tangible consideration for a cancellation fee which is, in effect, a liquidated damages provision. 
directors to offer reluctant bidders. While such expenses can prove considerable, ${ }^{371}$ the specter of such a repayment commitment ordinarily will not impede competition or predetermine a shareholder vote. ${ }^{372} \mathrm{~A}$ substantial cancellation fee, on the other hand, can both foreclose competitive bids and take any real choice away from the shareholders. Shareholders faced with the choice of approving a merger or remaining shareholders in a company that must pay a formidable cancellation fee are likely to approve the merger. The prospect of such a payment will have a similarly negative impact upon potential competing bidders. While the courts have not been favorably impressed with such arguments, ${ }^{373}$ the proposal recognizes that a limitation on cancellation fees, like lock-ups, is essential to the preservation of the structural and market monitors. ${ }^{374}$

\section{b. Shareholder Approval}

The proposal sanctions lock-ups or cancellation fees if they receive shareholder approval. On one level, the proposal presents the issue of the desirability of standardized obligations versus private ordering. ${ }^{375}$ Such private ordering must be permitted under our basic premise of allowing director flexibility consistent with the operation of the structural and market monitors. ${ }^{376}$ Shareholders, as the protected group,

In this sense, a substantial cancellation fee is more pernicious than a lock-up. While a rule confining permissible cancellation fees to a specified percentage of target value would, no doubt, help to preserve the structural and market monitors, it seems an inappropriate transfer of resources from the target shareholders to the thwarted bidder. Such a percentage test, however, while not incorporated in the proposal, might be an appropriate limitation upon the amount of reimbursable expenses.

${ }^{371}$ See, e.g., Samjens Partners I v. Burlington Indus., Inc., 663 F. Supp. 614, 619 (S.D.N.Y. 1987) (target agreed to reimburse acquiring company expenses up to $\$ 25$ million); DMG, Inc. v. Aegis Corp., No. 7619, slip op. at 3 (Del. Ch. June 29, 1984) (target agreed to reimbursement of legal expenses up to $\$ 1.25$ million).

372 See Buxbaum, supra note 24 , at 1706,1712 \& n.180 (while severe cancellation fees should not be tolerated "[m]odest, appropriately defined liquidated damages clauses committing the company to pay legitimate expenses . . . should be acceptable").

${ }^{373}$ See, e.g., Friedman v. Baxter Travenol, No. 8209, slip op. at 4-6 (Del. Ch. Feb. 18, 1986) (plaintiffs faced "substantial obstacles" in demonstrating that a $\$ 300$ million dollar liquidated damages clause impermissibly infringed upon the shareholders' voting rights in a merger transaction).

374 See Buxbaum, supra note 24, at 1706 ("The thinly veiled aim of [lock-up and substantial cancellation fee agreements] is to prevent the shareholders from exercising their statutory right of rejection by making the costs so high that acceptance cannot fairly be characterized as a choice; rather, it is a foregone result dictated by the board's 'managerial' activity of granting these options or penalties.").

${ }_{370}$ A host of academic literature explores the theoretical boundaries of this debate, which need not be repeated here. For a recent and comprehensive survey, see Davis, supra note 13.

${ }^{376}$ On the other hand, by suggesting specific legislative rules, our proposal rejects the concepts of private ordering and ad hoc judicial review as the primary means of 
should have the authority to permit board actions that limit or predetermine shareholder choices. ${ }^{377}$

The proposal, in effect, treats lock-ups and cancellation fees as an integral part of the merger itself. The directors, in approving a lock-up or cancellation fee, are not making a business decision that such devices, viewed in isolation, benefit the target. The propriety of such decisions can be ascertained only with reference to the underlying merger. ${ }^{378}$ It is, therefore, appropriate to classify lock-ups and cancellation fees as essential merger terms subject to shareholder approval. The shareholder vote is, of course, the embodiment of the structural monitor of the board's decision. While a lock-up or cancellation fee impedes the market monitor, the shareholders, as the real parties in interest, can legitimately decide to trade the market choices for the bid tied to the lock-up or cancellation fee.

The mechanics of the shareholder approval process, however, mean that as a practical matter, lock-ups and cancellation fees will be useful negotiating devices only under limited circumstances. For example, one obvious drawback is that in order to evaluate the merits of a lock-up, the shareholders must know the proposed merger terms. If the lock-up is determinative, such as a stock option equivalent to $51 \%$ vot-

regulating corporate mergers. It has been argued that the flexibility of general standards makes them superior to specific rules which can be avoided or manipulated by corporate counsel. See, e.g., Garrett, The Limited Role of Corporation Statutes, in Commentaries on Corporate Structure and Governance 95, 101-102 (1970); Deutsch, The Mysteries of Corporate Law: A Response to Brudney and Chirelstein, 88 YALE L.J. 235, 237 (1978) ("[T]he clearer and more uniform a rule is, the more likely it is to be regarded as a formality that can justifiably be manipulated so long as compliance with its explicit formulation is maintained."); Gilson I, supra note 13 at 881-887. Other scholars, however, argue for more detailed rules, stressing the need for predictability in corporate transactions and guidance for corporate directors. See, e.g., Chirelstein, Towards a Federal Fiduciary Standards Act, 30 Clev. ST. L. Rev. 203, 20511, 216-17 (1976); Coffee, supra note 13, at 1264-65. We have earlier demonstrated that ad hoc judicial review utilizing general fiduciary duty standards has been an ineffective means of monitoring merger decisions by target directors. Specific rules are thus needed to ensure the effective operation of the structural and market monitors that can adequately police these decisions. Therefore, while the shareholder approval process allows modification of the proposal's ban on lock-ups and cancellation fees, the proposal otherwise posits specific rules to permit the effective functioning of the structural and market monitors.

377 See Davis, supra note 13, at 21 (noting that "[w]here the parties possess the capacity to make an informed and explicit modification of the law's standard-form deal to suit their particular needs, they should be permitted to do so," and that this kind of capacity "may well exist where the principal consists of a body of security holders participating in a market populated by institutions and other sophisticated investors").

${ }^{378}$ Professor Gilson also suggests that shareholder approval of lock-ups is necessary to preserve the role of the shareholder vote in a merger transaction as a check against target managers' self-interest. Gilson does not, however, distinguish in this regard between lock-ups and leg-ups. See R. GiLson, supra note 106, at 844-47. 
ing power, the shareholders might as well vote upon the underlying merger. If the lock-up is smaller in scale, however, the shareholders could still rationally approve the lock-up and withhold judgment on the supporting merger while awaiting a potential competing bid.

Another consequence of the shareholder approval requirement is that it limits the practical use of lock-ups and cancellation fees to acquisition settings that are not unduly time sensitive. For example, a target that is itself searching for a merger partner could offer such an incentive to an initial bidder. The disclosure required by the proxy solicitation to target shareholders should delineate the details, implications, and financial advantages or consequences of the proposal. If this disclosure does not trigger any competing interest, and the target shareholders favor the proposed lock-up or cancellation fee proposal, the transaction can proceed.

In the midst of any auction of the target, however, the short time limits imposed by the Williams $\mathrm{Act}^{379}$ would all but eliminate the opportunity to solicit shareholder approval for a lock-up or cancellation fee. We feel, however, that the proposal otherwise preserves sufficient incentives to bidders. Moreover, the de facto ban on lock-ups under these circumstances is a necessary trade-off for the preservation of effective monitors of board merger decisions.

\section{State Law Regulation}

Our proposal reflects our belief that state law, rather than federal law $^{\mathbf{3 8 0}}$ or a stock exchange rule,$^{\mathbf{3 8 1}}$ should govern the role of directors in

379 See 15 U.S.G. $\$ \S 78 \mathrm{~m}(\mathrm{~d})-(\mathrm{e}), 78 \mathrm{n}(\mathrm{d})-(\mathrm{f})$ (1982 \& Supp. III 1985)); see also 17 C.F.R. $\S 240.14(\mathrm{e})-\mathrm{I}(\mathrm{a})$ (1987) (tender offers must remain open for 20 business days).

${ }_{380}$ Professor Lowenstein has suggested that the Williams Act be amended to forbid the target of a hostile tender offer from engaging in certain defensive tactics without prior shareholder approval. Professor Lowenstein's proposal would cover transactions, including stock or asset lock-ups, which constitute a structural change in the target. His proposal further recommends that tender offers remain open for six months in order to allow a meaningful shareholder referendum. See Lowenstein, supra note 21, at 317-18. We applaud the notion of a shareholder vote and generally concur that tender offers should remain open for longer than the 20 days required by current regulations, see 17 C.F.R. $\S 240.14(\mathrm{e})-1$ (1987). Recent bills proposed in Congress would, if enacted, extend this time period. See, e.g., H.R. 2172, 100th Cong., Ist Sess. (requiring tender offers to remain open for 60 days). An amendment lengthening the Williams Act's 20day period would put tender offers on a more equal footing with negotiated merger acquisitions, which often take months to complete. Such an extension would be necessary to implement the proposals of other scholars who argue for greater shareholder participation in the implementation of defensive tactics. See, e.g., Siegel, supra note 27, at 409-12; Coffee, supra note 13, at 1261-64. With reference to our proposal, a Williams Act amendment would perhaps better enable target directors to make use of lockups in auction settings. We are not, however, especially troubled by the practical limitation on lock-ups which our proposal entails under current federal law. Professor 
mergers. Recent cases make it abundantly clear that disclosure is the

Lowenstein's proposal, moreover, which is explicitly limited to hostile transactions, would do nothing to regulate the activities of the target board during negotiated transactions. For additional criticism of Professor Lowenstein's proposal on the grounds that state, rather than federal, legislation should govern tender offer defensive tactics, see Siegel, supra note 27, at 399-400; see also supra note 105 (discussing state control share acquisition statutes, which have the effect of extending the time period that a tender offer must be kept open).

${ }^{381}$ In Great Britain, the City Code on Take-Overs and Mergers (1985) [hereinafter GITY CODE], a series of rules promulgated and enforced by a panel of investor, banking, and stock market groups, requires that if a tender offer is in progress or imminent, the target directors cannot, except in the ordinary course of business, issue additional shares or options to acquire additional shares or buy or sell significant assets unless pursuant to a preexisting contract. See CITY CoDE, supra, Rule 21, which provides in pertinent part:

During the course of an offer, or even before the date of the offer if the board of the offeree company has reason to believe that a bona fide offer might be imminent, the board must not, except in pursuance of a contract entered into earlier, without the approval of the shareholders in general meeting: (a) issue any authorized but unissued shares; (b) issue or grant options in respect of any unissued shares; (c) create or issue or permit the creation or issue of any securities carrying rights of conversion into or subscription for shares; (d) sell, dispose of or acquire, or agree to sell, dispose of or acquire, assets of material amount; or (e) enter into contracts otherwise than in the ordinary course of business.

The City Code, however, lacking the enforceability of a statute, depends for its enforcement upon the pressure which the panel members are able to bring to bear upon their peers. See DeMott, Current Issues in Tender Offer Regulation: Lessons from the British, 58 N.Y.U. L. Rev. 945, 955 (1983) (noting that "the Panel relies primarily on the coercive forces of adverse publicity and industry peer pressure" in enforcing its provisions). Professor Coffee has suggested a similar shareholder approval rule, utilizing the self-regulating New York and American Stock Exchanges as vehicles for promulgation and enforcement. See Coffee, supra note 13, at 1255-69. Professor Coffee himself delineates the enforcement problems which have plagued attempts at self-regulation through the Stock Exchange rules. These problems include: interpretation issues; limitations on sanctions, especially for disappearing targets; exchange bias in favor of listed companies; and the voluntary delisting by potential targets. See id. at 1256-58. For our present purpose, two major limitations suggest that such exchange rules would be insufficient to regulate lock-ups in negotiated mergers. First, the exchanges do not, and are not likely to, govern cancellation fees or asset lock-ups unaccompanied by stock issuances, see New York STOCK EXchange, supra note 7, § 312.00; American STOCK EXChaNGE COMPANY GuIDEs, supra note $363, \S \S 713-14$. The SEG has indicated that it does not favor exchange rules restricting asset lock-ups, stating instead that such matters should be governed under state corporate law. See Statement of Commissioner Shad, supra note 224 , at 86,683 . While this may indeed be "buck passing" by the SEC, as claimed by Professor Coffee, see Coffee, supra note 13, at $1261 \mathrm{n} .351$, it is unlikely that, without SEC prodding, the stock exchanges will include asset lock-ups within their rules. Second, while stock exchange rules may bind the largest publicly held companies, they do not apply to the great mass of small- or medium-size companies, which are more likely to be target companies. While large size in no way immunizes a company from target status, it is more likely that in a merger between a large company listed on a stock exchange and a smaller nonlisted company, the larger company will be the "acquiring company." Bebchuk I, supra note 70, at 28 (citing Singh, Take-Overs, Economic Natural Selection, and the Theory of the Firm: Evidence from the Post War United Kingdom Experience, 85 EcoN. J. 497 (1975)); see also M. 
primary purpose of the federal securities laws. ${ }^{382}$ Moreover, with the exception of the SEC proxy rules and the regulation of friendly tender offers under the Williams Act, federal law does not currently govern negotiated acquisitions. To suggest federal regulation at this juncture would counter the strong judicial and legislative trend towards state regulation. While state regulation of covenants in negotiated merger agreements presents traditional "race to the bottom" problems, ${ }^{383}$ such corporate governance matters are traditional state law concerns and should be regulated accordingly. ${ }^{384}$

\section{CONCLUSION}

In this Article, we have attempted to demonstrate problems endemic to negotiated corporate mergers under current statutes and judicial doctrines. While target shareholders must ultimately approve merger transactions, we suggest the need for effective monitors to police the ever-expanding role of target directors. Our proposal is designed to enhance the effectiveness of the structural monitor provided by the shareholder vote and the market monitor provided by competing bids. The independent director requirement eliminates the conflict of interest that can taint the directors' merger decisions and thus undermine the

EISENBERG, supra note 30, at 236 ("Indeed, it is ironic that almost all of the country's largest publicly held corporations are subject to [the Exchange Rules limiting the issuance of additional stock] while no comparable rule is applicable to the great bulk of small and medium-sized publicly held corporations, where it may be most needed.").

${ }^{382}$ See, e.g., Schreiber v. Burlington Northern, 472 U.S. 1, 8-12 (1985) (holding that the term "manipulative" as used in $\S 14(\mathrm{e})$ of the 1934 Act requires misrepresentation or nondisclosure and suggesting that the term "manipulative" should not be read as an invitation to the courts to oversee the substantive fairness of tender offers); see also, CTS Corp. v. Dynamic Corp. of Am., 107 S. Ct. 1637, 1644-48 (1987) (Indiana statute is not preempted by Williams Act, which is designed only to facilitate disclosure and establish procedural regulations governing tender offers.).

${ }^{383}$ The "race to the bottom" problem, so named by Professor William Cary, refers to the fear that states, interested in attracting corporate business, will not enact legislation limiting the powers of corporate directors. See Cary, supra note 164, at 66370; see also Louis K. Liggett Co. v. Lee, 288 U.S. 517, 557-64 (1933) (Brandeis, J. dissenting) (describing the historical evolution of lax state corporate statutes).

s84 See CTS, $107 \mathrm{~S}$. Ct. at 1650-51 (noting that merger regulations are a prototypical example of traditional state law concerns); Siegel, supra note 27, at 399-400; see also Note, Has Ohio Avoided the Wake of MITE? An Analysis of the Constitutionality of the Ohio Control Share Acquisition Act, 46 OHIo ST. L.J. 203, 220 (1984) (noting that states have a valid interest in the regulation of securities); Note, The Constitutionality of Second Generation Takeover Statutes, 73 VA. L. REv. 203, 216 (1987) (noting that the federal securities laws explicitly permit states to regulate securities); Note, Securities Law and the Constitution: State Tender Offer Statutes Reconsidered, 88 YALE L.J. 510, 520 (1979) (stating that it is inappropriate to infer that the Williams Act precludes state regulation in the absence of a dominant federal interest in securities regulation). 
operation of the structural and market monitors. Our proposal clarifies the role of the independent target directors in negotiating merger agreements and limits their authority to make decisions that would otherwise preempt the shareholders' role and unduly restrict the availability of competing bids.

Negotiated merger transactions will continue to dominate the acquisition arena in future years. The success of tender offer defensive tactics and state statutes inhibiting hostile takeovers should accentuate the increasing focus on negotiated acquisitions. Hopefully, our proposal will prove useful in the continuing effort to redefine the appropriate role of target directors in a merger transaction. 